\title{
LATE GOTHIC, RENAISSANCE AND MANNERISTIC FIGURAL SEPULCHRAL MONUMENTS IN MORAVIA AND CZECH SILESIA ${ }^{1}$
}

\begin{abstract}
The overview study summarises in an updated context the findings of a long-term research into sepulchral sculpture in Moravia and Czech Silesia, which dealt primarily with whole-figure sepulchral monuments, ranging from examples dependent on fading Central European late Gothic tradition, through examples gradually influenced by early Renaissance italianising elements up to such forms that were marked by Italian and Nordic Mannerism. Based on a comprehensive regional and broader Central European style-critical comparison, applying the criteria of contemporary artistic influences, individual creative approach, craftsmanship routine and other indicia important for a work to be done, the study presents the efforts to incorporate works into circles given by a specific author or workshops, or to highlight the provenience ties of solitary works.

The study shows that despite the enormous loss of sepulchral monuments that have occurred in the past, Moravia and Czech Silesia excel in its numerous production of figural tombstones, which demonstrate the ability of the monitored area to accept and operate with new humanist and representative content, and by the existence of which the local sepulchral sculpture reached specific expression. In addition to eschatological significance and private memorial function, the sepulchral monuments of nobility served also as a family policy, whereby the privileged strata confirmed the old tradition; which contained a personal, genealogical, confessional and political reminder.

Despite the selective character of the study, the processed material brings findings that can contribute to deeper understanding of the overall picture of sepulchral tomb sculpture of the monitored area as well as to its evaluation in the national and European context.
\end{abstract}

Keywords: sepulchral monuments, figural tombstones, sculpture, Moravia, Czech Silesia, late Gothic, Renaissance, Mannerism

Sepulchral monuments in Moravia and in Czech Silesia were in the past given only documentary and evidence-based attention. It was motivated by local historical, genealogical or heraldic interests. Miloslav Pojsl $^{2}$ summarised the history of inventory efforts in Moravia and Karel Müller ${ }^{3}$ in Czech Silesia. Unfortunately, the ambitious project of a monumental but unfinished synthetic treatise and an inventory of Moravian tombstones, including the dioceses of Olomouc and Brno by local history researchers Vítězslav

\footnotetext{
* Hana Myslivečková, doc., PhDr., CSc., Palacky Univerzity Olomouc, Czech Republic e-mail: hana.mysliveckova@upol.cz
}

Houdek and Augustin Kratochvíl, has remained unfinished. ${ }^{4}$ Miloslav Pojsl continued his systematic inventory documentation efforts. Of his ambitious plan for multi-volume edition of Monumenta Moraviae et Silesiae Sepucralia only the first part was dedicated to the oldest sepulchral monuments up to 1420, it was completed and published in 2006. ${ }^{5}$ In the second half of the twentieth century, the interest in sepulchral monuments gradually increased reflecting on their qualities and characteristics in artistic, semantic, confessional, and social context. From a number of partial treatises on individual objects or groups of works, it is fitting to mention here only some art-historical texts that brought at that time new and inspiring views on this type of works. Among others, these include an 


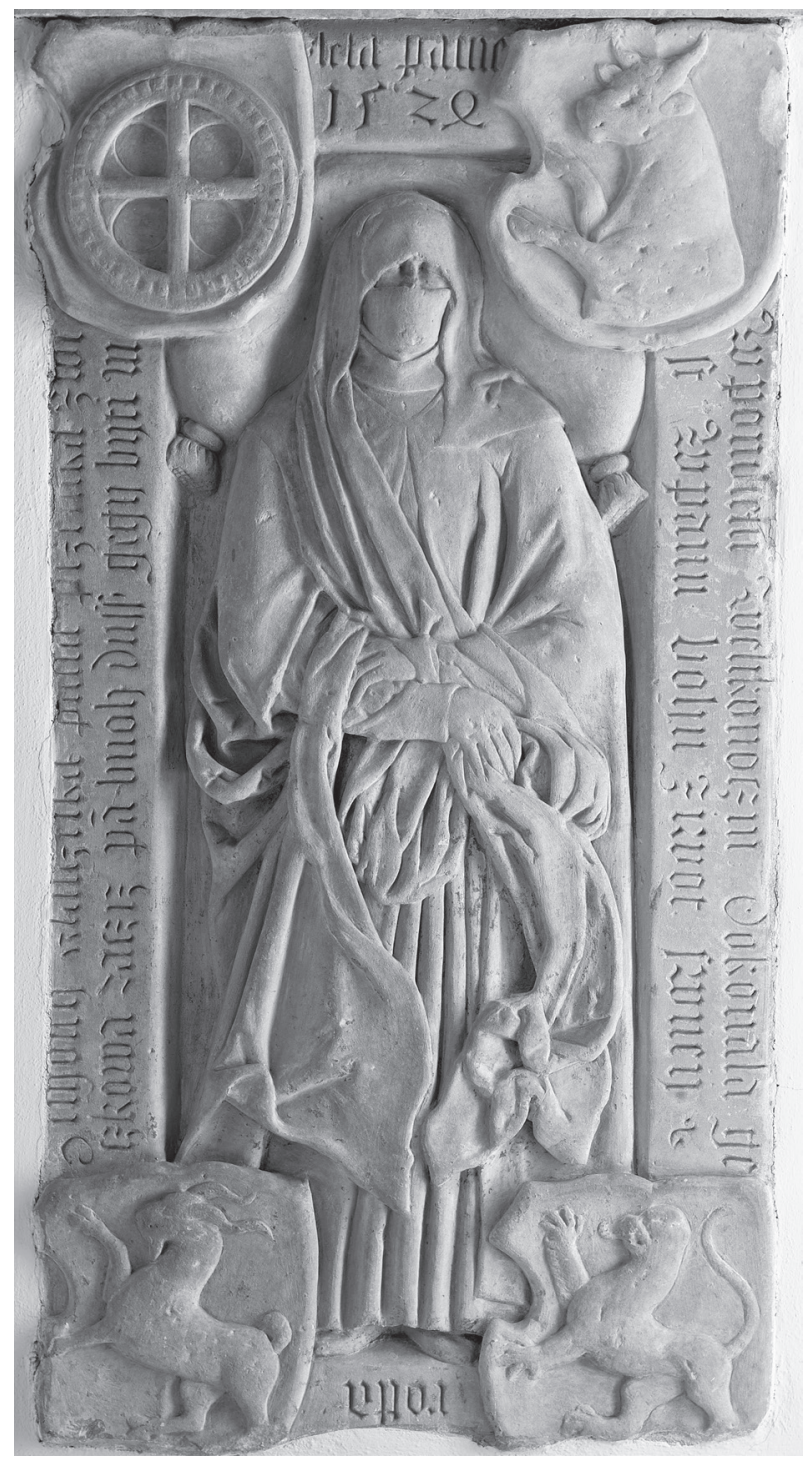

Fig. 1. Unknown master: tombstone of Dorota of Lhota (d. 1524), first wife of Přemek Prusinovský of Víckov, the valet of a lesser land right in Olomouc and the vice-chamberlain of Margraviate of Moravia. Prusinovice, Church of St Catherine (photo: Petr Zatloukal)

unpublished text by Miroslava Nováková6 and a study by Jan Chlíbec. ${ }^{7}$ Ivo Hlobil ${ }^{8}$ dealt with Late Gothic and Renaissance tombstones up to 1550 in the context of the study of humanism and early Renaissance in Moravia and later by the exhibition project From Gothic to Renaissance. Many other authors, namely Josef Maliva, Karel Müller have contributed to the issue with their partial observations while it was Ondřej Jakubec ${ }^{9}$ who has brought the study of epitaphs back to life.

The author of this study, who has presented the results of her long-term research in numerous journal studies as well as in the monograph titled Mors ultima linea rerum, Pozdně gotické a renesanční náhrobní

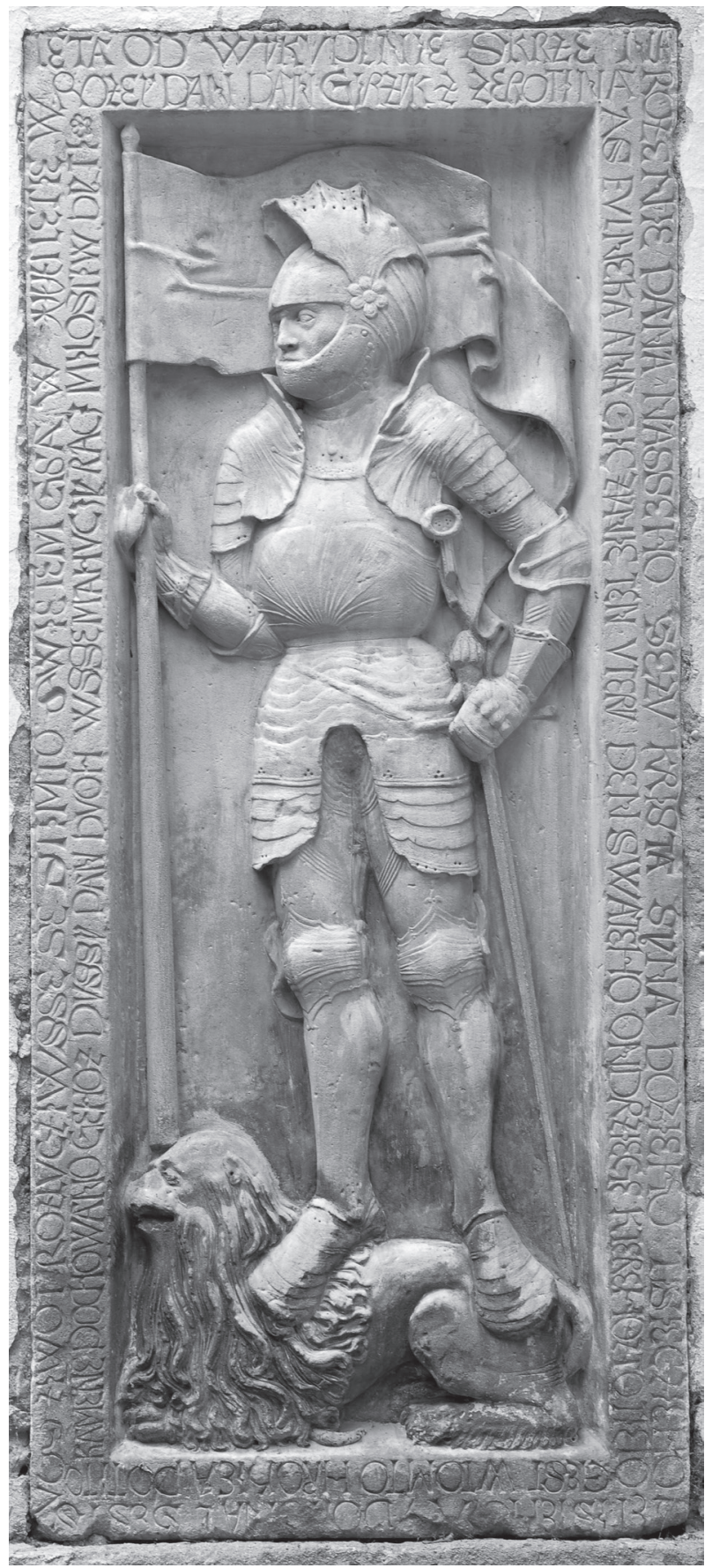

Fig. 2. Unknown master: tombstone of Jiří of Žerotín

(d. 1507). Fulnek, former Augustinian Church of Holy Trinity (photo: Petr Zatloukal).

monumenty na Moravě a v českém Slezsku [Late Gothic and Renaissance tomb monuments in Moravia and Czech Silesia], ${ }^{10}$ is also engaged in sepulchral work in the broader sense of the term. The attention paid to these artefacts was demanded by the fact that it was precisely in the sixteenth century, in connection with changes in the spiritual climate of the time, that the sepulchral monuments in Moravia and Czech Silesia 


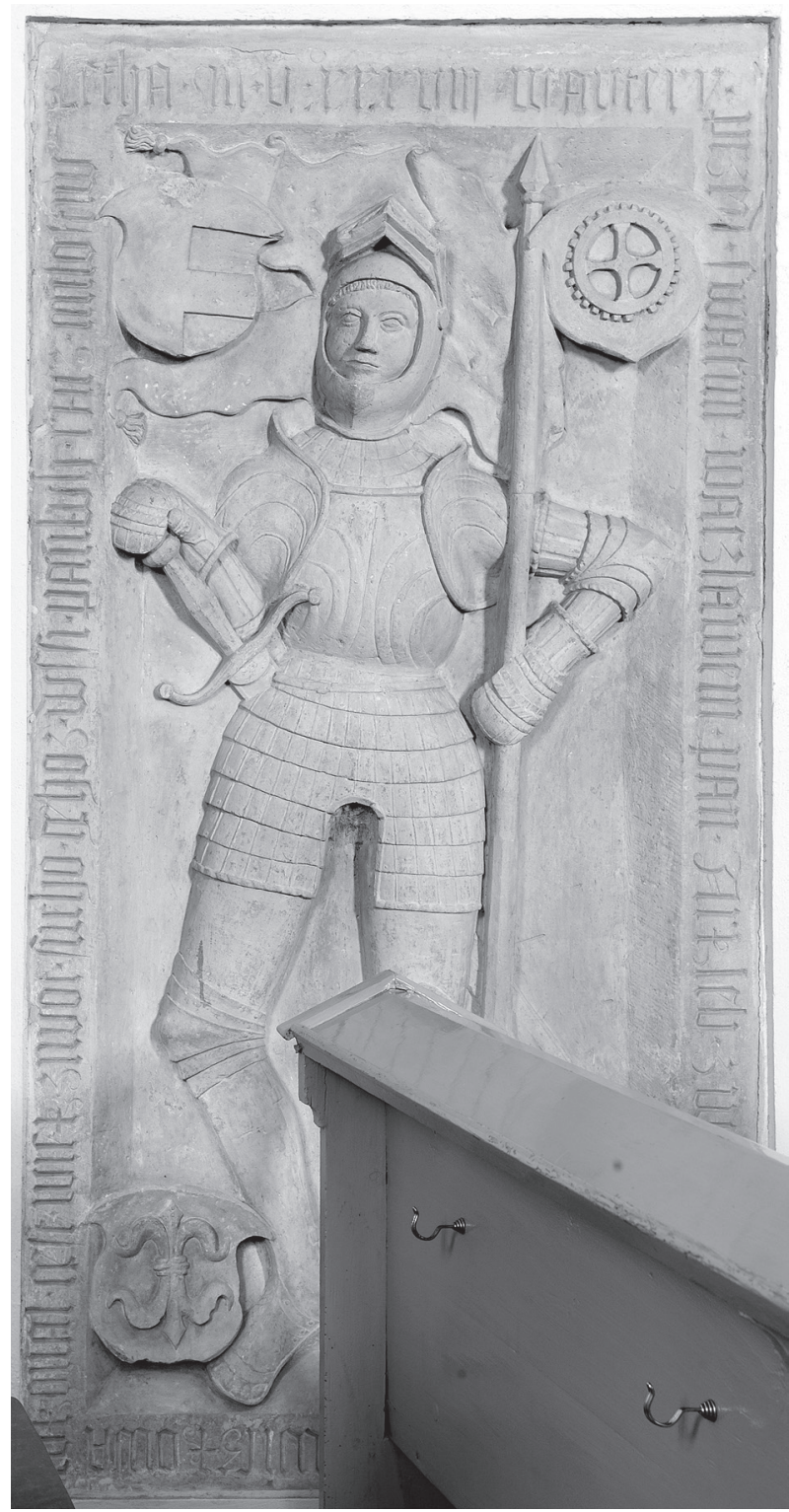

Fig. 3. Unknown master: Olomouc episcopal court circle, tombstone of Arkleb of Víckov (d. 1538), son of Přemek Prusinovský of Víckov, the valet of a lesser land right in Olomouc and the vice-chamberlain of Margraviate of Moravia. Prusinovice, Church of St Catherine (photo: Petr Zatloukal)

underwent unprecedented quantitative expansion and significant qualitative transformation. The abundance of Renaissance sepulchral monuments and the breadth of their phenomenon led to their typological limitation. It became a category, referred to as whole-figure sepulchres. Nevertheless, other monuments are mentioned in justified cases, such as semi-figural, heraldicinscriptions, or sculptural figural epitaphs. ${ }^{11}$

The narrower focus of the research allowed to concentrate more closely on the shifts of these works, on the path between tradition and innovation, that is,

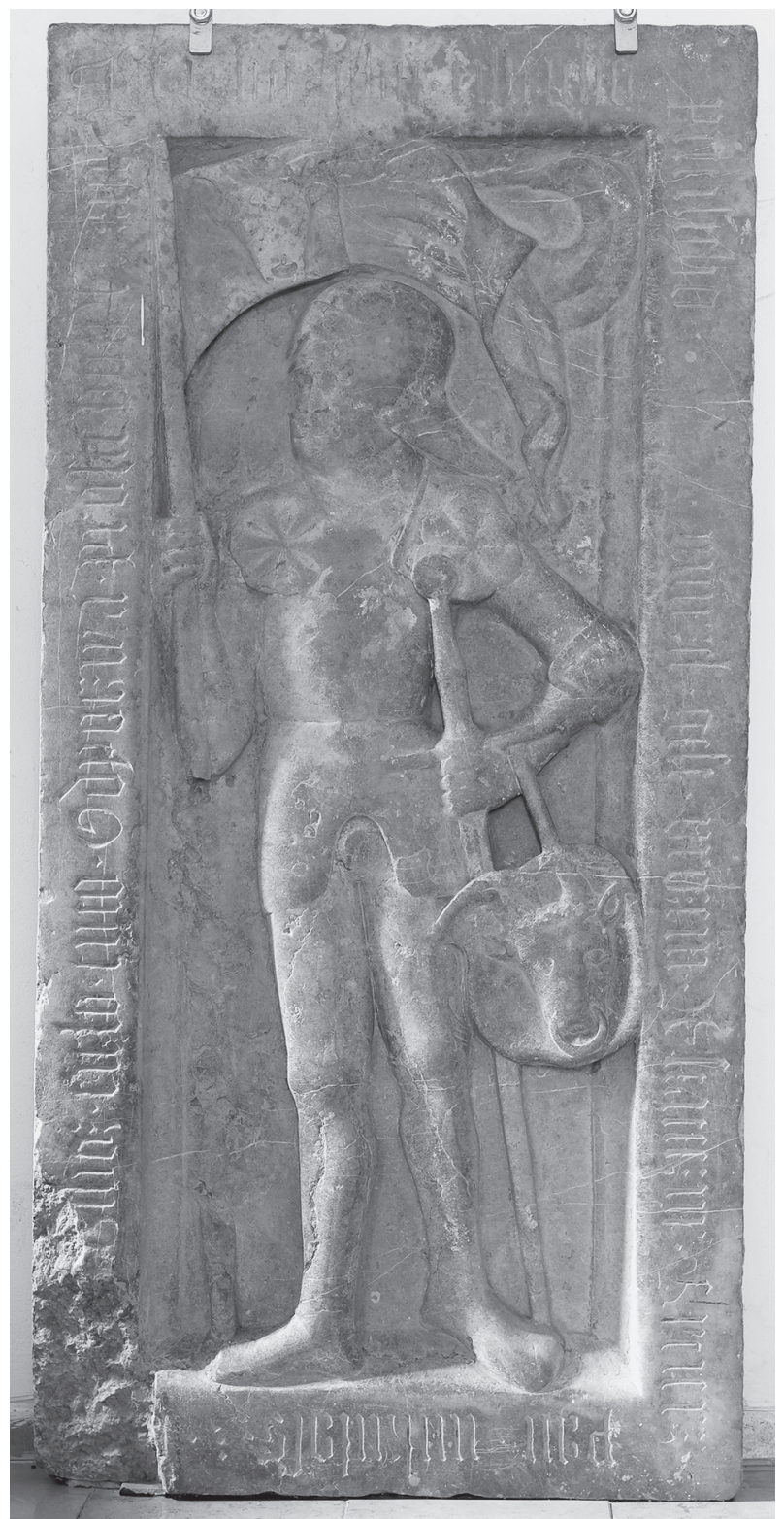

Fig. 4. Unknown master: tombstone of Mikuláš Hrdý of Klokočná (d. 1508 or at the beginning of 1509). Uherské Hradiště, Franciscan Church of Virgin Mary (photo: Petr Zatloukal)

on the way Moravian and Silesian tombstones differed typologically and stylistically from their examples that depended on the fading late Gothic tradition, through gradual influence marked by Italian and Nordic Mannerism, frequented mainly in the last third of the sixteenth century, and subsequently to their gradual retreat in the first quarter of the following century.

The preserved sepulchral monuments from the first third of the sixteenth century show only a gradual application of variously toned Italian motifs, influences and new craftsmanship ${ }^{12}$ that penetrated the 


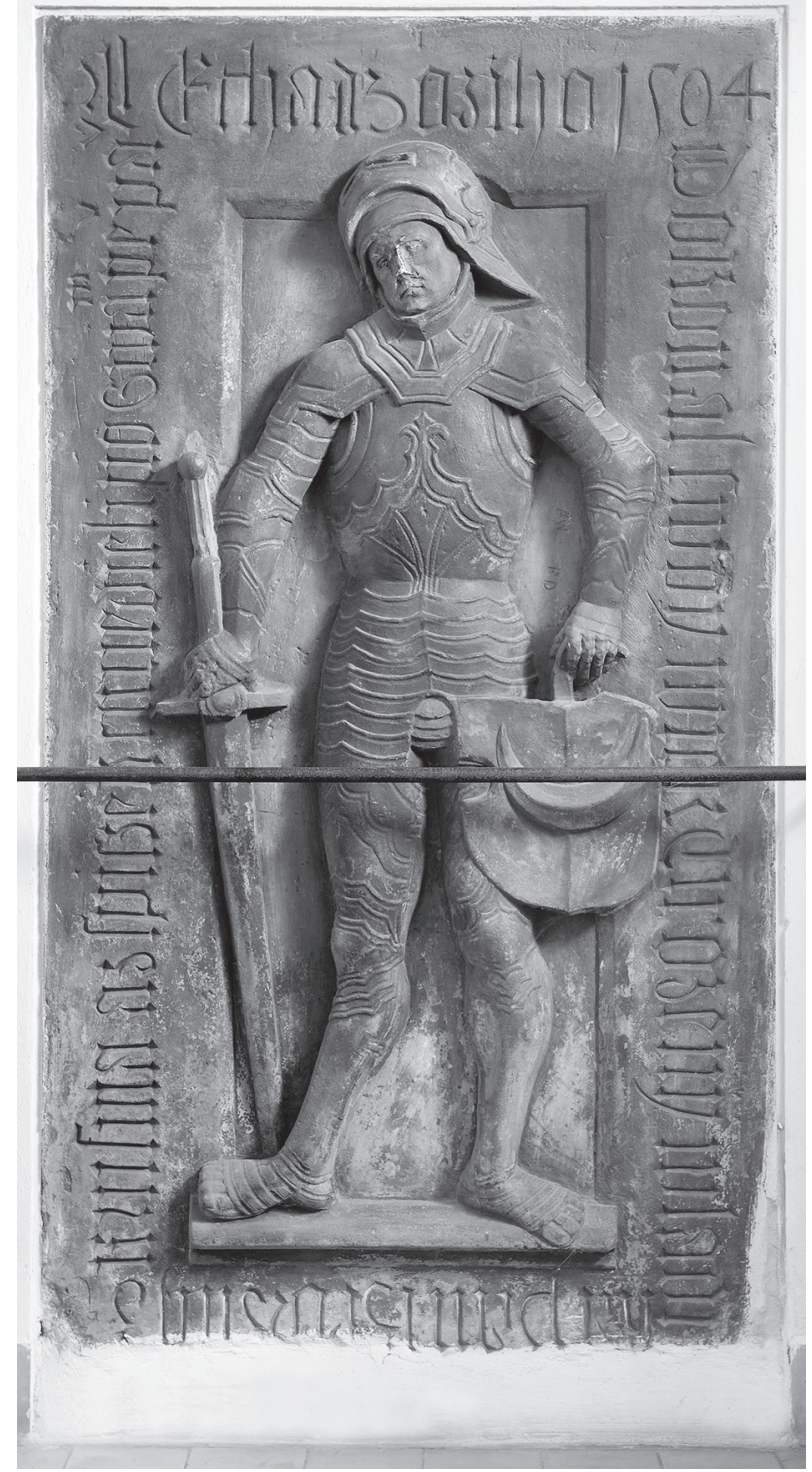

Fig. 5. Unknown master: tombstone of Bedřich of Krumsín (d. 1504). Bartošovice, St Peter and Paul Church (photo: Petr Zatloukal)

monitored area from the south through Hungary and also through important art centres of the Austrian and German Danube regions. Renaissance inspiration from Jagiellonian Poland later intervened not only through the Royal Court of Krakow but also through Silesia and had the greatest influence in the adjacent area of northern Moravia. Particularly intensive cultural and artistic contacts between the above-mentioned regions were conditioned not only by close relations between the bishoprics of Wrocław and Olomouc, but also by economic, commercial, territorial-administrative and, for a certain period, also by family ties. The cultural and artistic patronage efforts of Olomouc bishop Stanislav I Thurzo (episcopate / eps. 1497-1540) and his brother

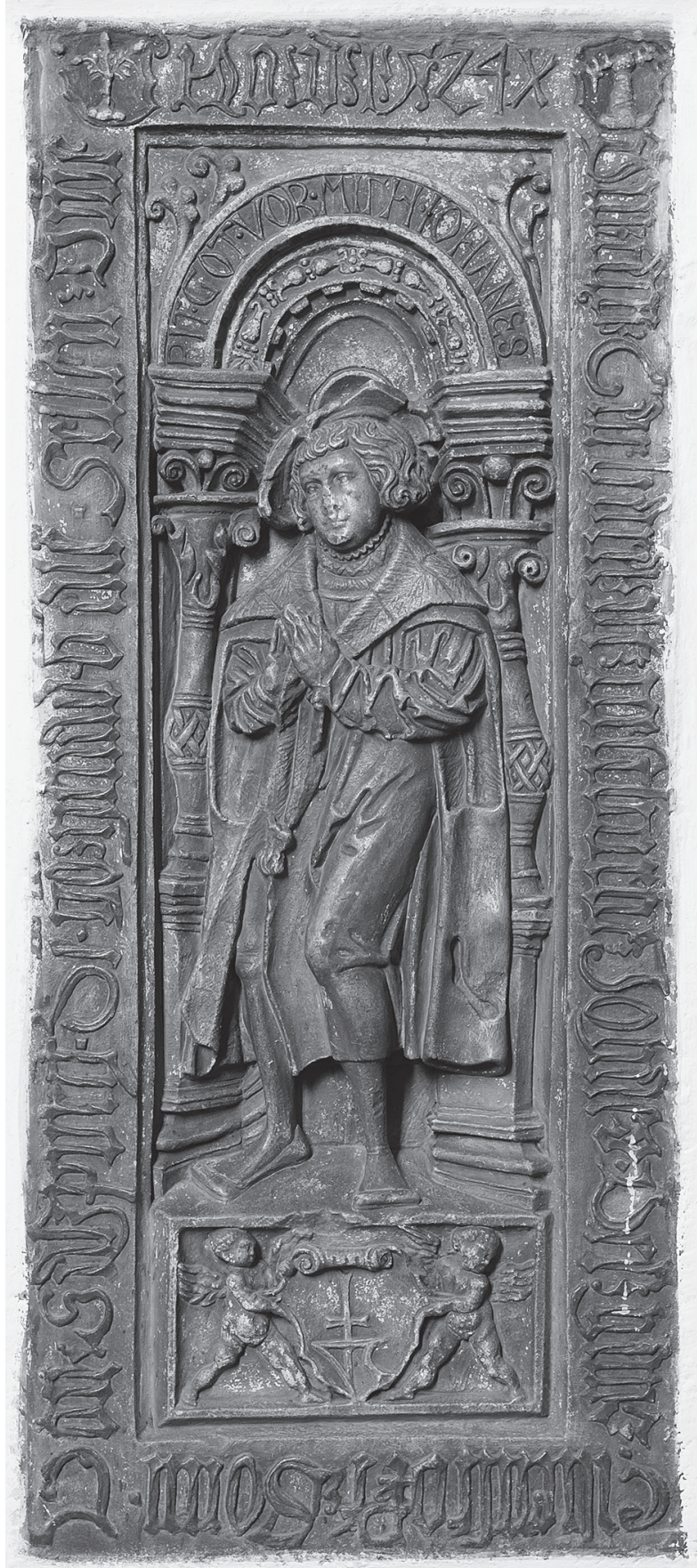

Fig. 6. Master of the Eibenstock epitaph: tombstone of Johann Eibenstock (d. 4. 12. 1524), the son of Hans Eibenstock, a Viennese merchant from Salzburg. Olomouc, Chapel of St Alexia at the cloister of Dominican Monastery of St Michal (photo: Petr Zatloukal)

Jan Thurzo, in the years 1506-1520 also as the bishop of Wrocław, are well known. These senior ecclesiastical dignitaries came from a noble-merchant family of Hungarian origin, who had a significant involvement in the mining business, and through direct business 


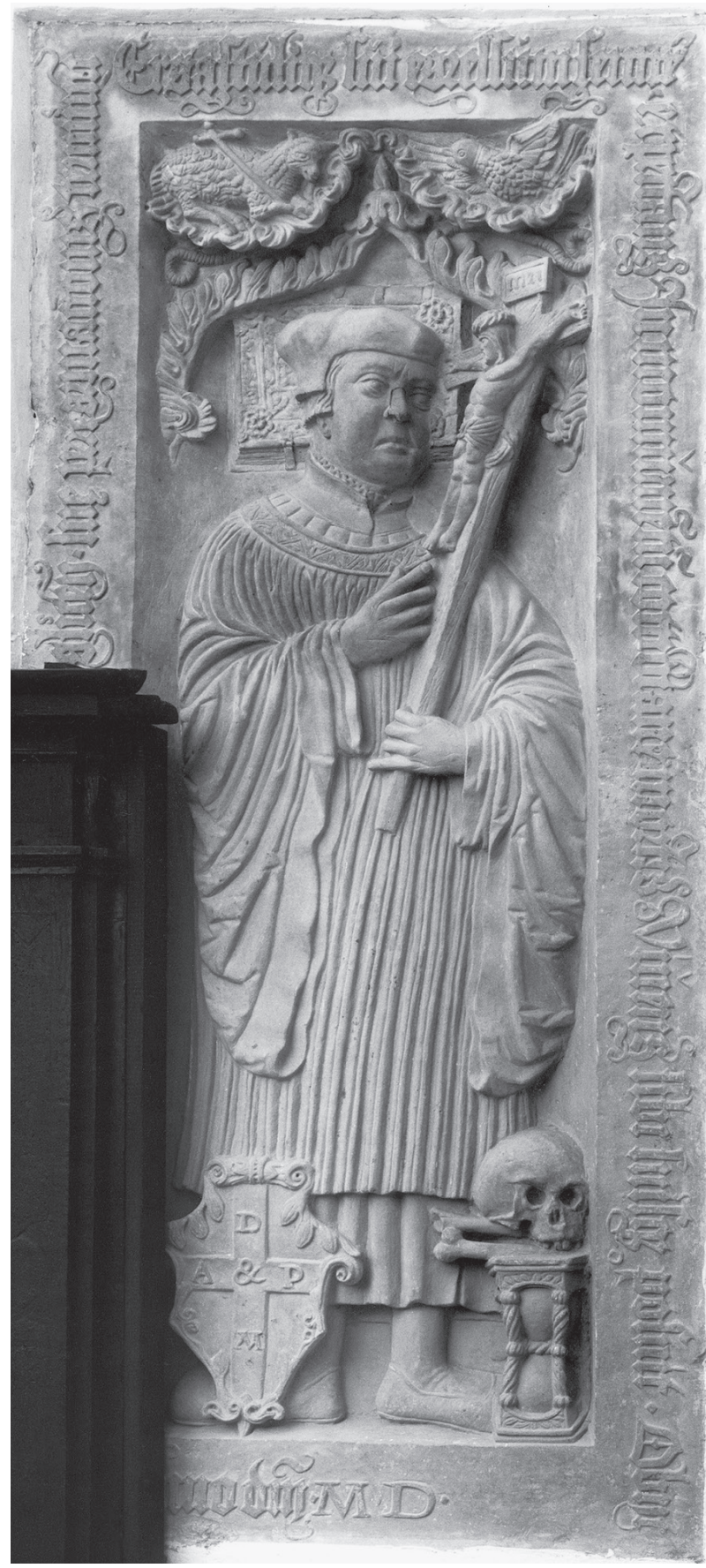

Fig. 7. Unknown master: Olomouc episcopal court circle, tombstone of Valentin Niger, a Mohelnice priest (made after 1530). Mohelnice, Church of St Thomas of Canterbury (photo: Petr Zatloukal)

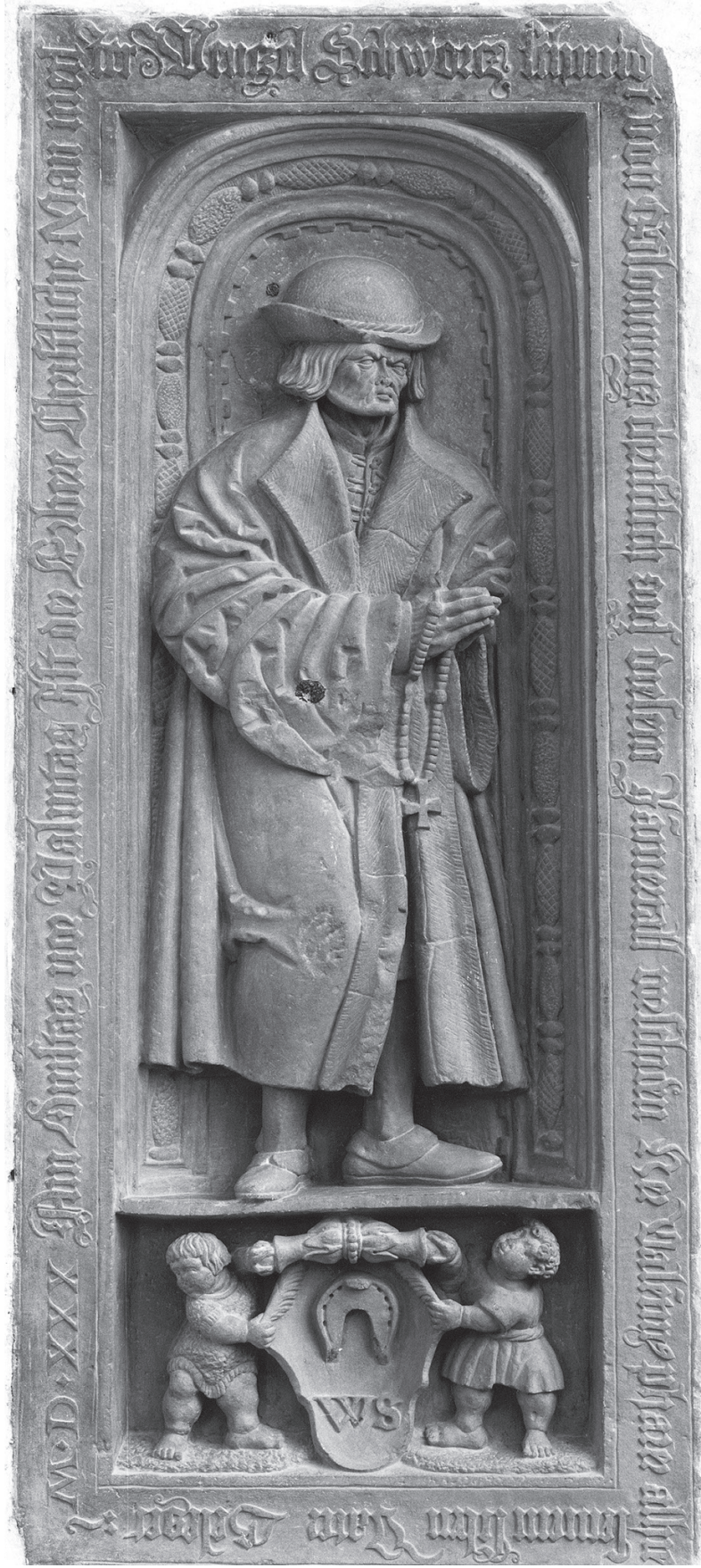

Fig. 8. Unknown master: Olomouc episcopal court circle, tombstone of blacksmith Václav Schwarz (d. 1530), the father of Mohelnice priest Valentin Niger. Mohelnice, Church of St Thomas of Canterbury (photo: Petr Zatloukal)

by the work of South German artists such as sculptors Jörg Gartner (around 1505 - after 1530), Loy Hering (1484/85-1554) or Stephan Rottaler (around 14801533), and so on. It is therefore possible to assume imports of their works, as evidenced, for example, by the epitaph of Spiš Count and royal dignitary Alexei Thurzo (d. 1543) in the church of St Jakub in Levoča, which were inspired by Italians, but clearly influenced 
who was rightly attributed to sculptor Loy Hering ${ }^{13}$ based on a comparative style analysis.

Given its geographical proximity, direct contact with Vienna also played an inspirational role. Thanks to contacts with the construction works engaged at that time with the St Stephen's Cathedral there was an exchange of builders, sculptors and stonemasons between the two areas, many of whom were not familiar with the Renaissance morphology. Some of the sights of the area suggest that the Italians also worked here, and that Vienna could have played a mediating role for Moravia and Silesia to be in contact with Northern Italian art. ${ }^{14}$ Italian influence intensified around the middle of the sixteenth century and came to us in various ways, often directly through more or less capable Wallachian creators, who were settling permanently in our cities and bringing the style of all'antica in a pure or mediated edition..$^{15}$ The liveliness of contacts with the regions of Saxony was related to the fact that many of the Saxon and Silesian builders and stonemasons were trained in the Prague late Gothic works of Benedikt Ried (1454-1534), ${ }^{16}$ who also worked with Renaissance morphology and whose range of effect was quite wide. ${ }^{17}$

The later withdrawal of the Italian models to the Dutch and their dissemination was related to the religious coups, where the Reformation led to a significant movement of population. The popularity of the Reformation movement, spreading not only in the middle class, but also in the aristocracy and initially enjoying considerable tolerance among the clergy, caused a shift in the artistic sphere towards the works of art centres of the German Reformation.

Since 1526, when Ferdinand I of Habsburg came to the Czech throne, Moravia and the adjacent Silesia became part of the extensive Habsburg Empire in Central Europe, which during the sixteenth century brought a significant expansion of artistic connections, which were based on contacts between the two Habsburg domains, Central Europe and Spain. This multi and international cultural and social atmosphere, which in our country reached its peak in the Prague court of Emperor Rudolf II of Habsburg (reign 1576-1611), naturally found a response in Moravian sepulchral work.

The diversity of the visual art of the last third of the sixteenth century was shaped not only by the influences of Italian but also Nordic Mannerism, which came to us from the Netherlands, through Saxony, Poland and Silesia, for example through the bishoprics Wrocław and Nysa, but also through OleĐnice and Brzeg ruled by the Piast dynasty.

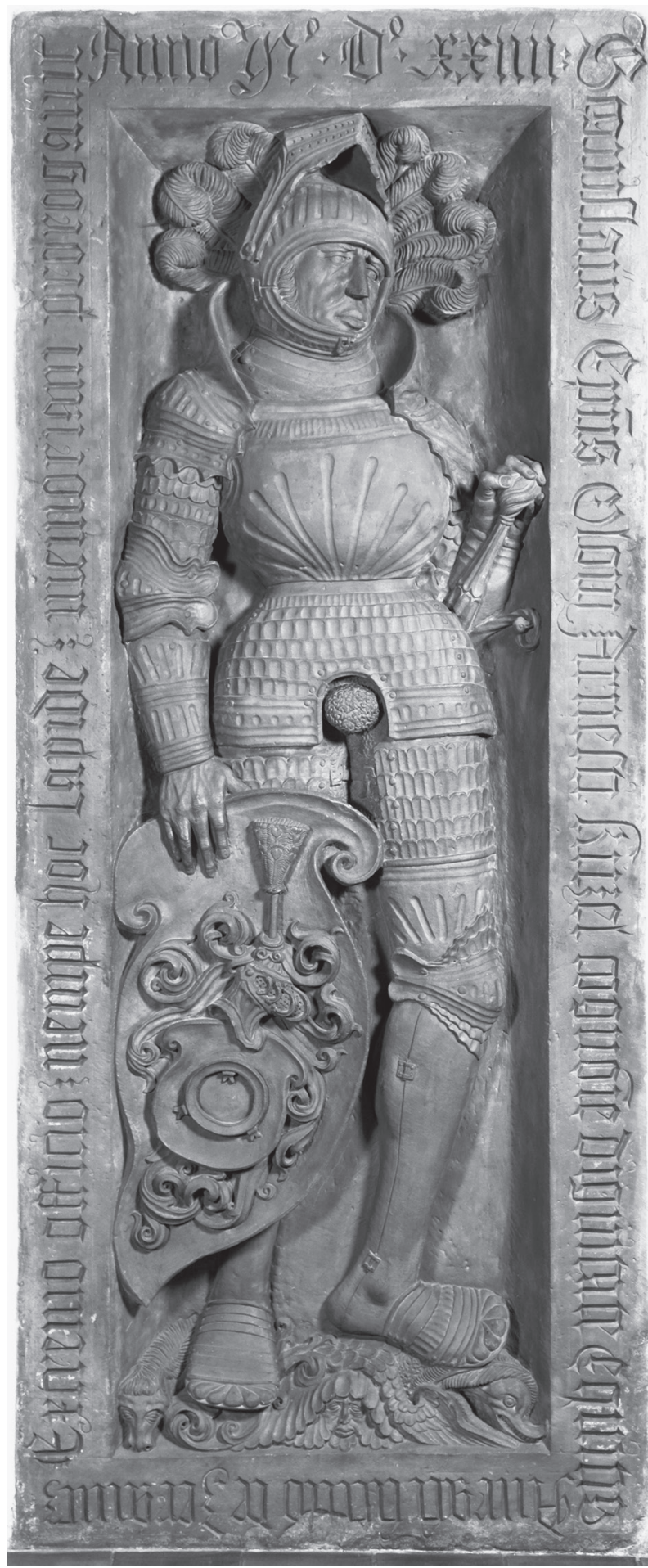

Fig. 9. Unknown master: Olomouc episcopal court circle, commemorative monument of Arnošt Kužel of Žeravice (d. 1508, dated 1524). Olomouc, Chapel of St John the Baptist at the cloister of the Cathedral of St Wenceslas (photo: Zdeněk Sodoma)

The spirit of international Mannerism, which, in addition to the increased interest in realistic aspects of depiction, favoured technical prowess, formal vir- 


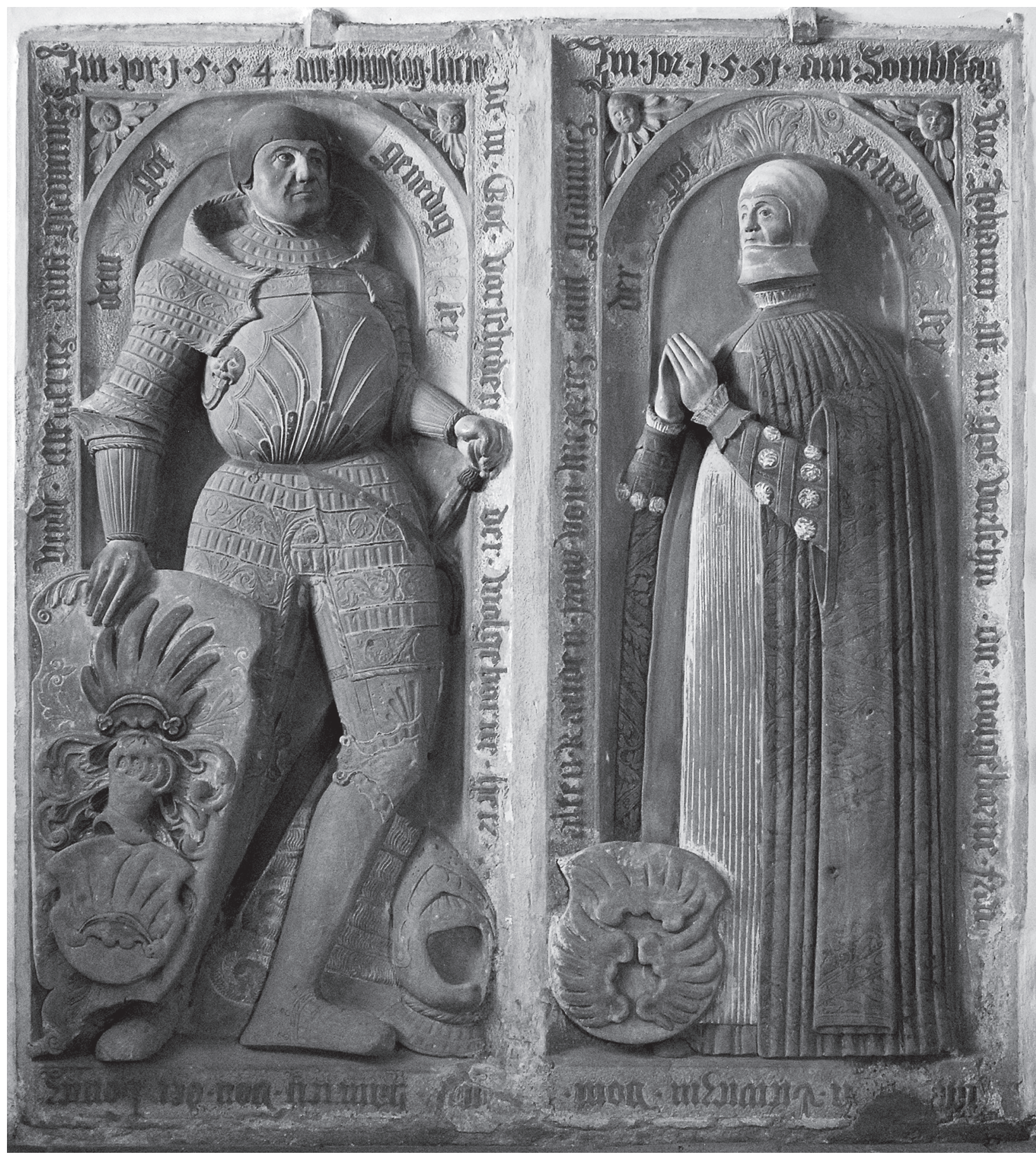

Fig. 10. Master H: tombstones of Jindřich of Lomnice and Meziřičí (d. 1554) and Anna Litvicová of Staré Roudno (d. 1551). Jemnice, Church of St Stanislav (photo: Hana Myslivečková)

tuosity, pomp, but also unnatural deformities. It had established itself either through artists themselves, through inspirational European examples or popular graphic designs and samplers made by Hans Vredeman de Vries, Virgil Solis, Cornelis Bose, Cornelis Floris, and others. Many motifs used by northerners were similar to the graphic art of Sebastian Serlio ${ }^{18}$ - among others - whose work was familiar to the Czech environment. ${ }^{19}$

The character of the sixteenth century sepulchral sculpture syncretically combines domestic late Gothic traditions with patterns of current stages of the Italian Renaissance and influences not only of Italian but also Nordic Mannerism. These often work concurrently, 
not allowing to clearly classify the presented sepulchral works or to draw coherent developmental lines of these works. Rather than the continuous development of sepulchral art, we can speak of transformations shaping the peculiar production of more or less independent sculptural-masonry circles genetically integrated with various areas of the Central European context.

The problem that we find difficult to deal with when studying Moravian and Silesian Renaissance tomb sculpture is that only a fraction of the original

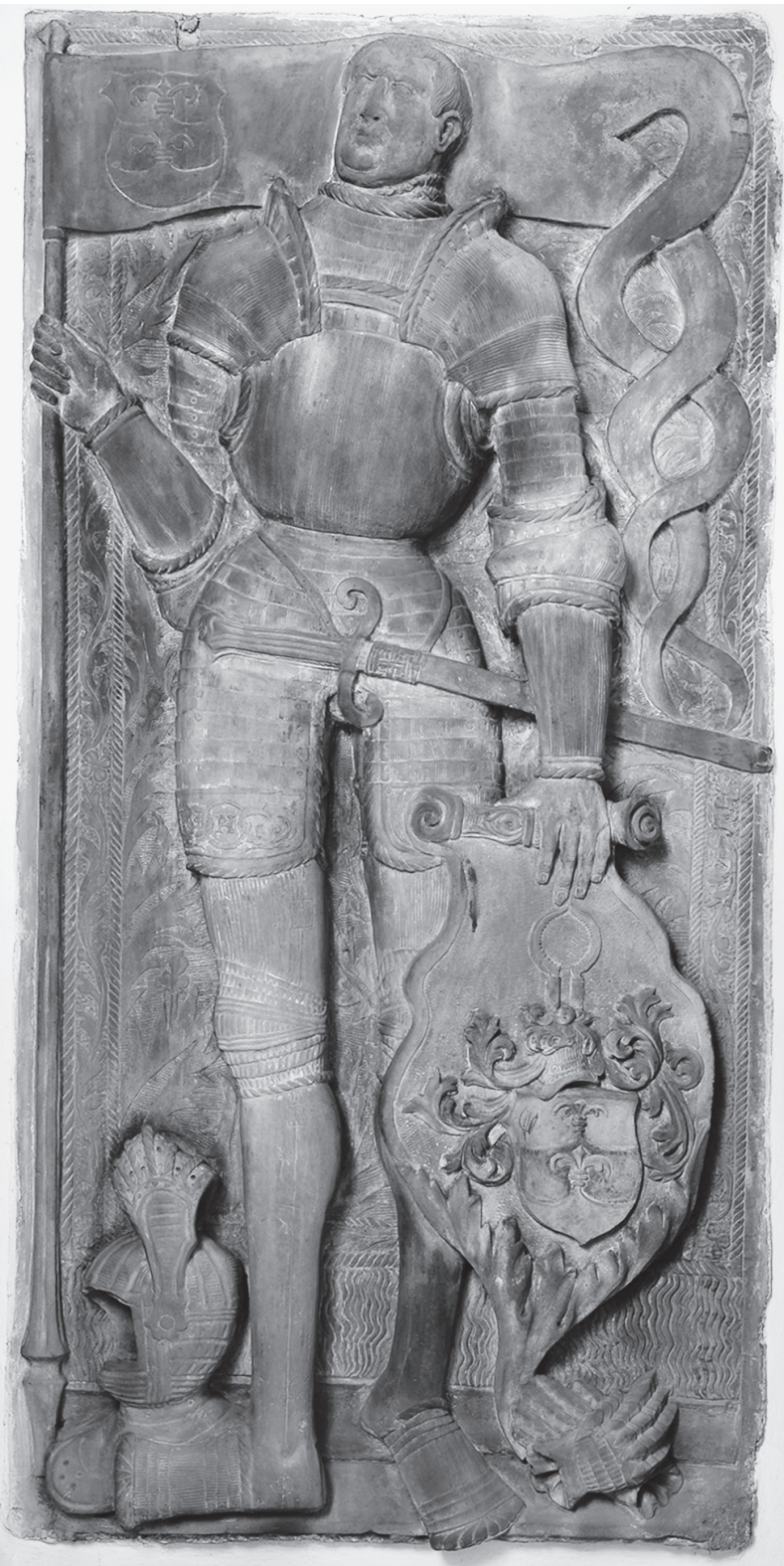

Fig. 11. Master PH: tombstone of Bernard of Zvole (d. 1536). Hlučín, Church of John the Baptist (photo: Petr Zatloukal) amount of sepulchral work of the late fifteenth and sixteenth centuries has survived. The enormous loss of monuments that occurred in the past is all the worse because they were important monuments, for example from the circle of the Olomouc Episcopal Court or from the parish and monastic churches of Moravian or Silesian royal and serf towns, which often had a model character. In particular, we refer to the surviving tombstones of the representatives of the Olomouc Diocese, whose existence is mentioned by contemporary sources. These include the tombstones of impor-

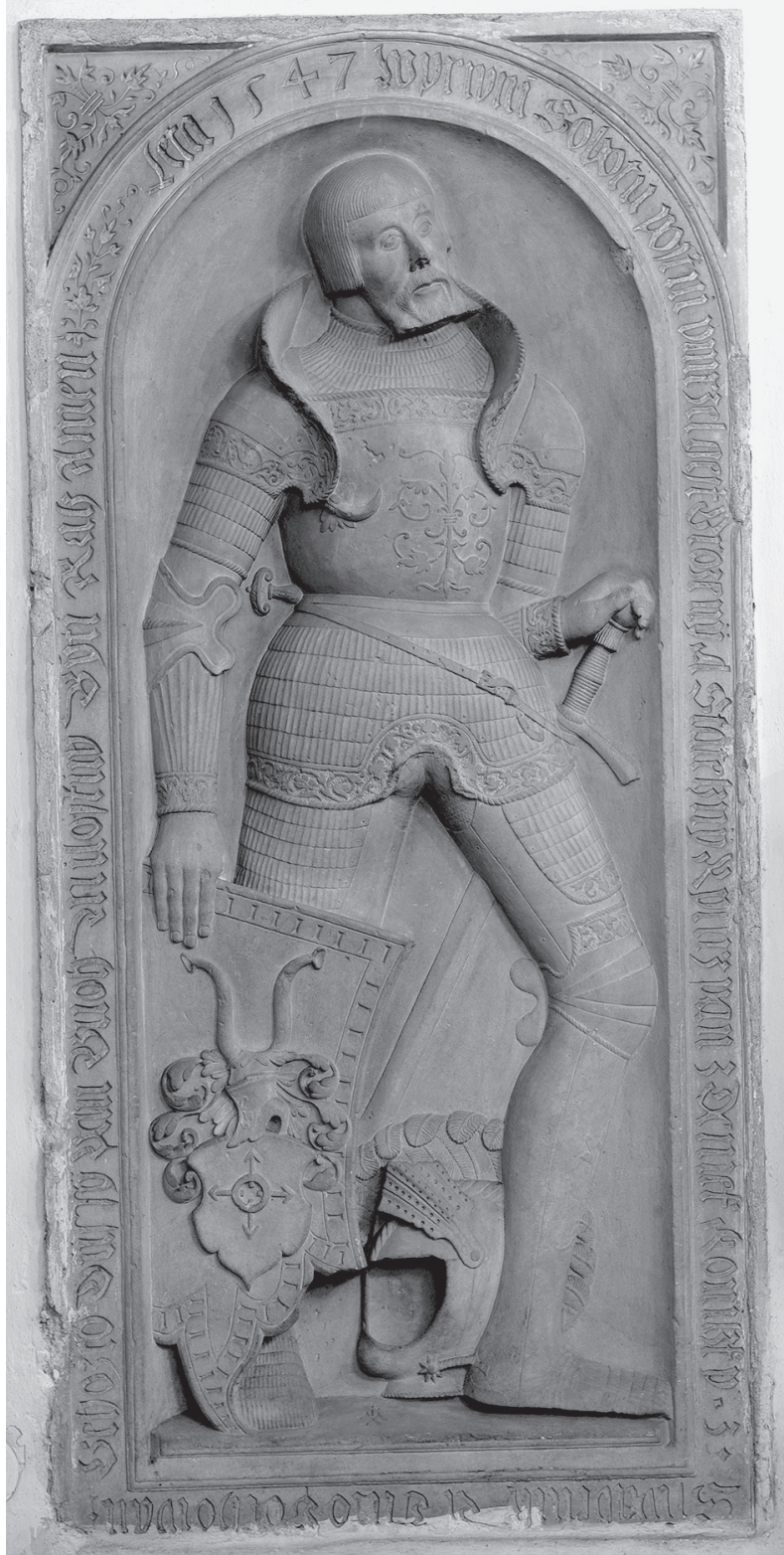

Fig. 12. Unknown master signed by stonemason's mark, belonging to the range of effect of Loy Hering: tombstone of Zdeněk Konický of Švábenice (d. 1547). Konice, Church of Nativity of the Virgin Mary (photo: Petr Zatloukal) 
tant Moravian personalities influenced by Renaissance humanism, not only by the local bishops, namely Tas of Boskovice (bishop 1457-1482, d. 1492), Stanislav I Thurzo (bishop 1497-1540, d. 1540), Bernard Zoubek of Zdětín (d. 1541), Jan Dubravius (bishop 15411552), but also canons such as Augustin of Olomouc (d. 1513) or Valentin Klementin Slavonínský (d. before 1529) and many others. ${ }^{20}$ However, despite this, the tombstone collection in Moravia and Czech Silesia is quite rich, formally and stylistically diverse, and exhibits a number of works of remarkable artistic quality.

In most cases, the question of authorship remains unresolved, which is largely due to the workshop ori-

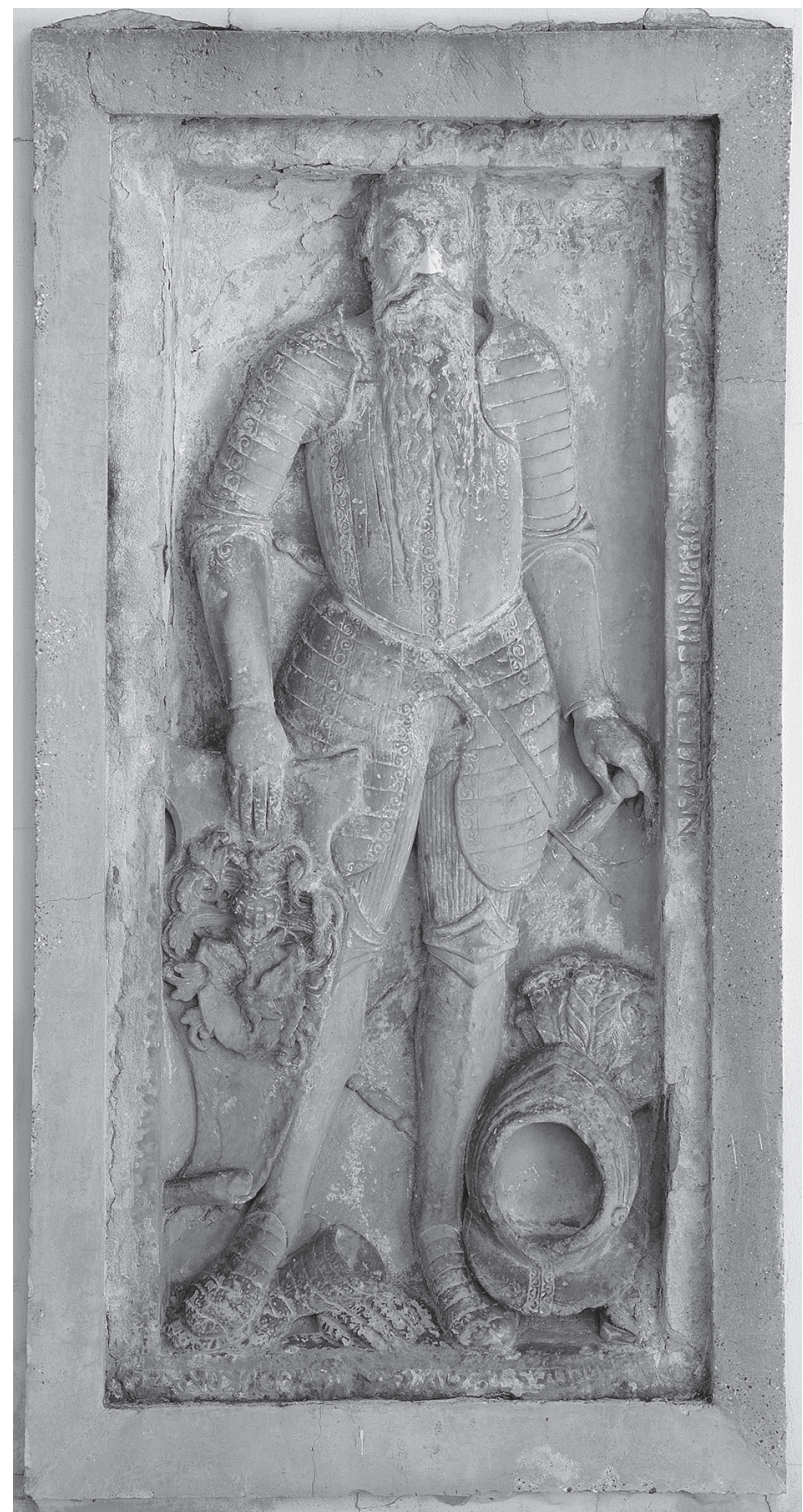

Fig. 13. Master of the tombstones of the Lords of Ludanice: tombstone of Václav of Ludanice in Chropyně (d. 1557). Rokytnice, Church of St James the Greater (photo: Petr Zatloukal) gin of the sepulchral monument, but also due to the fragmentary existence and the incomplete nature of information found in archival sources. We can read enough names of mason and sculptor masters, but we do not find the basis for us to attribute some of the preserved works. The tombstones rarely bear the

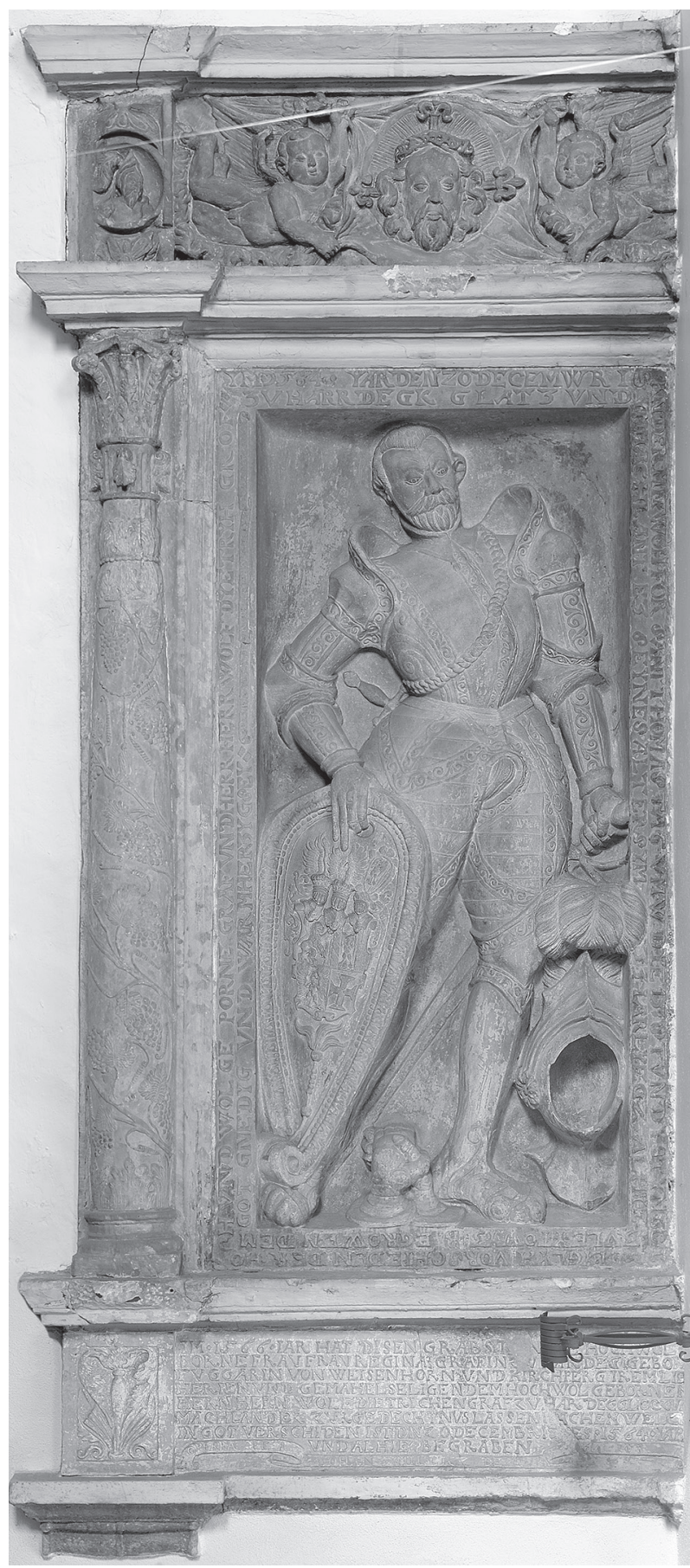

Fig. 14. Johannes Milicz: tombstone of Wolf Dietrich of Hardek (d. 1564, dated 1566).

Letovice, Church of St Procopius (photo: Petr Zatloukal) 
signature of the creator, either in the form of a stone mark or the name of the master, such as the sculptor Jan Milič. Some monograms or ligatures, especially $\mathrm{H}$ and $\mathrm{PH}$, which some authors considered to be stonemason's or sculptural signatures, ${ }^{21}$ give rise to doubts and legitimate assumptions that they are rather signatures of authors of graphic designs. ${ }^{22}$ And since it is not possible to proceed responsibly by name attribution, it was necessary to extract the maximum information directly from the preserved artefacts.

The above-mentioned facts were the main reasons for the applied concept of research and subsequent processing of the material, largely made available in the above-mentioned monograph. On the basis of critical comparative art-historical evaluation of preserved works, tracing their mutual filiations and in support of quite evident typological, stylistic and craft relatedness of numerous artefacts. Attempts were made to outline the creative profiles of several anonymous masters and their workshops to ascertain the typological and territorial extend of their work, and to learn about the social circumstances of the commissions they executed. So far, the survey has presented and critically reviewed about two hundred tombstones and other related artefacts preserved in Moravia and Czech Silesia and included them in consistent units. Almost twenty narrowly or broadly defined author or workshop circles whose work was of proven importance in the monitored area are included. At the same time, it also pointed out possible provenance connections of some solitary works. Comparative research was aided by the fact that authors varied their adopted register of typological, figural and ornamental forms, models and patterns. In the execution of the relief and its facture, in the implementation of the details it was possible to trace certain technical and manuscript stereotypes leading to the identification of workshops or authors named after the most outstanding or the highest quality works.

The tombstones of the area are mostly made of sandstones, dominated by the frequently used Maletín sandstone, which originates in Maletín in the episcopal estate in Mírov. However, there are also other sandstones, such as Mladějovský or Boskovice, in Silesia it is Těšín sandstone, sometimes also Kladský sandstone, the transport of these materials over longer distances was usual. Marble sepulchrals appear quite rarely, usually made from white marble from Nedvědice (also called Pernštejn), in Silesia it was the marble from Supíkovice. Unfortunately, the conclusions of the research cannot be supported by a systematic petro-

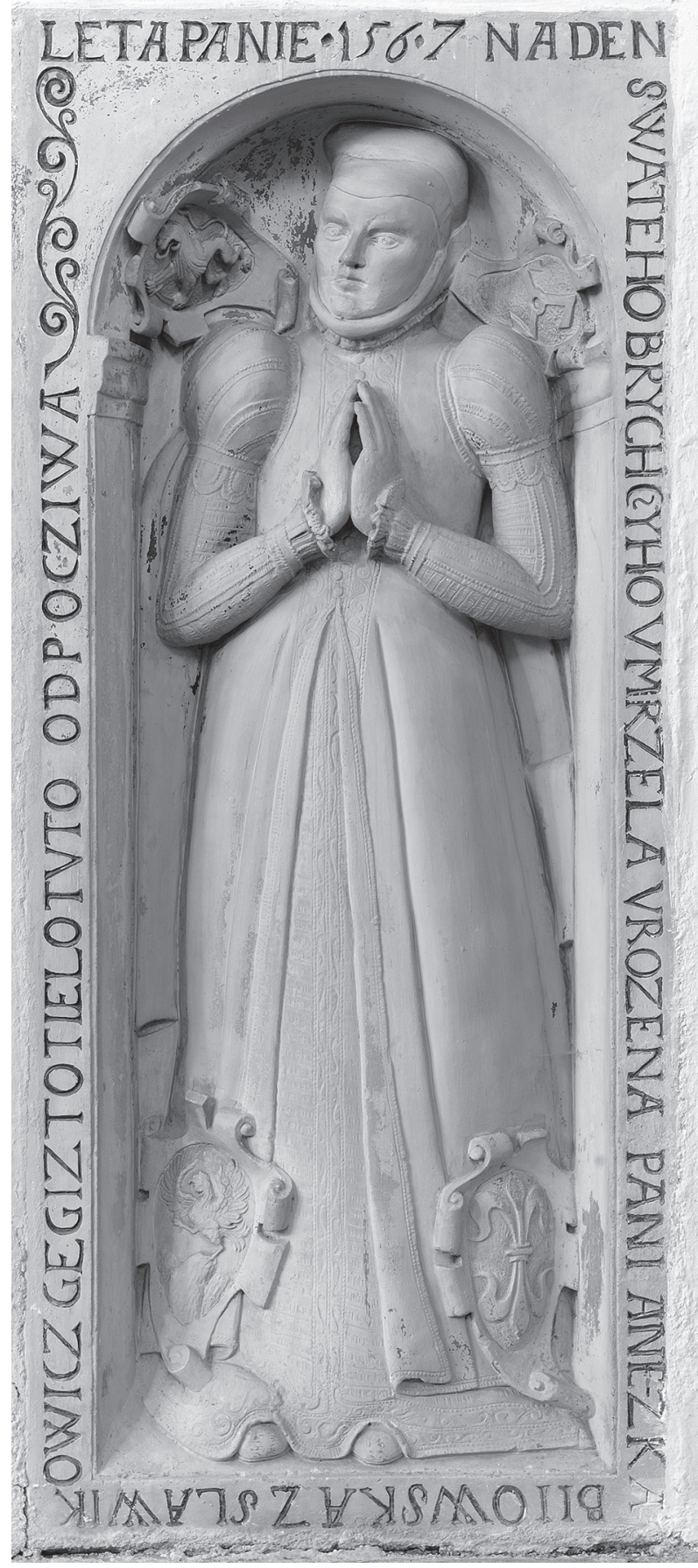

Fig. 15. Master of the Moravičany tombstones: tombstone of Anežka Bítovská of Slavíkovice (d. 1567).

Moravičany, Church of St George (photo: Petr Zatloukal)

graphic analysis of the material used, as the prepared research plan was not implemented due to the absence of institutional support (GAČR grant of the Czech Science Foundation). However, petrographic analyses are carried out as part of partial restoration interventions. Determining stone outside the scope of restoration interventions is often difficult, because in addition 
to the traces of the original polychromy, many tombstones carry repetitive paints of dark colours, which were supposed to imitate the rare dark red marbles used in Hungary or Austria. At the end of the sixteenth century, we not only encounter more frequent alternation of various, sometimes differently coloured materials, but later also the use of stucco components.

The collection of Moravian and Silesian medieval figural sepulchres has been documented by material artefacts since the end of the thirteenth century. However, a rather sparse group of gravestones with figures linearly carved in from the fourteenth and fifteenth centuries has not been completely processed yet. ${ }^{23}$ Late Gothic relief figural tombstones from the turn of the fifteenth and sixteenth centuries, preserved solitarily, show such a diversified style and quality and a variety of inspiration that we usually do not find closer analogies between them (Figs. 1-3). The exceptions are tombstones related by authorship, it is the marble tombstone of Kroměříz episcopal governor Mikuláš Hrdý of Klokočná (d. 1508 or 1509) in Uherské Hradiště (Fig. 4), and the tombstone of Bedřich of Krumsín and of Špičky (d. 1504) in Bartošovice (Fig. 5). The latter tombstone bears one of the oldest surviving Czech inscriptions that can be seen in the Moravian tombstone production of the early sixteenth century. The quantitative increase in the figural sepulchral monuments and their greater typological variation can be observed in the second and third decades of the sixteenth century. This is indicated by the works of the so-called Master of the Eibenstock epitaph ${ }^{24}$ (Fig. 6) and its connection with the stylistically advanced Mohelnice sepulchres, with tombstones and epitaphs of family members - father, mother and sister - of the local priest and altar of the Olomouc episcopal church, Valentin Nigr (Schwarz) from around 1530 (Figs. 7-8).

There is no doubt that the Olomouc episcopal court at the time of the episcopate of bishop Stanislav Thurzo (eps. 1497-1540), an active humanist inclined to new artistic tendencies, represented an important cultural centre of the country. That attracted not only goliard artists but also created conditions for forming local workshops. The significance of the development of the early Renaissance figural sepulchral production of the Olomouc region of the 1520 s and 1530s, referred to as the range of effect of the Olomouc episcopal court, rightly presupposes links to important contemporary sepulchral centres with mutual influence in the Bavarian and Austrian region around the Danube. ${ }^{25}$ However, a minimal number of preserved artefacts does not allow the formulation of more specific conclusions. An important role in the early works of this circle was played by the solemn work of the Olomouc commemorative monument of Arnošt Kužel of Žeravice (d. 1508, made in 1524), in the Chapel of St John the Baptist at the cloister of the Cathedral of St Wenceslas (Fig. 9). This monument, commissioned by bishop Stanislav Thurzo, is clearly embedded in the late Gothic sepulchral production of the Bavarian-Austrian Danube region. The closest inspirational analogies to this sepulchre can be found in the work of sculptor Stephen Rotaller (d. 1533?), a representative of the early Renaissance in Bavaria, ${ }^{26}$ as well as in the very important sepulchral monuments of Alexander Leberskircher (d. 1521) in Gerzen, or of Hans Klosen (d. 1527) in Armstorf. The closeness of the Rottaler-style gravestone of Werner von Messenbach (d. 1518) in Taufkirchen an der Pram, Upper Austria, also shows a similarity of this kind. ${ }^{27}$ This sepulchral monument seems to be a possible typological link between the memorial of Arnošt Kužel of Žeravice and the works of the Master of the Eibenstock epitaph and the sepulchrals of Mohelnice.

The commemorative memorial of the knight Arnošt Kužel of Žeravice inspired the motif of the works of another master, more influenced by Renaissance, and consensually referred to as Master $H$, who adopted and developed a similar scheme of figure representation. Although he tried to differentiate threedimensionally the spatial relations between figural motifs and the framing area for which simple architectural structures and decorative elements have become a commonplace (Fig. 10). ${ }^{28}$ Approximately eighteen sepulchres, which were created in the period between 1530s and the middle of 1560s can be currently attributed to the workshop of the so-called Master H. His working place is assumed to be in Olomouc, although it also worked for the Moravian nobility not only in South and North Moravia, but in Silesia as well. From the 1530s the work of the so-called Master PH attracts attention by the inclination toward the Renaissance morphology, toward more advanced typological concepts and especially toward the innovative processing of the relief, raised above the base plate (Fig. 11). Given that the supposed centre of activity of the above-mentioned authors was undoubtedly tied to the humanistic-Renaissance environment of the Olomouc episcopal court, closer working contacts between the two masters can be expected in the 1530s.

In addition to the activities of anonymous wandering and migrating artists who left solitary works 


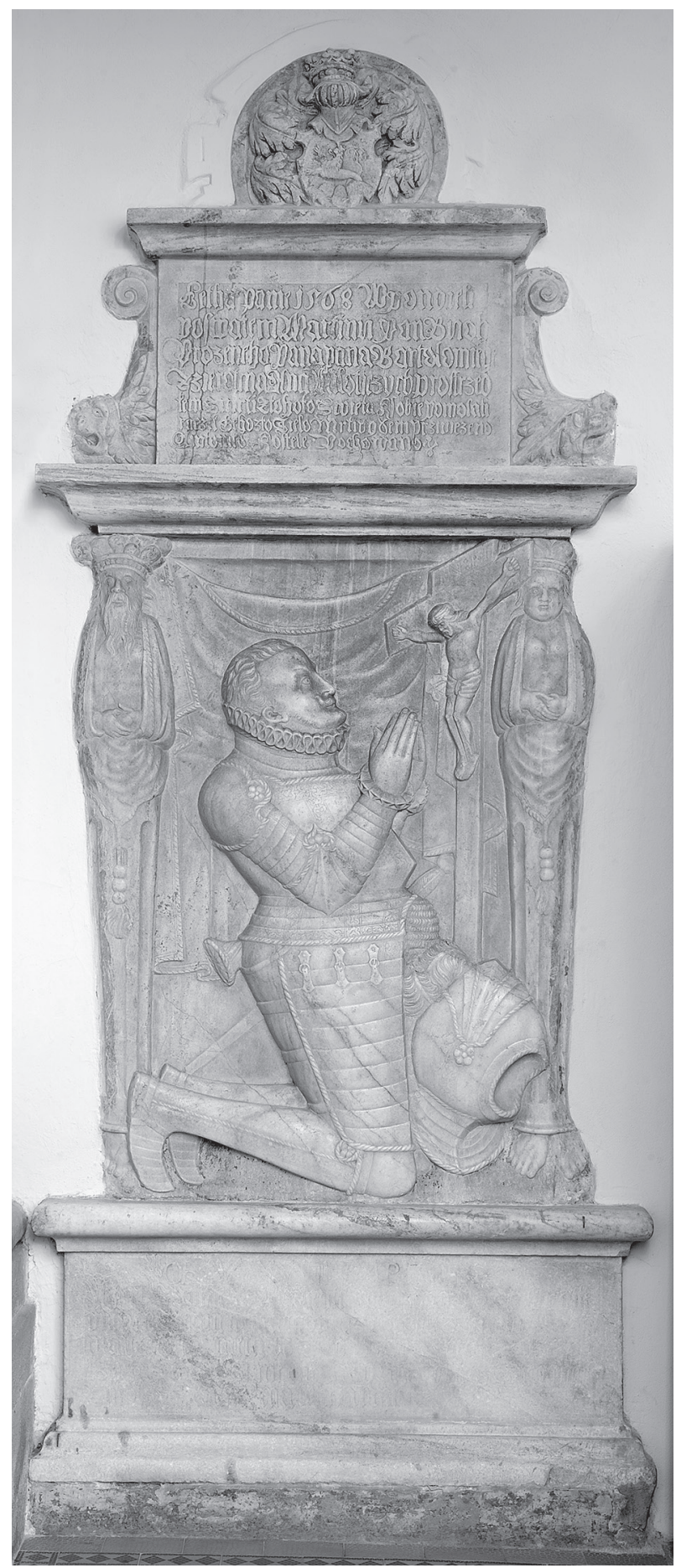

Fig. 16. Master of the Žerotín tombstones: tombstone of Bedřich of Žerotín and of Milotice (d. 15. 11. 1568). Napajedla, Church of St Bartolomew (photo: Petr Zatloukal)

in Moravia, probably genetically bound to prominent creative personalities such as Loy Hering (Fig. 12) and Jan Oslew. Other important circles can be identified in the middle of the sixteenth century, such as the workshop of the Master of the tombstones of the Lords

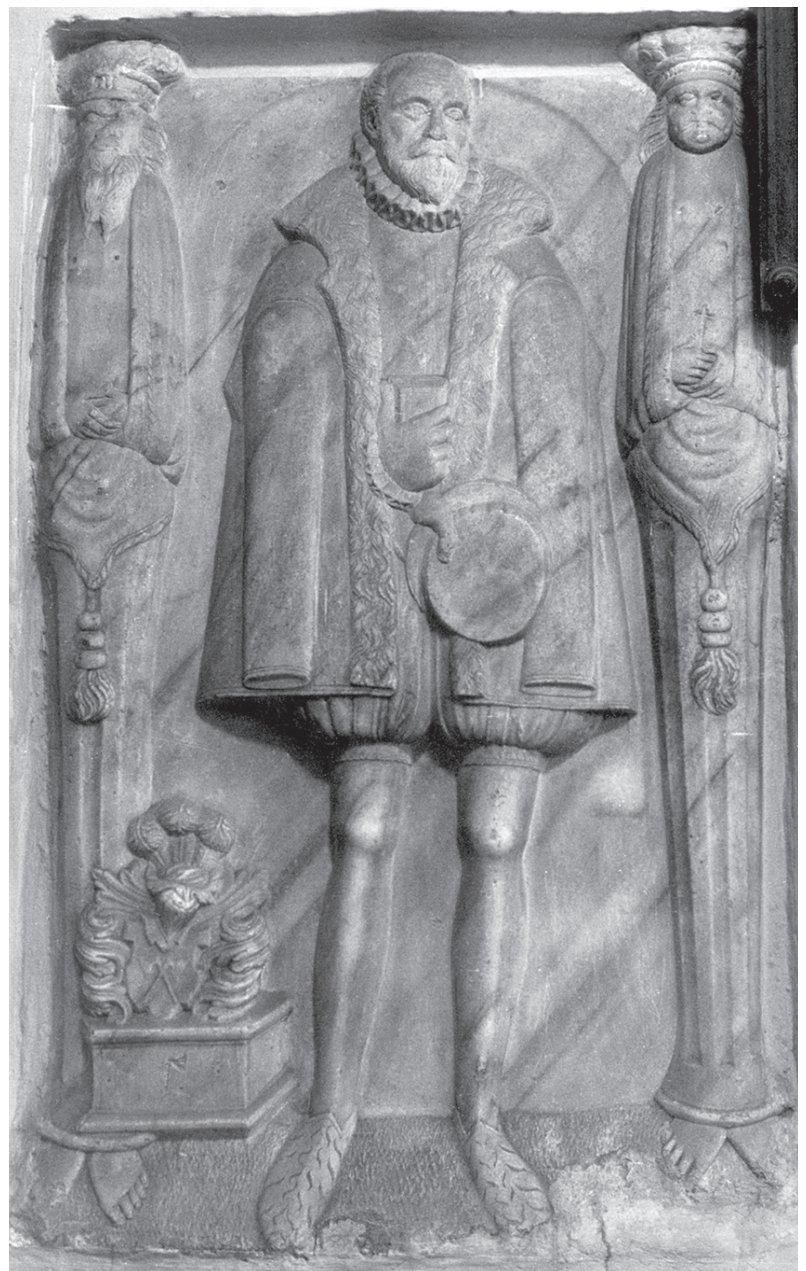

Fig. 17. Master of the Žerotín tombstones: tombstone of Matyáš Dobeš of Olbramice (d. 1579). Černíkovice,

Church of the Exaltation of the Holy Cross (photo: Národní památkový ústav

[National Heritage Protection Institute], regional specialised centre in Pardubice)

of Ludanice, to which twelve noble figural tombstones from the 1550 s to 1570 s - especially in the area of central Moravia - can be attributed (Fig. 13).

Remarkable, expressive, typologically diverse and thoroughly signed works by sculptor Johannes Milicz (Jan Milič also written as Milici, Millyz, Mylliz, Millicz) were created in a relatively short period in the 1560s in Letovice, Jaroměřice and Mohelnice. This creator, known as a scultor in the signature, probably came from a metallurgist family in Most - as revealed by some written sources - and most likely came to Moravia in connection with the creation of several sepulchres for the family of Wolf Dietrich of Hardek (d. 1564) in Letovice (Fig. 14).

In addition to several works by the Master of the Moravičany tombstones, whose work from the turn of the 1560s and 1570s excelled in the generous relief 


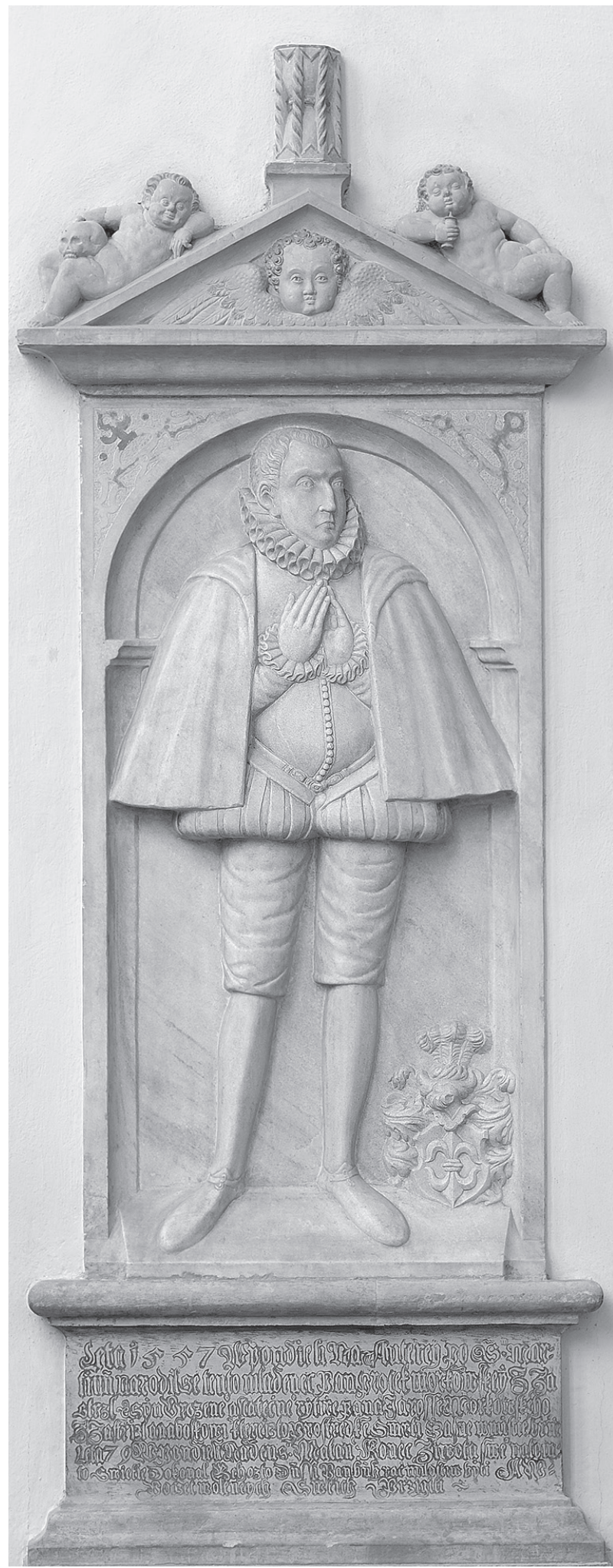

Fig. 18. Master of the Žerotín tombstones: tombstone of Proček Morkovský of Zástřizl (d. 1579). Boskovice, Church of St James the Greater (photo: Petr Zatloukal)

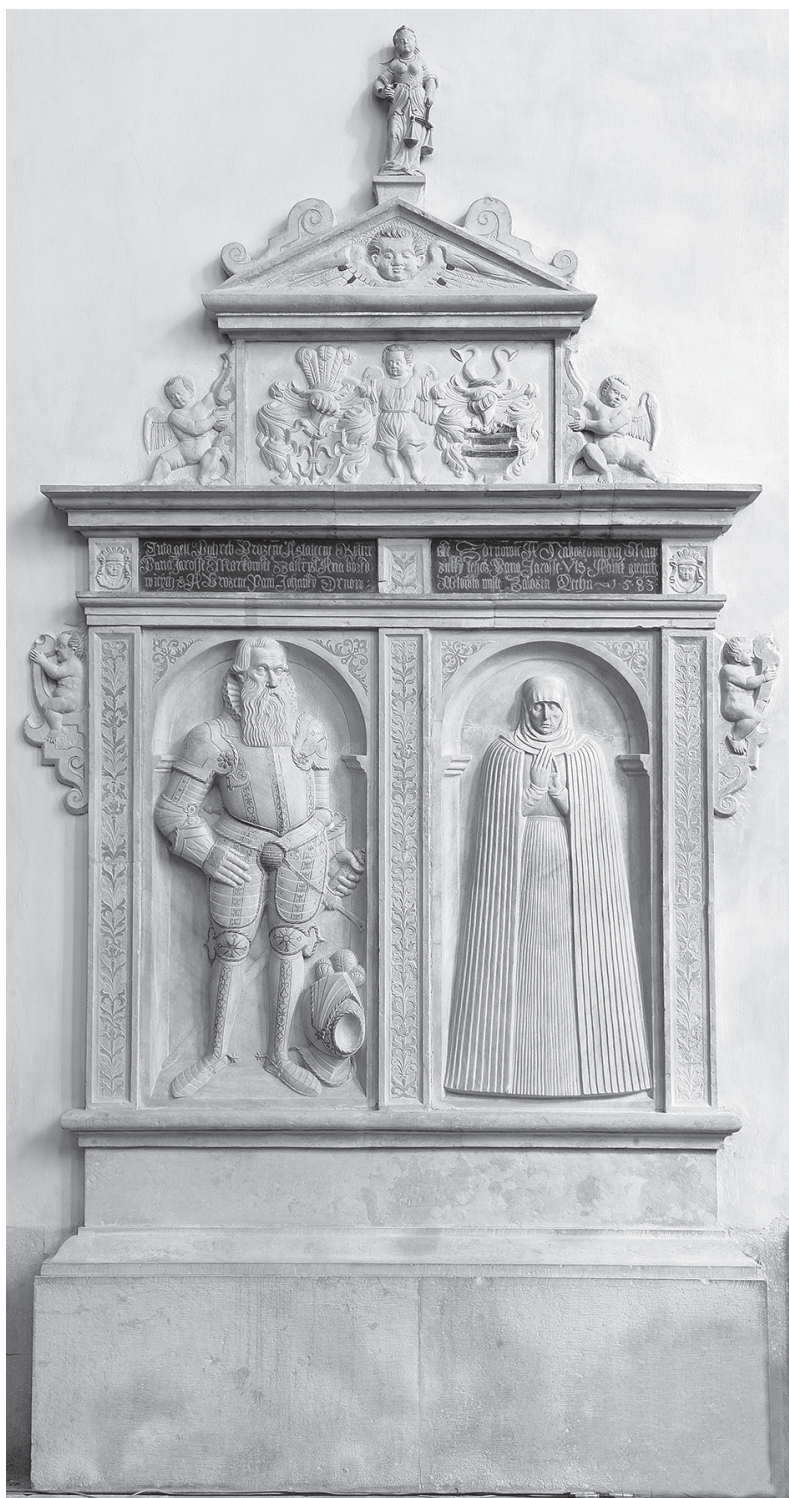

Fig. 19. Master of the Žerotín Tombstones: tombstone of Jaroš Morkovský of Zástřizl (d. 1583) and Johanka Drnovská of Drnovice (d. probably before the year 1589). Boskovice, Church of St James the Greater (photo: Petr Zatloukal)

of the figures (Fig. 15), we can observe quite extensive activity of the so-called Master of the Žerotín tombstones in the 70s and 80s of the sixteenth century. He worked with his workshop for a wider circle of the members of the Žerotín family, not only in Moravia but also in East Bohemia (Figs. 16-17). In Boskovice, he created two remarkable sepulchres for Proček Morkovský of Zástřizl (d. 1579) and for his parents Jaroš Morkovský of Zástřizl (d. 1583) and Johanka Drnovská of Drnovice (d. probably before the year 1589) (Figs. 18-19). The personality of the author inspired by Dutch Mannerism has not been identified, but some indications 
suggest that it might be Jindřich Pražák or Beránek, later documented in Prague. ${ }^{29}$

The Master of the tombstone of Jan Proček of Zástrizl, named after one of his most typical works in Cholina (Figs. 20-21), followed the creative legacy of Johannes Milicz and was more directly linked to the Master of the Moravičany Tombstones. In the Moravian material we managed to trace only a few of his works, which are closely connected on the base of their quality and character of their craftsmanship. These works, however, are followed by simpler sepulchres of the work-

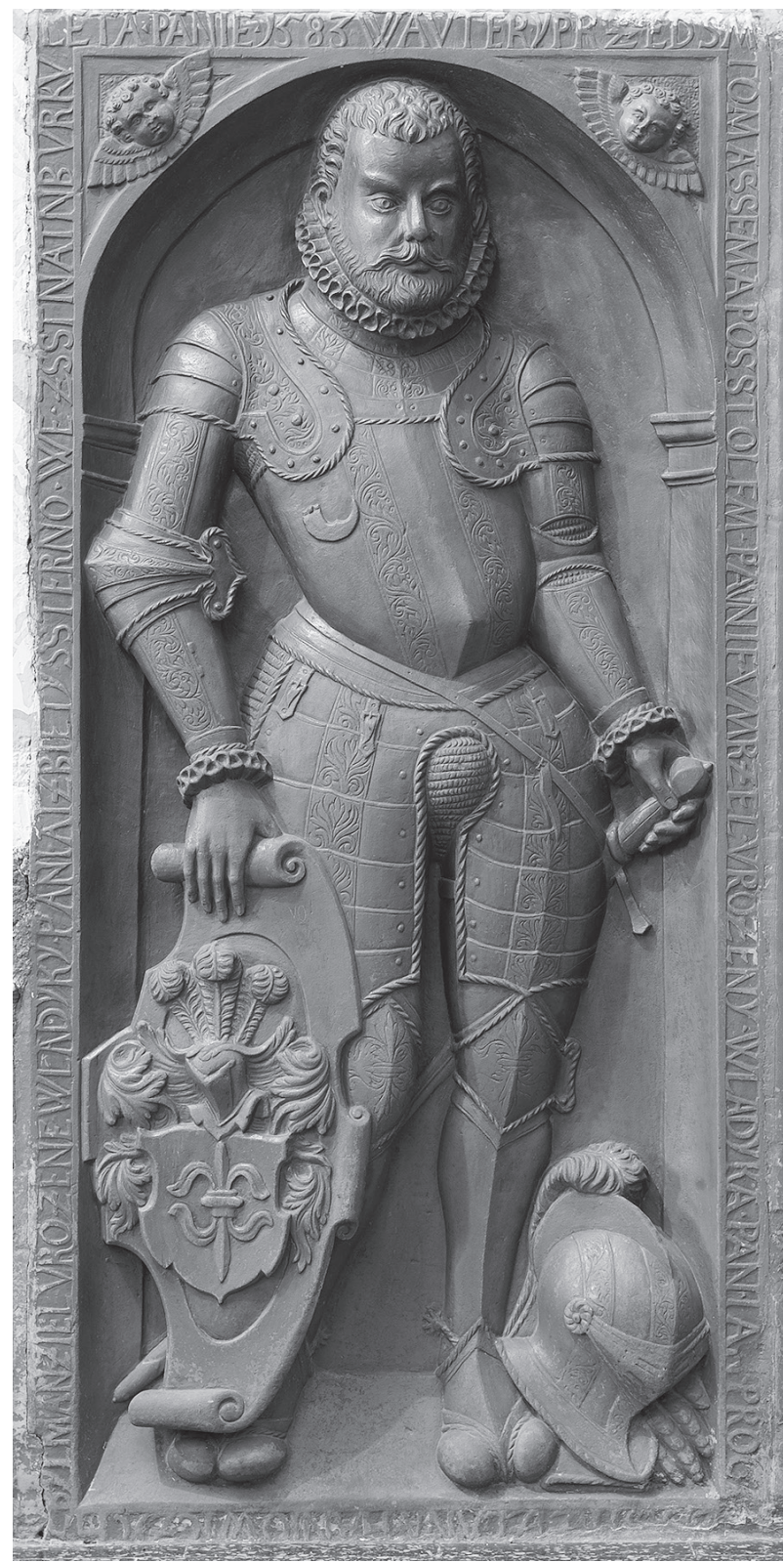

Fig. 20. Master of the tombstone of Jan Proček of Zástřizl: tombstone of Jan Proček of Zástřizl (d. 1583).

Cholina, Church of the Assumption of the Virgin Mary (photo: Petr Zatloukal) shop or his successor. It is likely that this sculptor came to Moravia as a co-author of the ambitious Manneristic monument, the tombstone of Jan Fridrich the Earl of Hardek and Stattenberg (d. 1580) in Letovice, and his wife Elisabet of Monesis in Kunštát (d. 1592?) (Fig. 22). The possibility of the fact, that this work was inspired by the art of international Mannerism is more than likely, although the sources are not documented, but it is also supported by the personal and social relations of the depicted persons to the Prague Habsburg court.

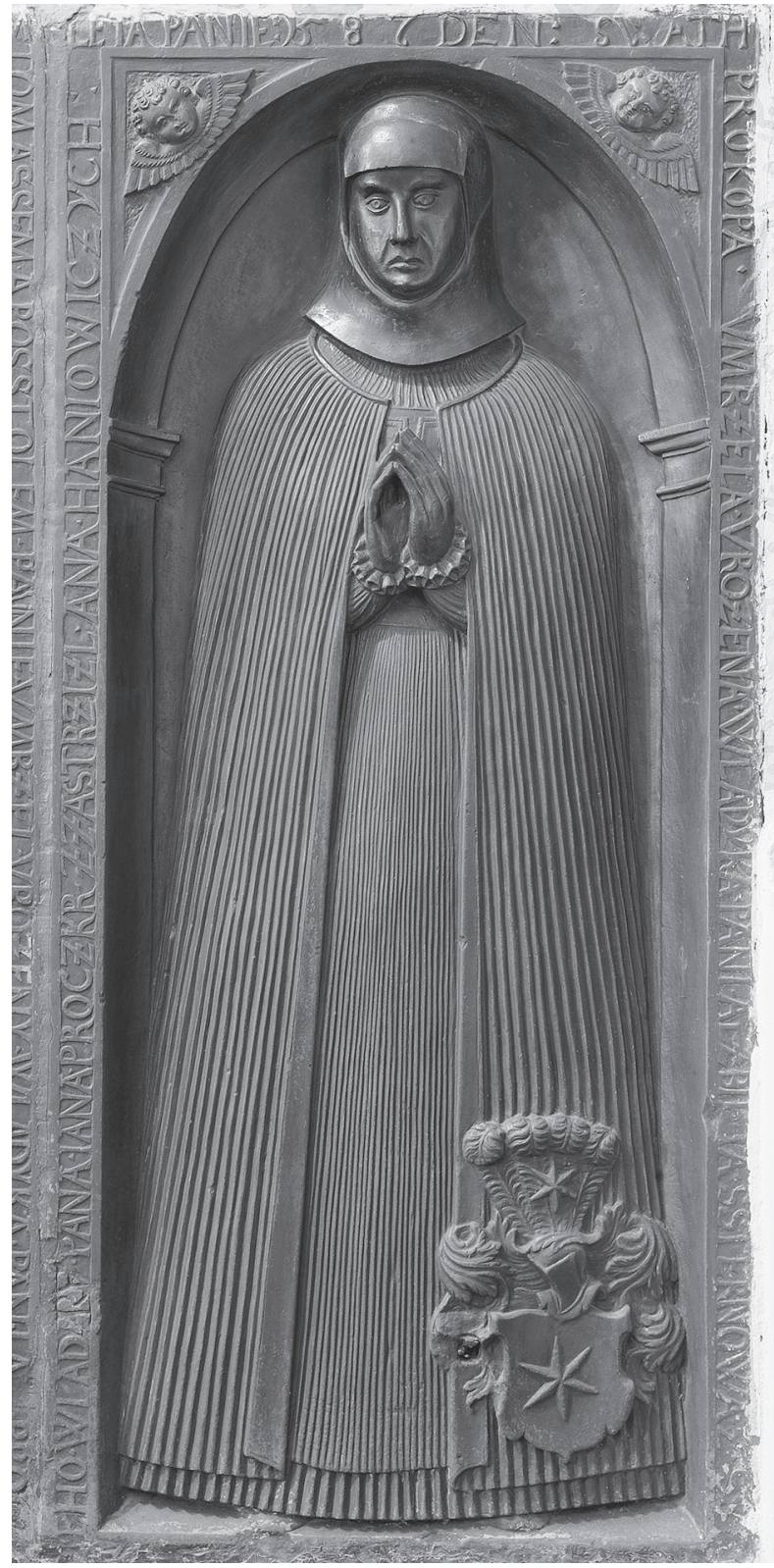

Fig. 21. Master of the tombstone of Jan Proček of Zástřizl: tombstone of Alžběta Šternová of Štatenburk (d. 1587). Cholina, Church of the Assumption of the Virgin Mary (photo: Petr Zatloukal) 
The apparent Manneristic character is also evident in the work of the Master of males' tombstones, active in Moravia from the late 1580s to the early 1590s. His vivid and expressively stylized male figures contrast somewhat with the convulsive Manneristic stylization of female characters, revealing the participation of a co-worker in the workshop who did not reach the same high level of craftsmanship (Figs. 23-24). A significant group of eleven works is connected with the workshop of the Master of the tombstone of Václav Berka of Dubá and Lipý. The activity of this workshop is traceable from the commission of the Moravian noblewoman Alena of Lomnice. She had a figural tombstone and a heraldic gravestone made for her husband buried in Prague, who inspired the name of the workshop's leading personality (Fig. 25). Sepulchral monuments of this circle characterized by outstanding quality of craftsmanship of characters in graceful and almost strikingly curved postures were created in the period from the beginning of the 1570s to the end of the sixteenth century by a sculptor of apparently Italian origins who was acquainted with Central European art, and by his workshop in which he undoubtedly employed specialised artists. Given the location of the work and the nature of the clientele, it can be concluded that the work of the master and his workshop was probably connected with the Brno region (Figs. 26-27). A distinctive style and durability of expression characterize the three tombstones of the Master of the tombstones of the family of Petr Vlk of Konecchlumí in Slavkov in the Opava region, apparently commissioned by Peter's brother Jiři at the time when he took over the property and rebuilt the fortress into a Renaissance chateau in 1572-1586 (Fig. 28). The character of the works suggests a connection with the Saxon and Silesian works of the Walther family in Dresden, in particular with the Frýdlant tombstone of the Redern family, carried out by Hans II Walther in $1565-1566$.

The quality of these works influenced the production of the workshop of the Master of the tombstones in Sedlnice, to which fourteen sepulchres in the territory of North Moravia and in the adjacent area of Silesia, resp. in the Principality of Cieszyn ${ }^{30}$ can be attributed. The work of the workshop - which was active in the last third of the sixteenth century - represented a qualitative average. In terms of style and expression, it forms a relatively consistent part of the local sepulchral production (Figs. 29-30). The work of another workshop with formal style and craft operating in north Moravia and Czech Silesia in the 1590s is illustrated

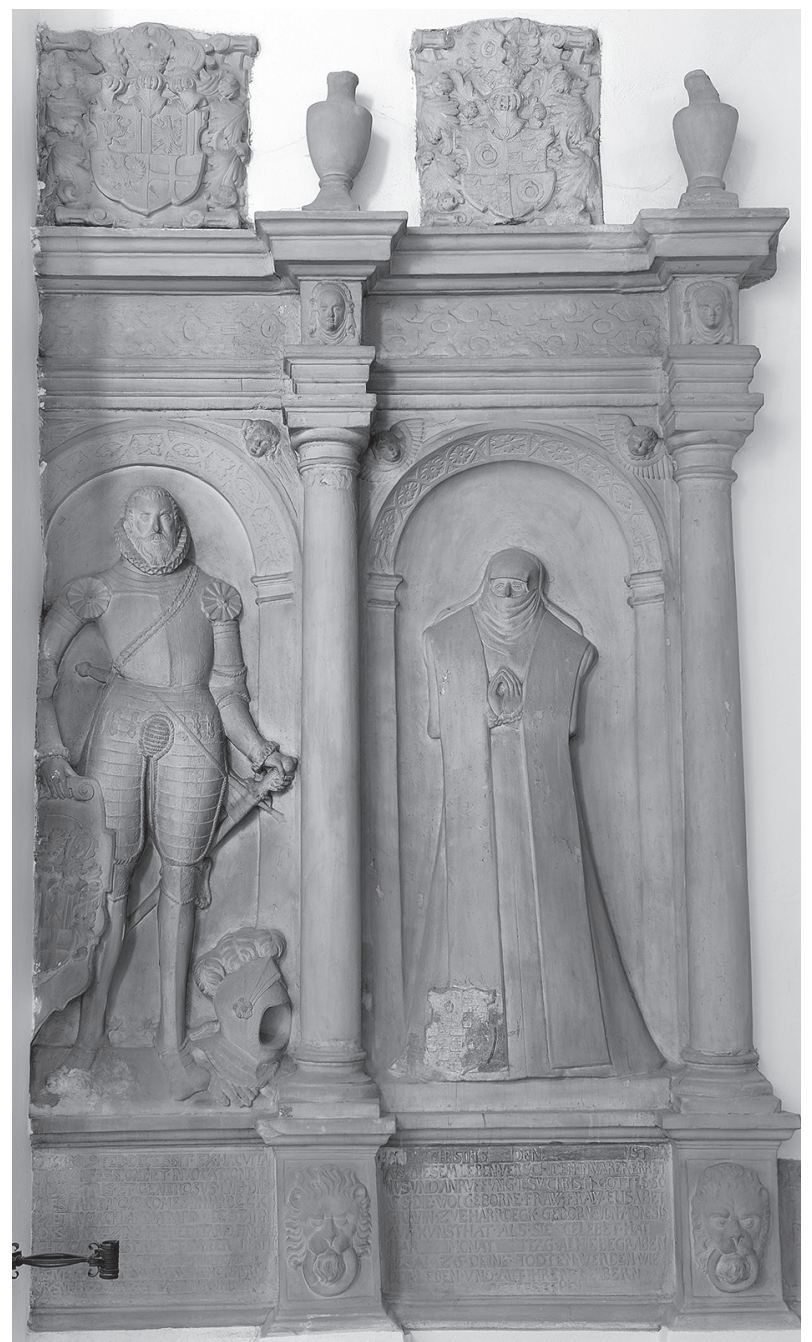

Fig. 22. Master of the tombstone of Jan Proček of Zástřizl: tombstone of Jan Fridrich the Earl of Hardek and of Stattenberk (d. 1580) and his wife Elisabet of Monesis in Kunštát (d. 1592?). Letovice, Church of St Procopius (photo: Petr Zatloukal)

by the twelve works of the Master of the tombstones of the Sedlnicky family of Choltice in Bartošovice, which are characterised by their generous summary but stylised rendition of static male and female characters, and the consistent architectural framing of figural slabs (Figs. 31-33). In the first decade of the seventeenth century, it is possible to trace the work of the Master of the tombstone of Jan Žalkovský of Žalkovice in Dobromilice on several isolated sepulchres (Fig. 34). At the Žerotín estate in Moravská Třebová and the Valdštejn estate in the Trutnov region in north-eastern Bohemia, eight tombstones with strictly frontally rendered figures of the elongated proportions by the Master of the tombstones of the Litvic family of Staré Roudno have been preserved from the later period of the end of the first quarter of the seventeenth century (Fig. 35). 


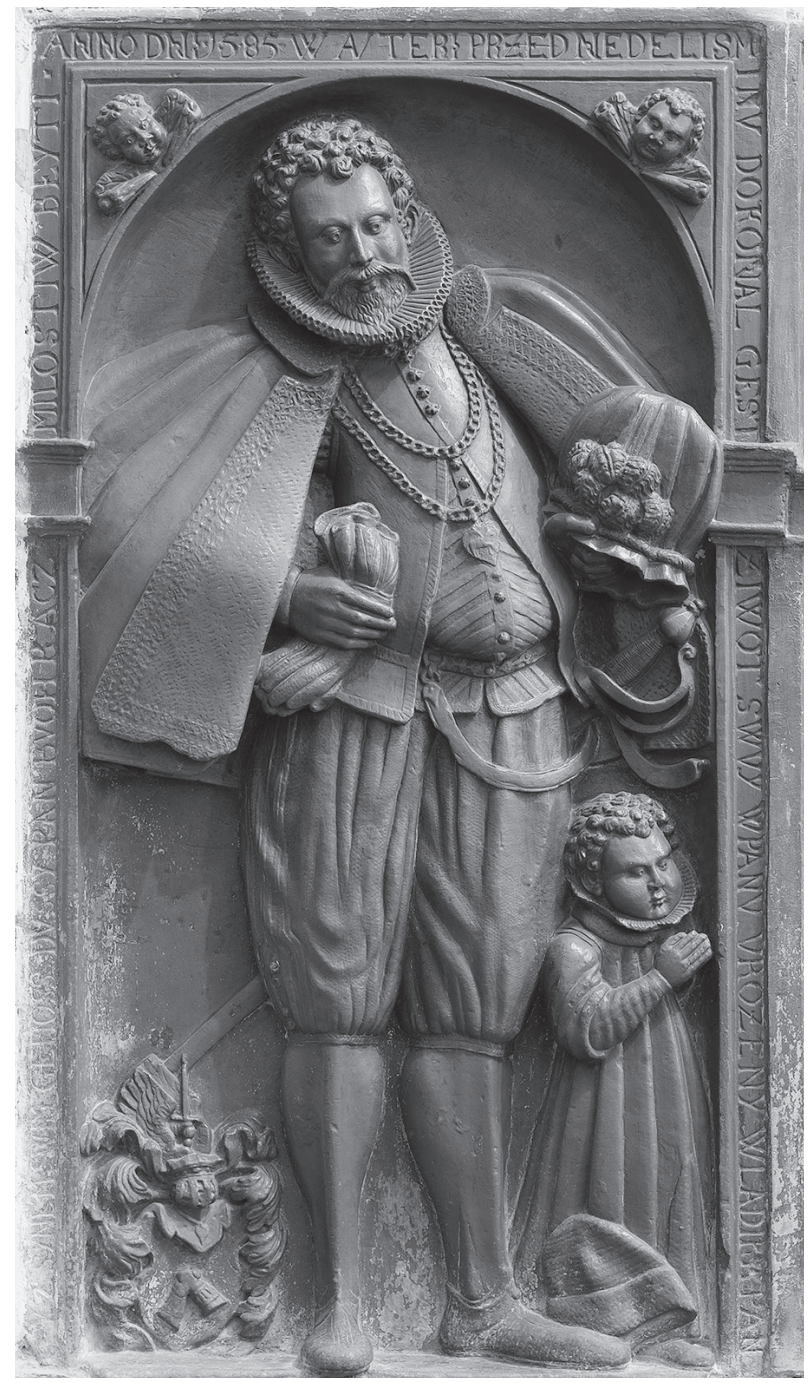

Fig. 23. Master of the males' tombstones: tombstone of Jan Zoubek of Zdětín and his son (d. 1585).

Cholina, Church of the Assumption of the Virgin Mary (photo: Petr Zatloukal)

However, the scope of the research until now aiming at the synthetic elaboration of Moravian and Silesian sepulchral monuments did not include the production of all active Moravian and Silesian masters and workshops, but rather focused on the most striking examples, which had proven to have informative and relational value due to the observed characteristics.

The fact that the area in question is distinguished by a significant production of knights' tomb monuments has a deeper historical and social context. The tomb monument was closely related to the spiritual and social world of the Renaissance man. Therefore it was necessary to concentrate not only on the provenance of typological, compositional and stylistic forms, but also on the functional and social aspects

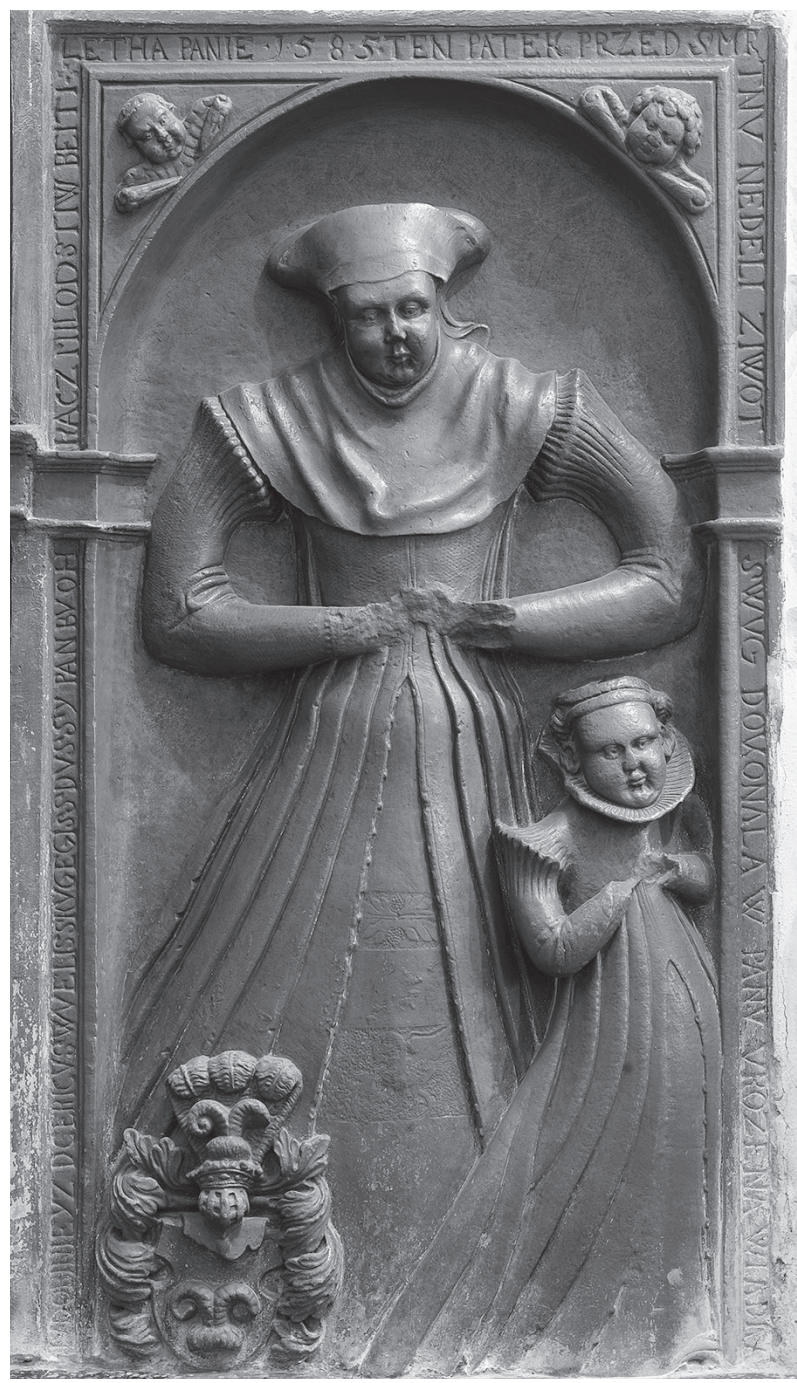

Fig. 24. Master of the males' tombstones and the workshop: tombstone of Alena Okrouhlická of Kněnice and her daughter Eliška (d. 1585). Cholina, Church of the Assumption of the Virgin Mary (photo: Petr Zatloukal)

of this production in which the ability of our region accepting new forms and operating with spiritual humanistic contents has become apparent.

The situation of Moravia and Czech Silesia at the end of the fifteenth century and during the sixteenth was characterised by an absence of a secular princely power centre. Property ownership and power concentrated in the hands of the bishop and local noble families, such as the Pernštejn, Cimburk, Boskovice, Ludanice, Žerotín families, etc. Their representatives held leading provincial offices and were also in contact with the court culture of ruling centres in Budín, later in Prague, in Vienna and Krakow. The Moravian aristocracy, which in the sixteenth century experienced a period of economic and political rise, was so rich that it was actively involved in creating a Renaissance 


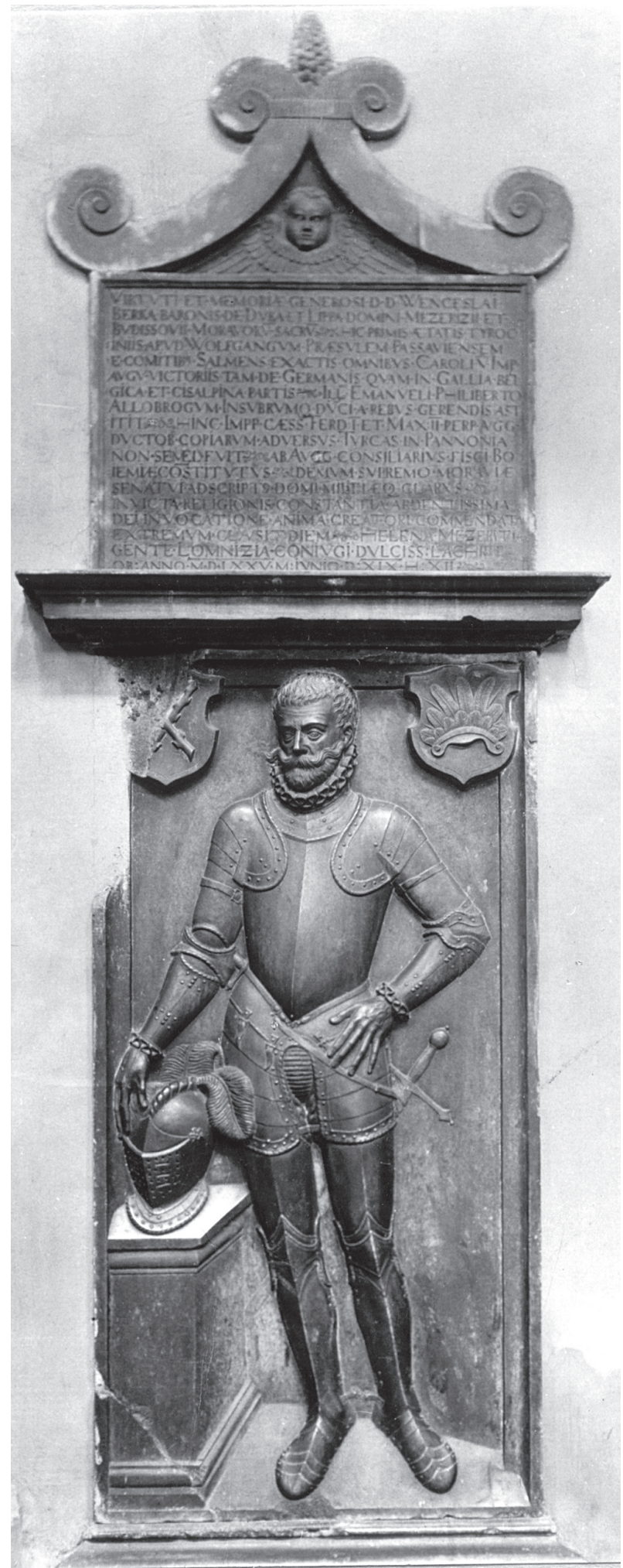

Fig. 25. Master of the tombstone of Václav Berka of Dubá and Lipý: tombstone of Václav Berka of Dubá and Lipý (d. 1575). Prague, Church of Our Lady before Týn (photo: Hana Myslivečková)

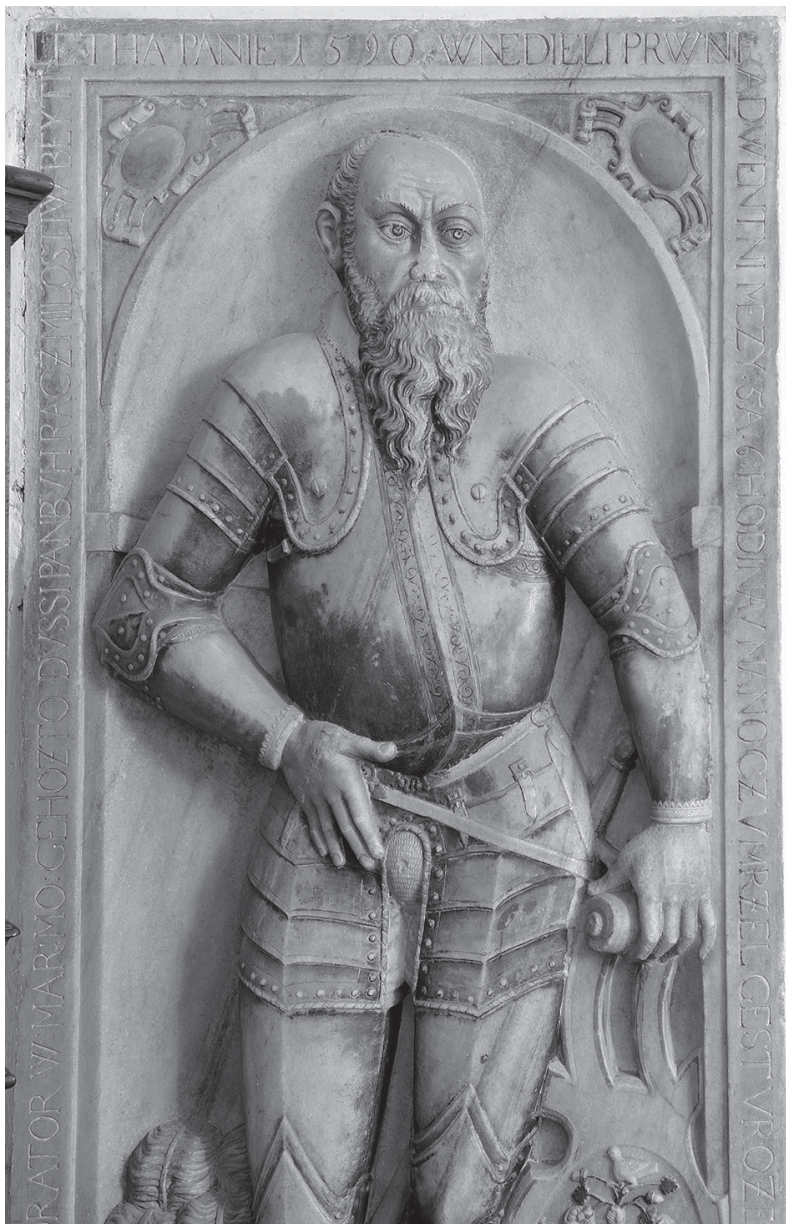

Fig. 26. Master of the tombstone of Václav Berka of Dubá and Lipý, tombstone of Matyáš Žalkovský of Žalkovice, prosecutor of Margraviate of Moravia (d. 1590). Dobromilice, All Saints Church (photo: Petr Zatloukal)

or Manneristic environment, affecting all areas of life, directly in their estates. ${ }^{31}$

The most important tasks of the Renaissance work of the time included not only the construction of the chateau which is the 'earthly residence', but also the 'eternal residence', the chapel and the tombstone. These circumstances prompted the emergence of many representative Renaissance sepulchral monuments, which in addition to religious and private memorial functions, also served as gender policies. ${ }^{32}$ In the local noble families the whole-figure sepulchres gradually became popular, which were in its attributes reminiscent of knightly virtues, updated especially in times of Turkish threat. In addition to eschatological significance, the tombstones became representative artefacts which - in addition to depicting the deceased - accentuated the attributes of traditional military aristocratic symbolism and the importance of ancestral representation, including an armour, sword, shield 


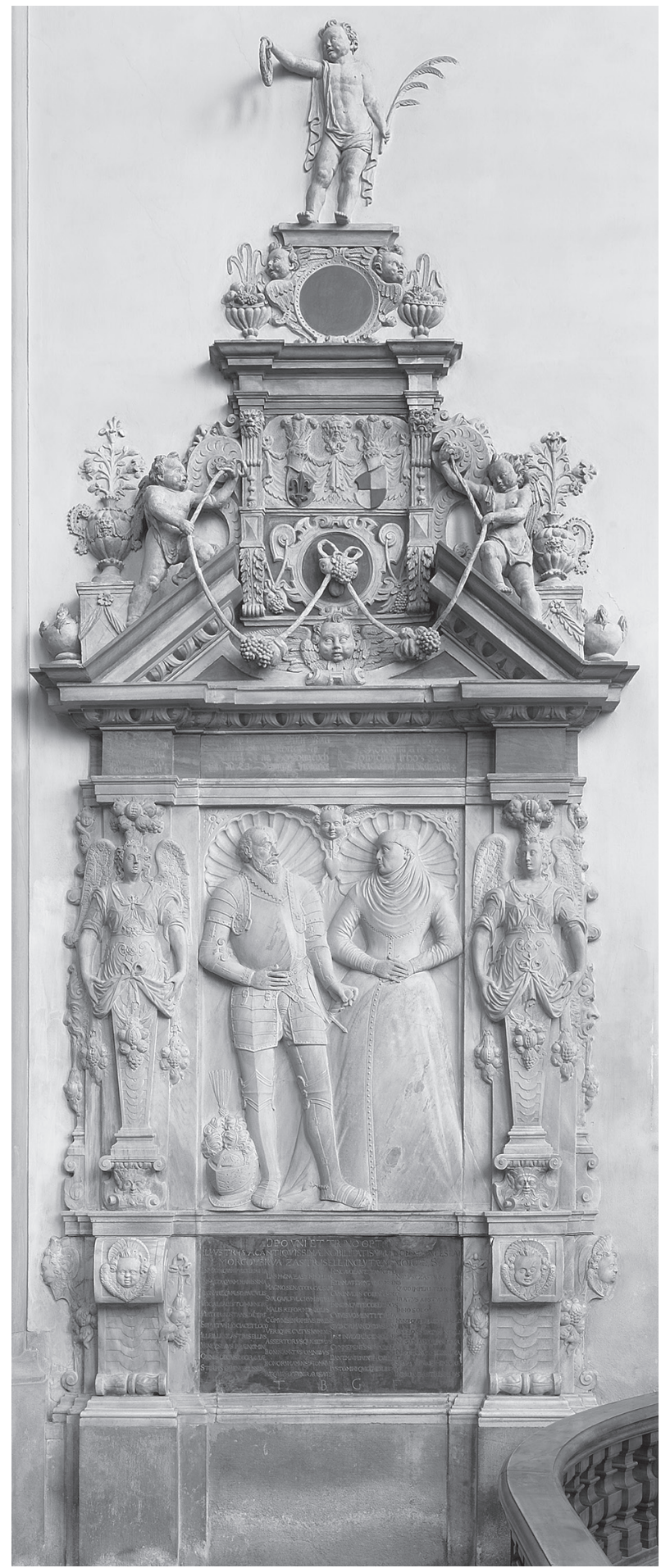

Fig. 27. Master of the tombstone of Václav Berka of Dubá and Lipý: tombstone of Václav senior Morkovský of Zástřizl (d. 1600), a courtier of the Emperor Rudolf II and Kunka of Korotín (d. 1607). Boskovice, Church of St James the Greater (photo: Petr Zatloukal)

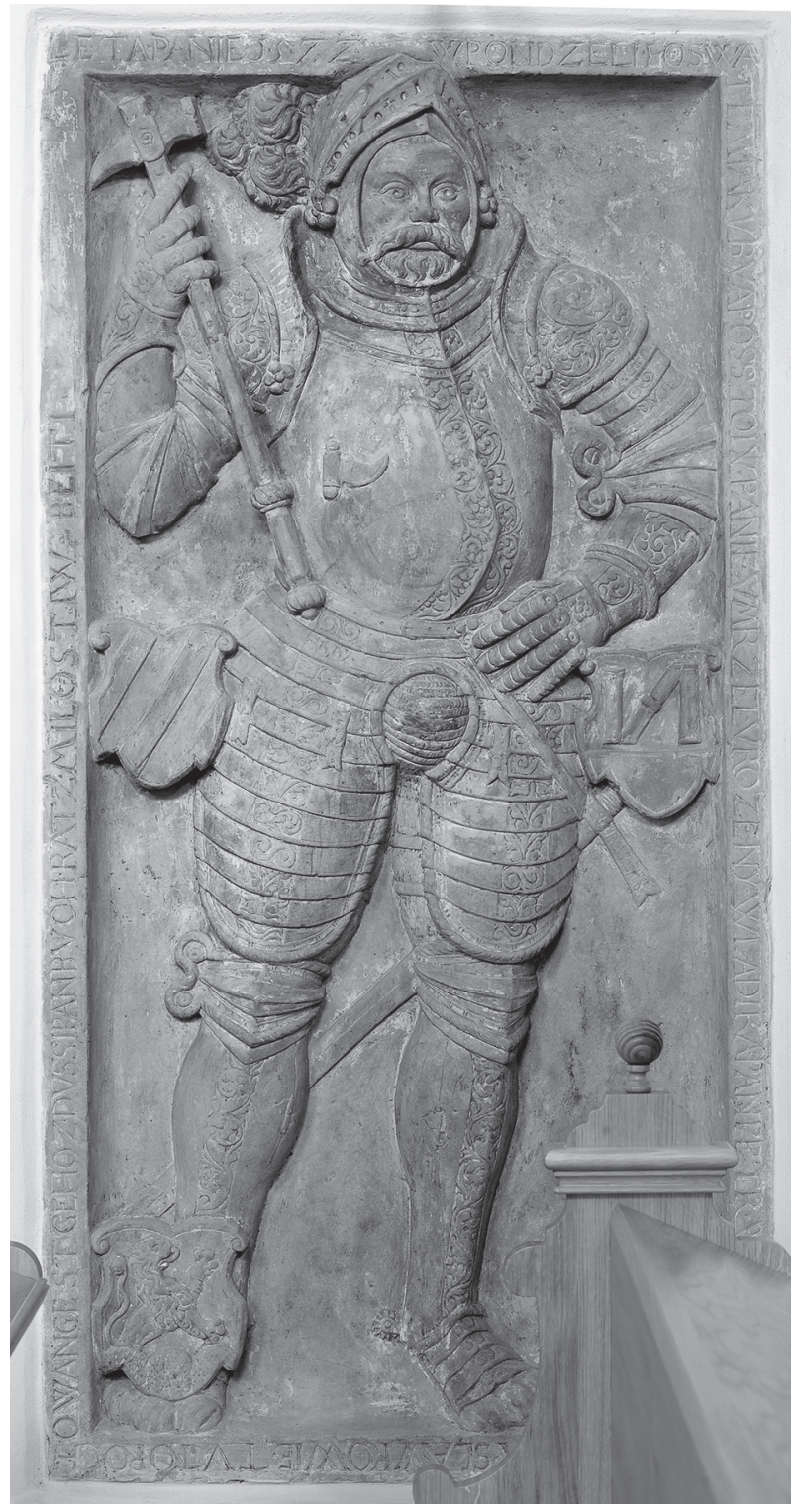

Fig. 28. Master of the tombstones of the family of Petr Vlk of Konecchlumí: tombstone of Petr Vlk of Konecchlumí (d. 1572). Slavkov, Church of St Anna (photo: Petr Zatloukal)

with ancestral coat of arms, inscription and sometimes a banner.

In the sepulchral collection of Moravia and Czech Silesia in the first half of the sixteenth century the preserved knights' tombstones with a banner, which often follow the examples of the Danube region, are not very numerous, but still forming a remarkable typological group, although later they appear rarely. In this type of depiction, the aristocracy referred to the medieval warrior tradition of the so-called 'wielding masters', because in the current politically and administratively complicated situation aristocracy sought to strengthen its own professional position. 
These are exemplified mostly by late Gothic tombstones such as that of Jiří of Žerotín (d. 1507) in Fulnek (Fig. 2) or the tombstone of Arkleb of Víckov (d. 1538) in Prusinovice (Fig. 3). This latter monument of the son of Přemek of Víckov, the valet of a lesser land right in Olomouc and the vice-chamberlain of Margraviate of Moravia is apparently a work of

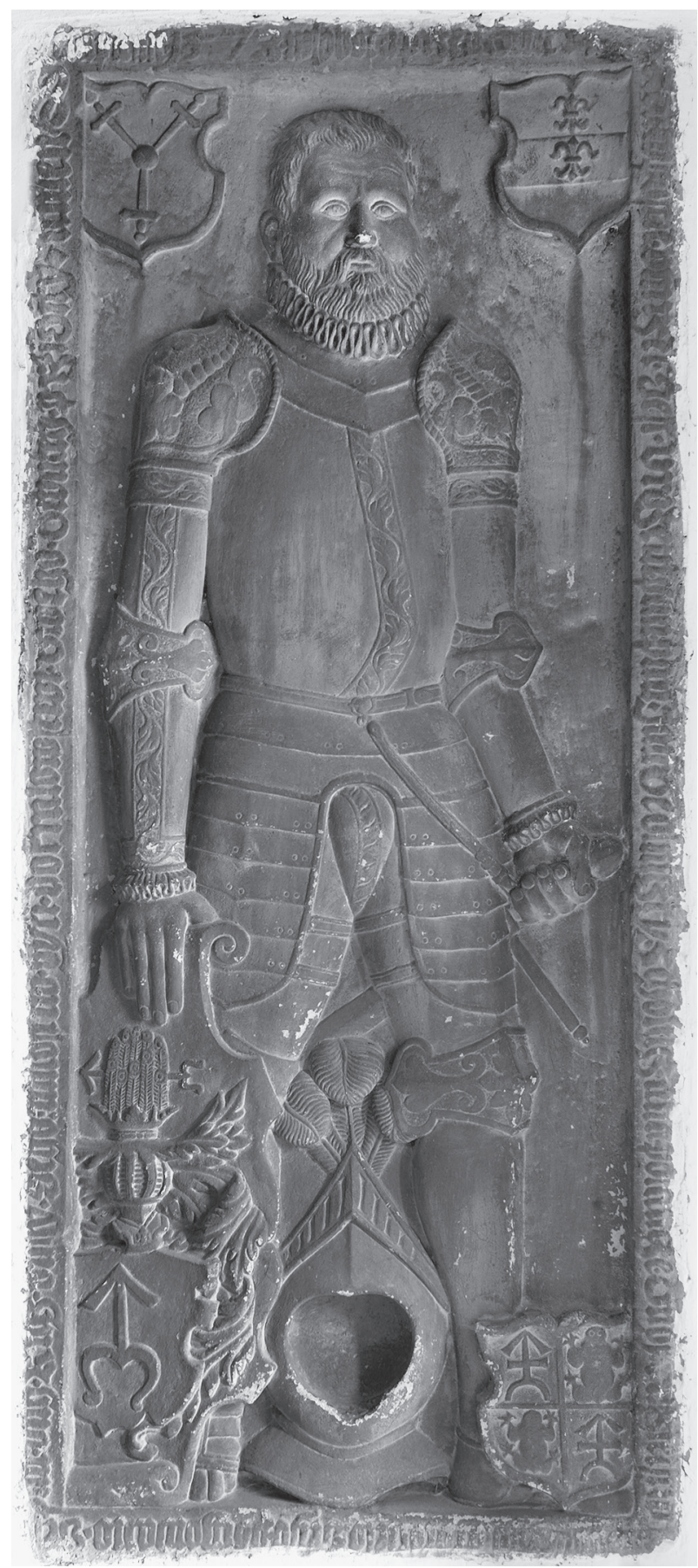

Fig. 29. Master of the tombstones in Sedlnice: tombstone of Jan Sedlnický of Choltice (d. 1573), a provincial judge of the Principality of Opava. Sedlnice, Church of St Michael the Archangel (photo: Petr Zatloukal) provenance associated with a fragment of the tombstone of Kryštof Kropáč of Nevědomí (d. 1535) from Skalice (Szakolca in the former Kingdom of Hungary, today Slovakia) (Fig. 36). Today it is in the exposition of the medieval lapidary of the Hungarian National Museum in Budapest. ${ }^{33}$

Following the medieval tradition, an important tool for gender identification and representation was the use of a coat of arms or two- or four-heraldic lineage, usually placed in the corners of the plate (fourcornered lineage), even if the figure was surrounded

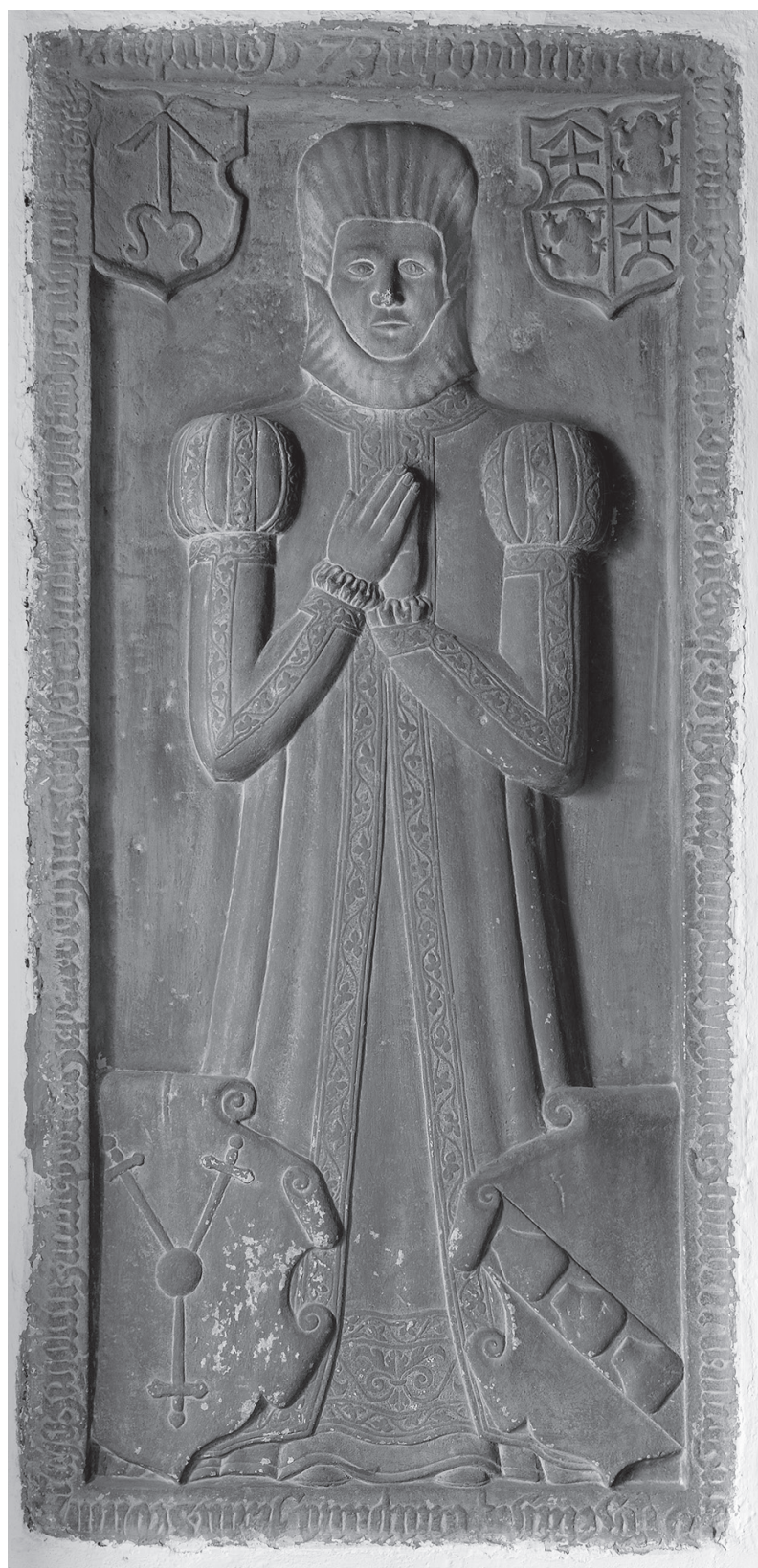

Fig. 30. Master of the tombstones in Sedlnice: tombstone of Johanka Žabková z Limberka (d. 1573). Sedlnice, kostel sv. Michala archanděla (photo: Petr Zatloukal) 


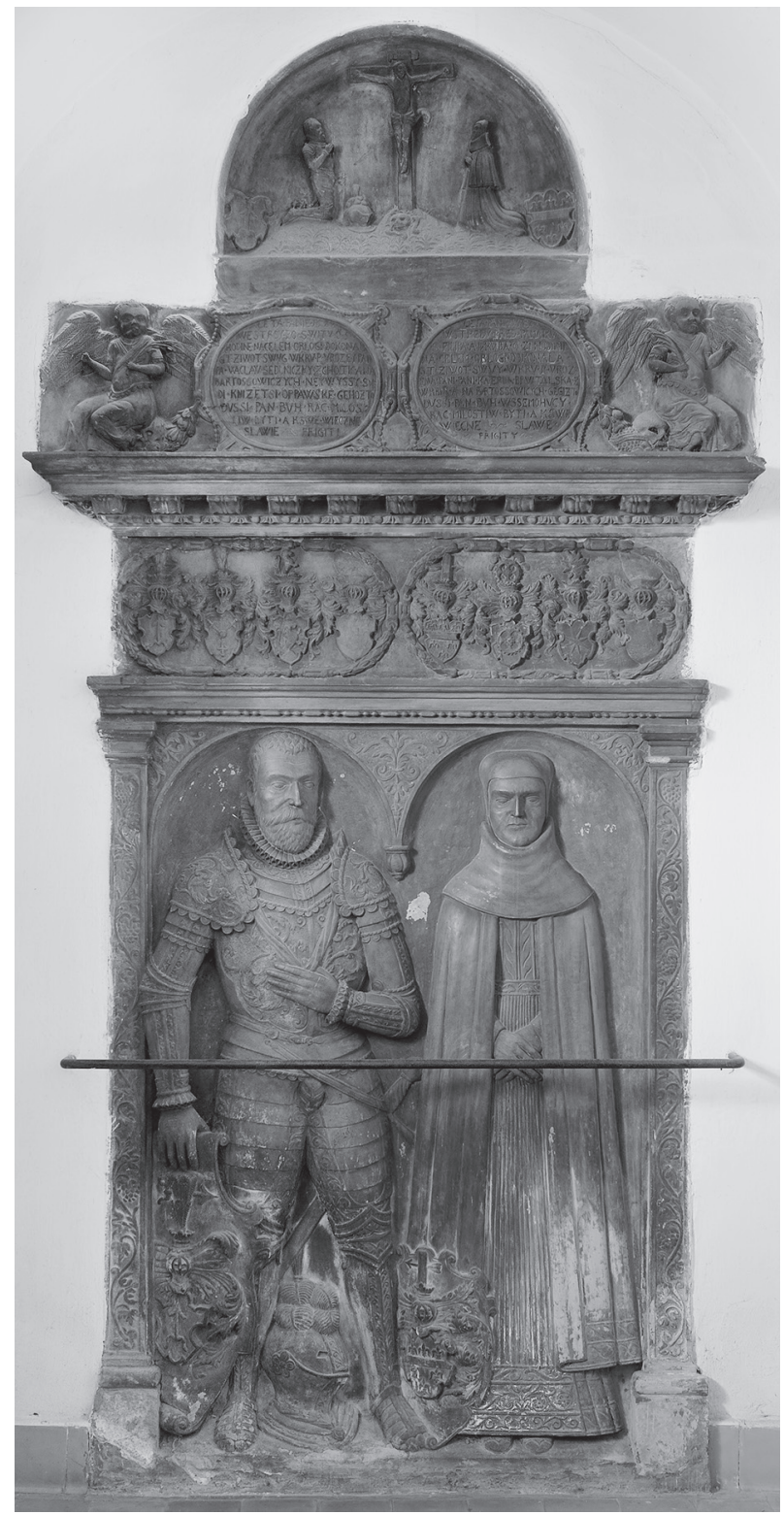

Fig. 31. Master of the tombstones of the Sedlnický family of Choltice in Bartošovice: tombstone of Václav Sedlnický of Choltice (d. 1588), a supreme judge of the Principality of Opava, and Kateřina Bruntálská of Vrbno (d. 1586). Bartošovice, St Peter and Paul Church (photo: Petr Zatloukal)

by a niche. ${ }^{34}$ In male figures of Moravian noblemen, the coat of arms typically dominated the tombstones often placed on a variously shaped large shield or cartouche alongside the deceased. The coats of arms and heraldic lineage could also be placed on additional parts of the tombstone, in the frieze, in the extension or base of the aedicula of the architecturally composed framing or on the walls of the tomb. This suggests that in the production of aristocratic tombstones, in which the representation of the per- son and the family - referring to the values of medieval knighthood - played an important symbolic role, traditional male sepulchral models had much longer inertia than female ones. It appears as though the style all'antica penetrated into the figural tomb production at a different pace and manner than into the production of heraldic sepulchres or architectural sculpture, in which its effects could manifest freely, according to the wishes of the customers. The power and social representation was also related to the construction of family burial grounds or burial churches which were supposed to confirm the continuity and real power of the family. These included the family of Pernštejn in Doubravník and Pardubice, the Prusinovský of Víckov in Prusinovice, the Žerotíns in Napajedla, the Žalkovský in Dobromilice, the Brtnický of Valdštejn in Brtnice, the Zástřizl in Boskovice, the Sedlnický in Bartošovice, the Bzenec of Markvartovice in Klimkovice, the Rotmberský of Ketra in Štáblovice, the Bruntálský of Vrbno in Bruntál and Hlučín, etc. To defend their social and political position, the aristocracy used various forms of contemporary representation, which grew out of humanistic ideas while adopting and transforming iconographic elements and formulas of ancient triumphal symbolism in various ways. ${ }^{35}$ It was characteristic of Moravia in the second half of the sixteenth century that most of the courts were created by the Protestant aristocracy, therefore the question was raised whether the Moravian aristocratic culture at the turn of the sixteenth and seventeenth centuries had a 'confessional type', and if and how much the culture of Moravian Catholic and Evangelical aristocrats differ from one another. ${ }^{36}$ However, much suggests that despite religious excitement, Moravia was one of the most liberal countries in Europe during the sixteenth century until the White Mountain denouement in 1620. ${ }^{37}$ Therefore, the distinction between Catholics and non-Catholics; especially Lutherans, Unity of Brethren and Calvinists is often difficult and ambiguous, as the conditions were rather intricate and unstable. It is noteworthy, however, that the most representative examples of sepulchral monuments - almost portrait depictions and rich decorative sets are found in the environment of the Protestant aristocracy at the end of the sixteenth century. It is evidenced by marble sepulchres of married couples, namely of Jan Fridrich the Earl of Hardek (d. 1580) and Elisabet of Monesis in Letovice (Fig. 22) and Václav Morkovský of Zástřizl (d. 1600) and Kunka of Korotín in Boskovice (Fig. 27), which are characterised by extraordinary dimensions and complexity of their design. The 


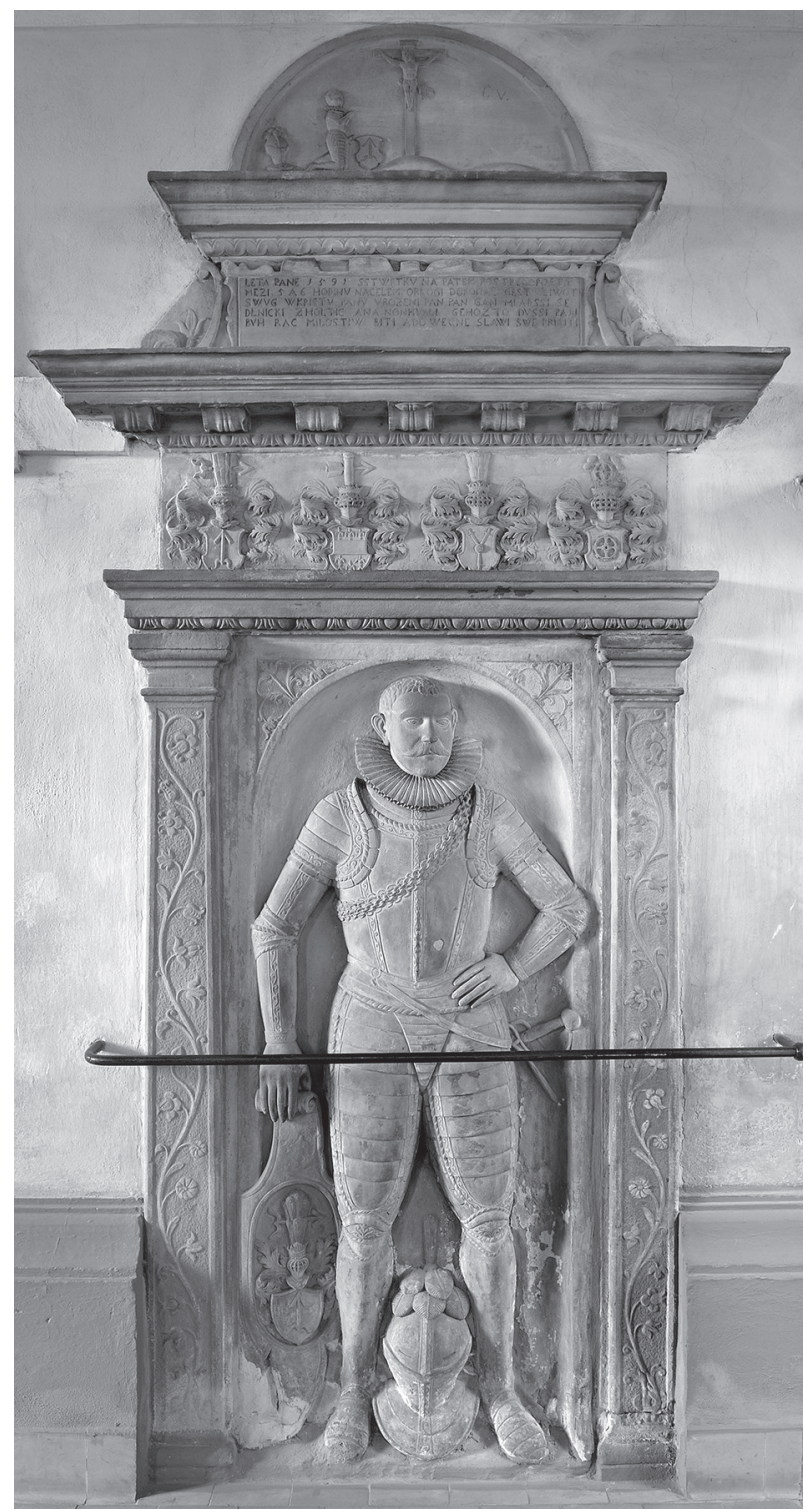

Fig. 32. Master of the tombstones of the Sedlnický family of Choltice in Bartošovice: tombstone of Jan junior Sedlický of Choltice (d. 1591). Bartošovice, St Peter and Paul Church (photo: Petr Zatloukal)

cultural level of the commissioners of these monuments stemmed from the education and humanistic knowledge that the members of aristocratic families acquired at Europe's leading (especially Protestant) universities. ${ }^{38}$ It was no exception that these nobles were engaged in the service of the Habsburg emperors and absorbed impulses from this multinational culturally and artistically saturated environment. An analysis of the activities of the families of the Lutheran Church or the Unity of Brethren religion; based on the pursuit of Christian life, moral genuineness and discipline suggests the predominantly socio-representative purpose of sepulchral commissions that can be a sur-

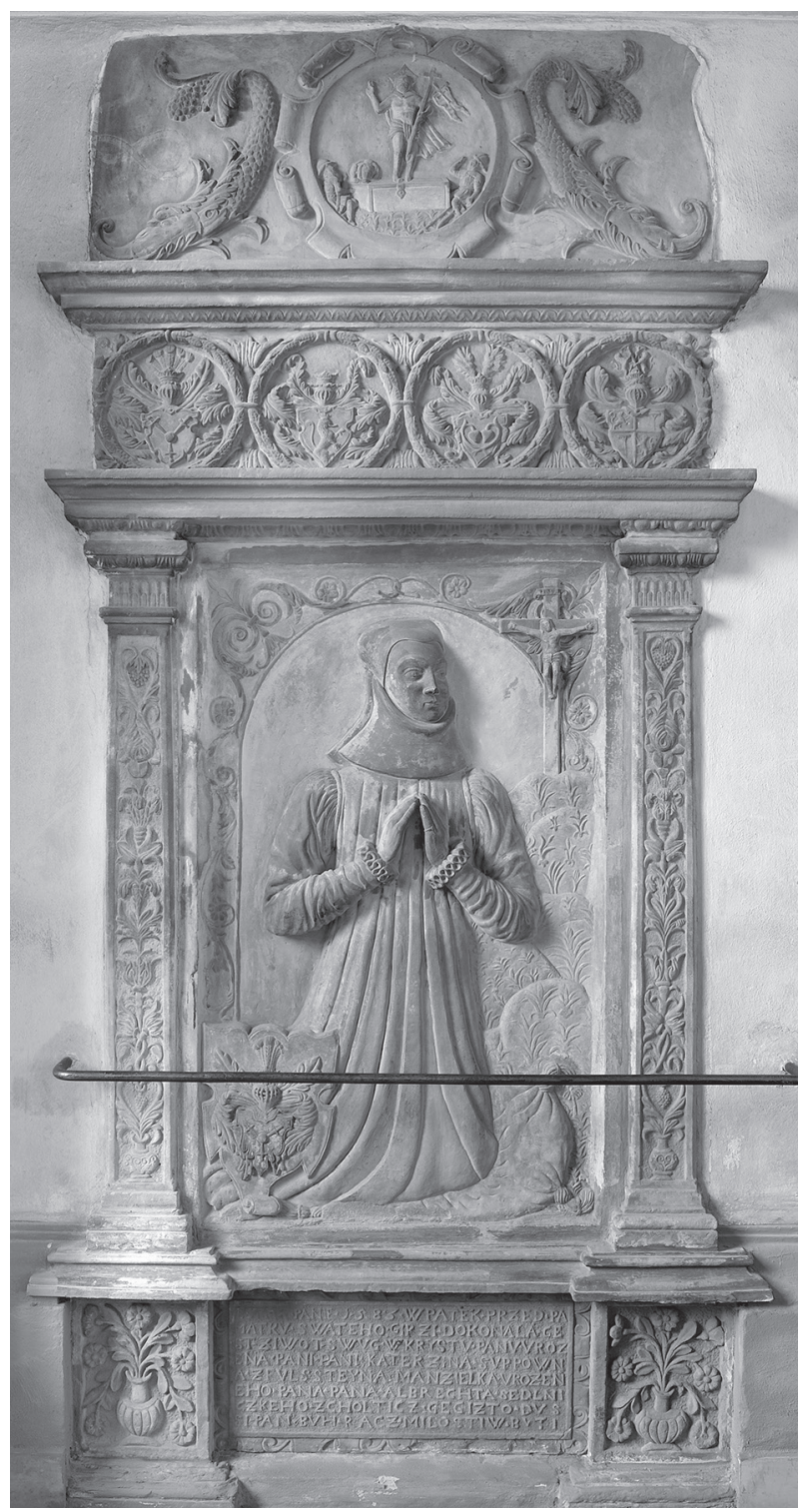

Fig. 33. Master of the tombstones of the Sedlnický family of Choltice in Bartošovice: tombstone of Kateřina Supovna of Fulštejn (d. 1583). Bartošovice, St Peter and Paul Church (photo: Petr Zatloukal)

prising element in an environment in which the establishment of spectacular works was not very desirable. It turns out that despite the insistence on the original manifestations of faith, most Protestant-oriented nobility gradually leaned towards humanist education and active social life and representation, ${ }^{39}$ while being subordinate to the 'duty of luxury'. ${ }^{40}$ Ambitious forms of sepulchral representation were soon adopted by small nobility and townspeople, who sometimes preferred stone or painted epitaphs, as exemplified by the sandstone epitaphs of Michael (d. 1585) and Anna (d. 1587) of the Hagendorns in the cemetery church in Mohelnice, or that of Jiří Thaller (d. 1570) 
in the Church of St Maurice in Olomouc or epitaphs in Moravská Třebová. ${ }^{41}$

It is noteworthy that in Moravia whole-figure tombstones were occasionally used by townsmen already at the end of the first third of the sixteenth century which was symptomatic for the growing social position and cultural confidence of this social class. Its early examples in the Moravian sepulchral sculpture include the small tomb memorial of the son of the Viennese merchant Johann Eibenstock (d. 1524)
(Fig. 6).A latter examples were the tombstones belonging to the Olomouc episcopal circle, which were commissioned by the local priest Valentin Niger (Schwarz) during his life and for his deceased father Wenceslas (Fig. 8). ${ }^{42}$ However, those townsmen who sought to emphasise their prestige and promotion on the social ladder sometimes chose new, directly exclusive types of posthumous representation. An example for this is the unique construction of the tomb of the ennobled townsman Václav senior Edelmann of Brosdorf, built

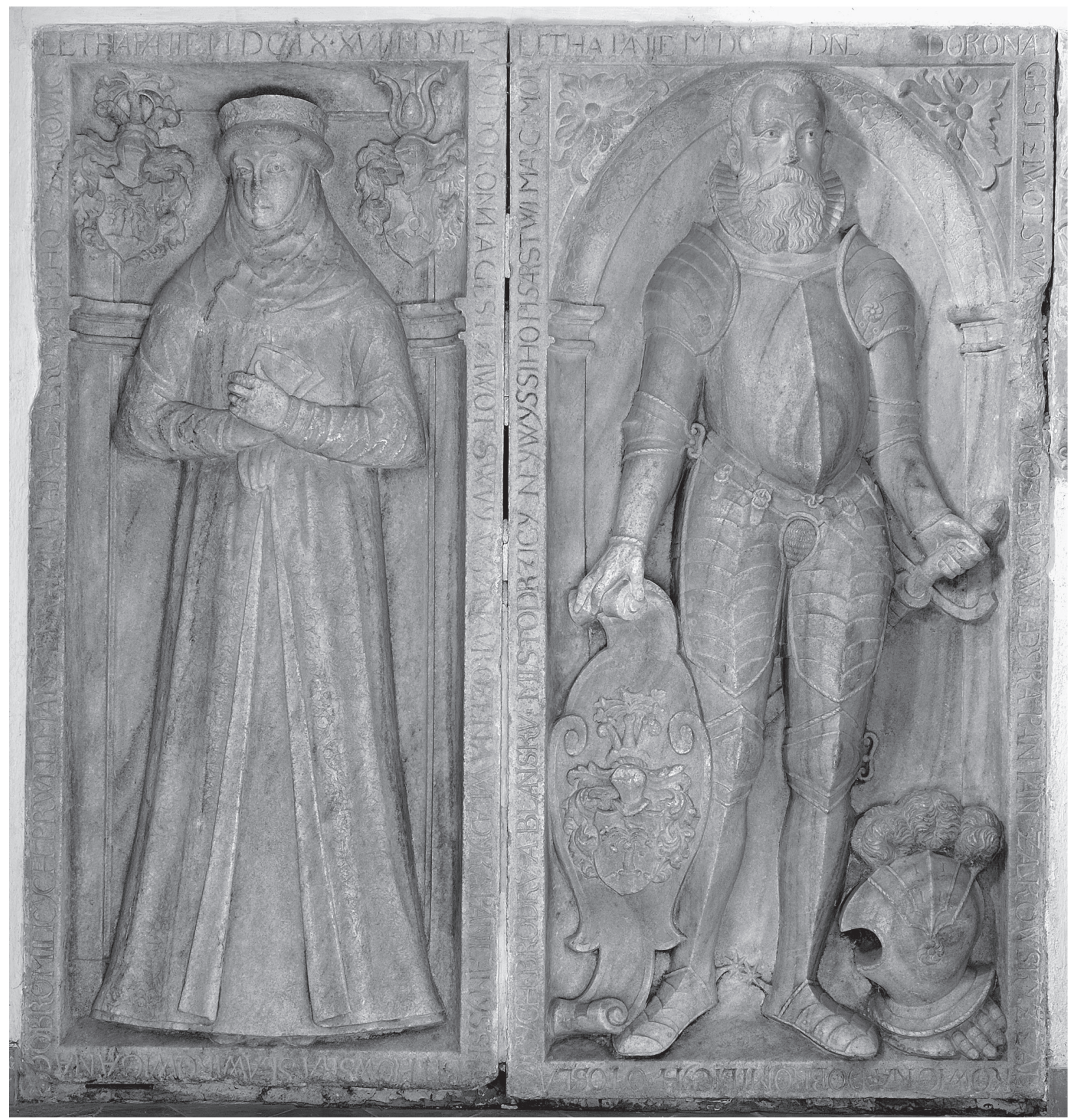

Fig. 34. Master of the tombstone of Jan Žalkovský of Žalkovice in Dobromilice: tombstone of Jan Žalkovský of Žalkovice (made after 1609) and of Anežka Bítovská of Slavíkovice (d. 1609). Dobromilice, All Saints Church (photo: Petr Zatloukal) 


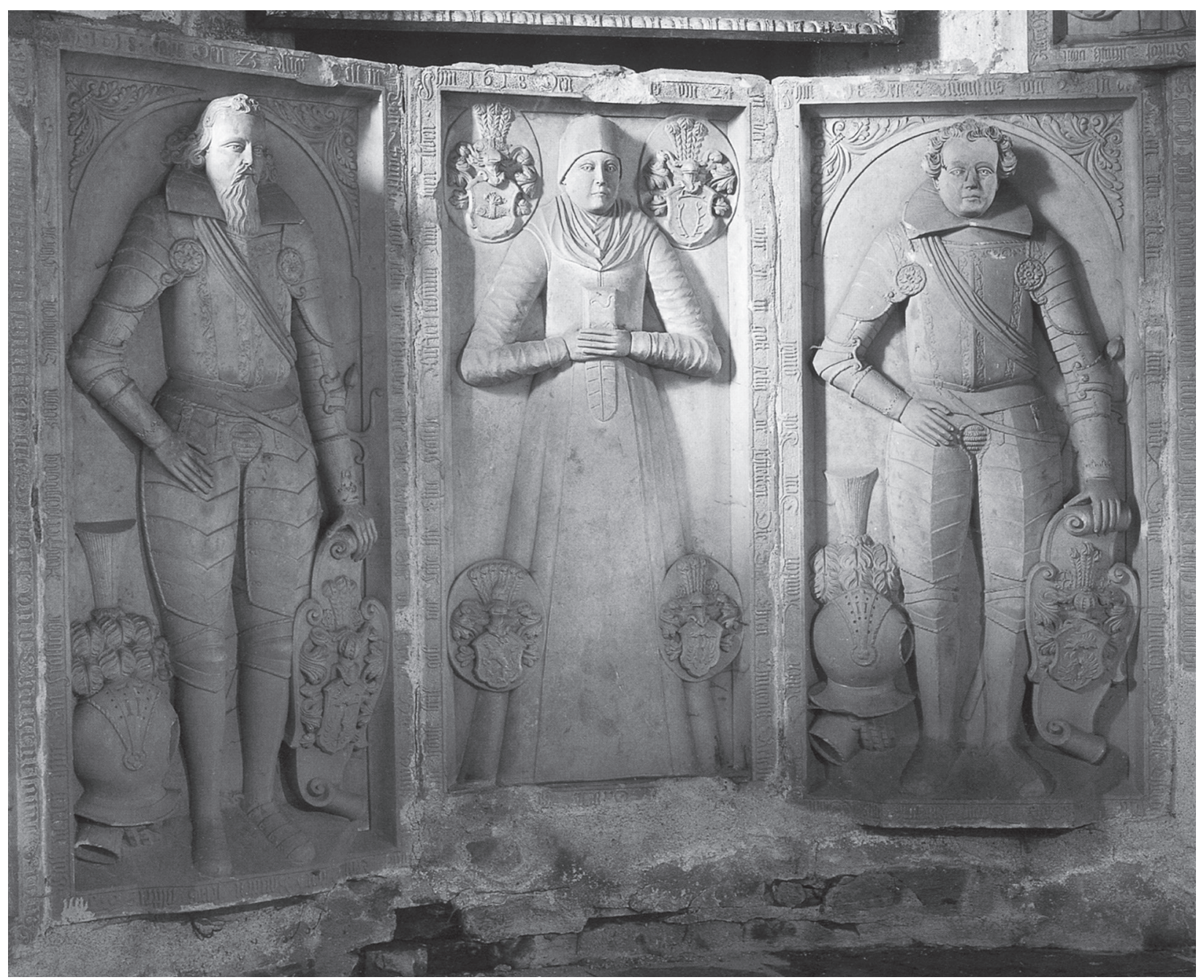

Fig. 35. Master of the tombstones of the Litvic family of Staré Roudno: tombstones of Jan Litvic of Staré Roudno (d. 1618), Jan Jiří Litvic of Staré Roudno (d. 1618) and Alžběta Glaubicová (d. 1618). Moravská Třebová, lapidary at the funerary Church of the Finding of the Holy Cross (photo: Miloslav Kužílek)

in 1572 at the Church of St Maurice in Olomouc. ${ }^{43}$ The patrician and the newly formed intelligence, both from the aristocratic and bourgeois classes, rarely accepted the so-called semi-figural portrait tombstones. Among the preserved works we can mention examples remarkable for their artistic quality, such as the tombstones of the Italian architect Leonardo Garo de Bisono (d. 1574) (Fig. 37) in Moravský Krumlov, and the one of the Hustopeče burgrave Fabian Räbl (d. 1597), currently in Klobouky. ${ }^{44}$

Protestant endeavours to express a more intimate relationship with Christ and at the same time a similar anti-Reformation tendency (based on the Trident Council) brought further changes to the sepulchral development, where the emphasis on personal and gender representation gradually replaced the strengthening of intimate devotion and private adoration, as suggested by tombstones with a figure priant. They appear in the Protestant aristocracy, as evidenced by the tombstones of Bartholomew and Bedrich of Žerotín in Napajedla (Fig. 16), and also in the circles of Catholics, as the diffused or multiplied tombstone monument ${ }^{45}$ of Kašpar Pruskovský of Pruskov (d. 1603) in Hradec nad Moravicí, the court council of Emperor Rudolf II shows.

In the sepulchral works of the monitored area, the figures of the deceased are depicted most often as living, standing with their eyes open either in a quiet pose or with a more marked indication of movement. In the composition of our Renaissance tombstones, a combination of dual space and time where a figure is clearly standing on a plinth, leaning with their hand on a sword or helmet, but having his eyes closed and head resting on a pillow is not very frequent. This form was created (inter alia) by transferring the characters of a figure on the cover slab above the tomb to 


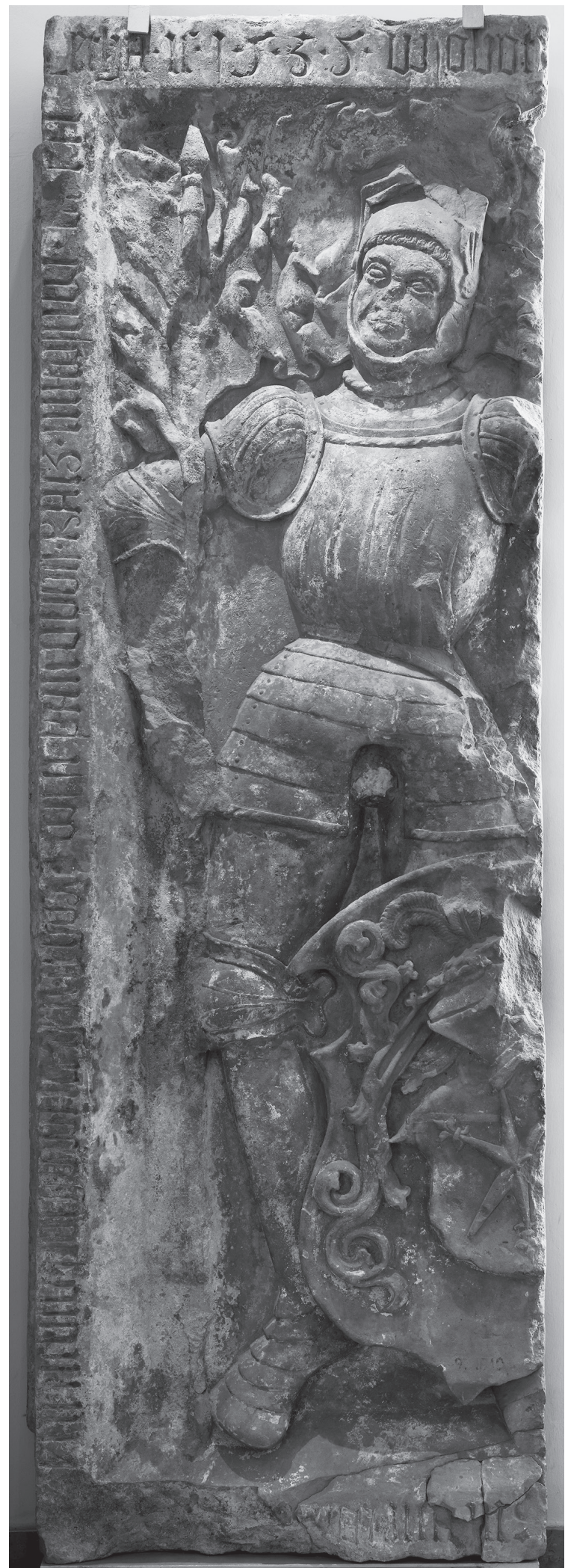

Fig. 36. Unknown master: Olomouc episcopal court circle: fragment of the tombstone of Kryštof Kropáč of Nevědomí (d. 1535) from Skalice. Budapest, Hungarian National Museum, exhibition of Medieval Lapidary (photo: József Rosta, Hungarian National Museum, Budapest)

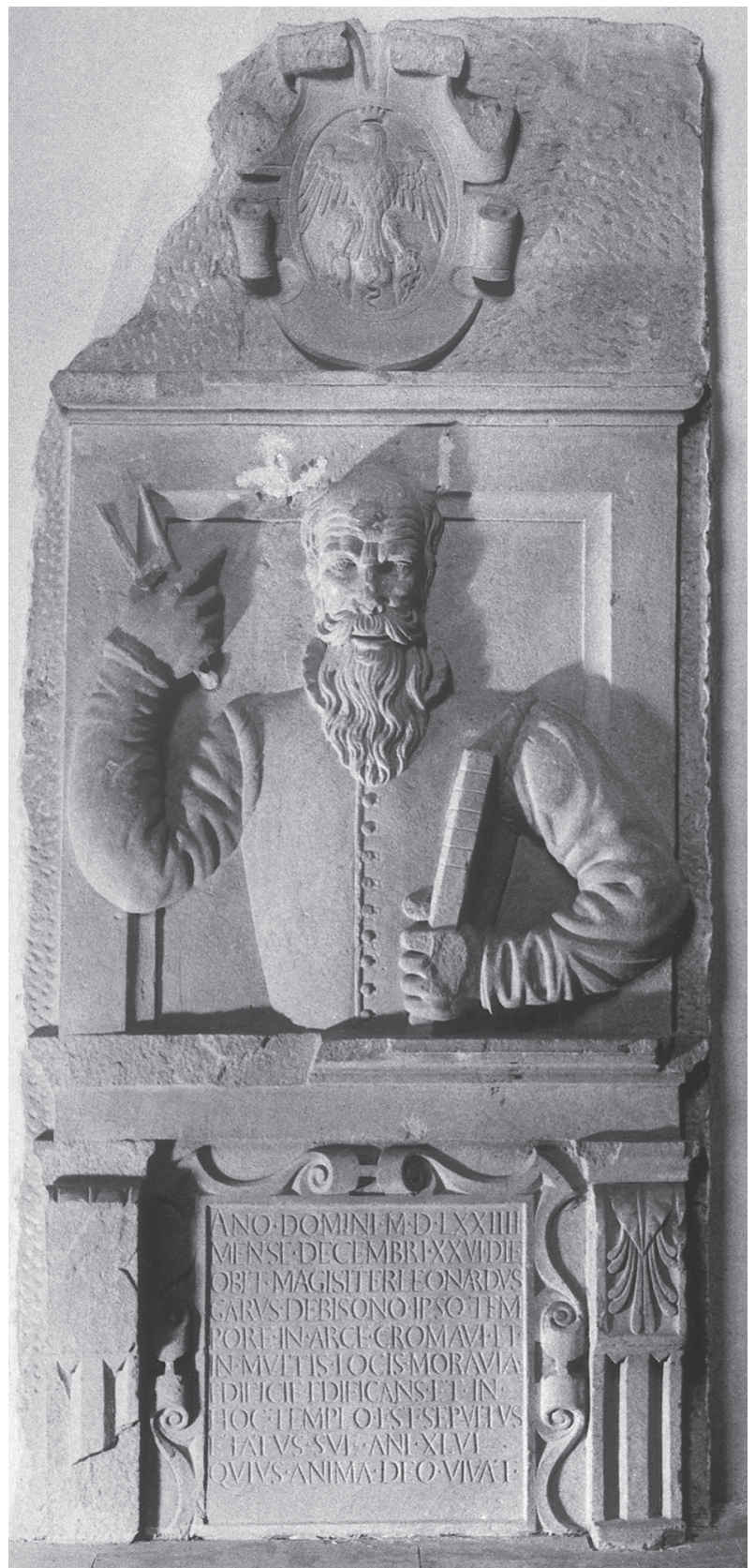

Fig. 37. Unknown master: tombstones of the Italian architect Leonard Garo de Bisono (d. 1574). Moravský

Krumlov, All Saints Church (photo: Josef Kristián)

the wall composition with a tombstone, depicting the deceased in a blissful pose awaiting salvation. However, it is necessary to take into account the influence of Neo-Platonism and Italian sepulchral sculpture, in which figures with closed eyes are frequent.

The compositional structure of the tombstone with the standing figure moves from the late Gothic period to the Renaissance works in morphological or stylistic shifts. These are evidenced not only by differences in the conception of each author, but by changes 


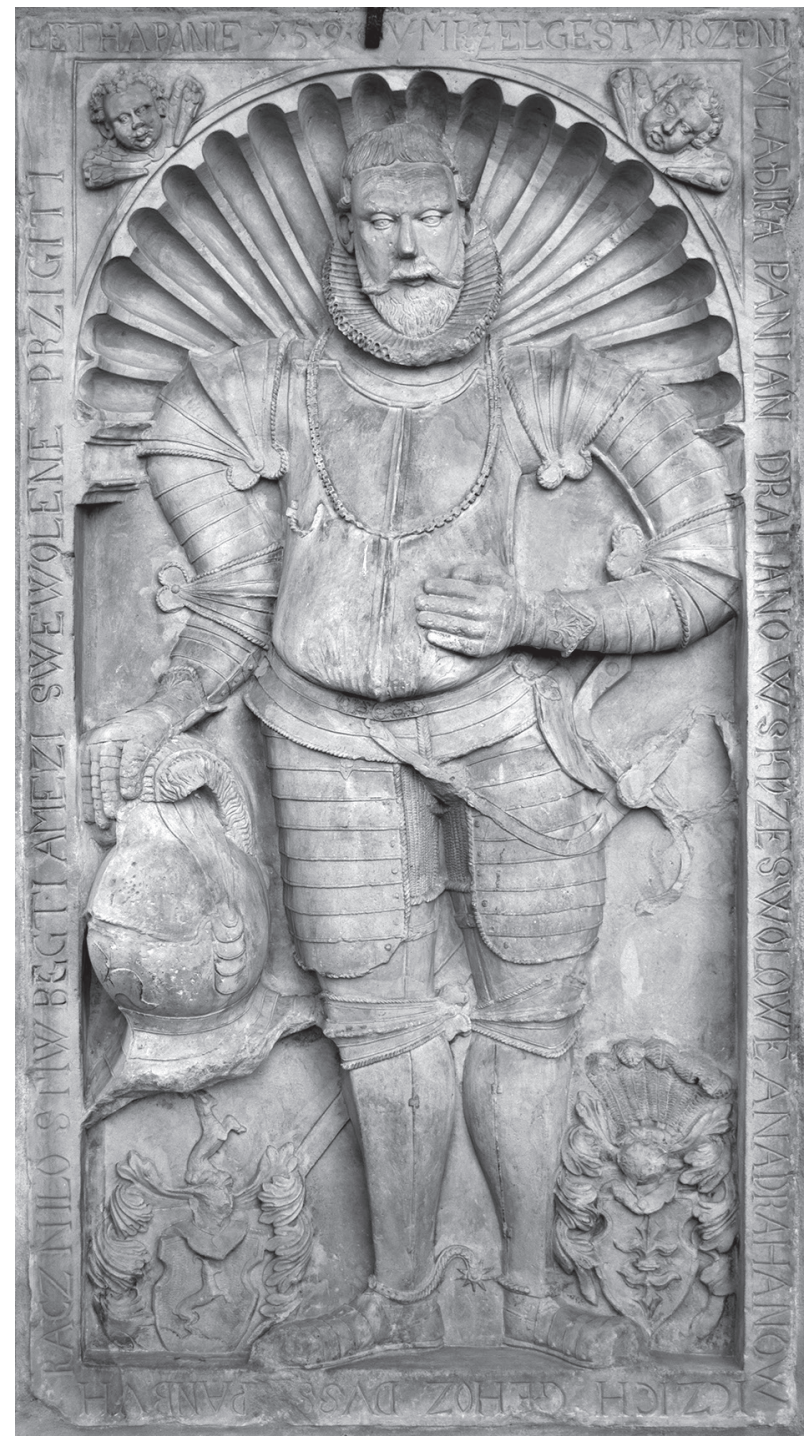

Fig. 38. Master of the males' tombstones: tombstone of Jan Drahanovský of Stvolová (d. 1590). Drahanovice, Church of St James the Greater (photo: Jakub Dlabal)

in the creator's craftsmanship, or by the various extend of the workshop workers' participation in the work, by the effect of designs, period characteristics and fashion that are reflected in details and the overall concepts. Despite workshop stereotypes, the Renaissance masters were influenced by the desires and demands of the buyers and respected the representative aspects given not only by the changes in armour and weapon depiction, but also by the demands and changes of contemporary clothing and fashion.

In the Moravian Renaissance sepulchral sculpture not only the symbolic animal under the feet of the deceased - the banner held by the knight - but also the medieval canon of strict frontality, Gothic naturalism in capturing the facial parts and broken folds of

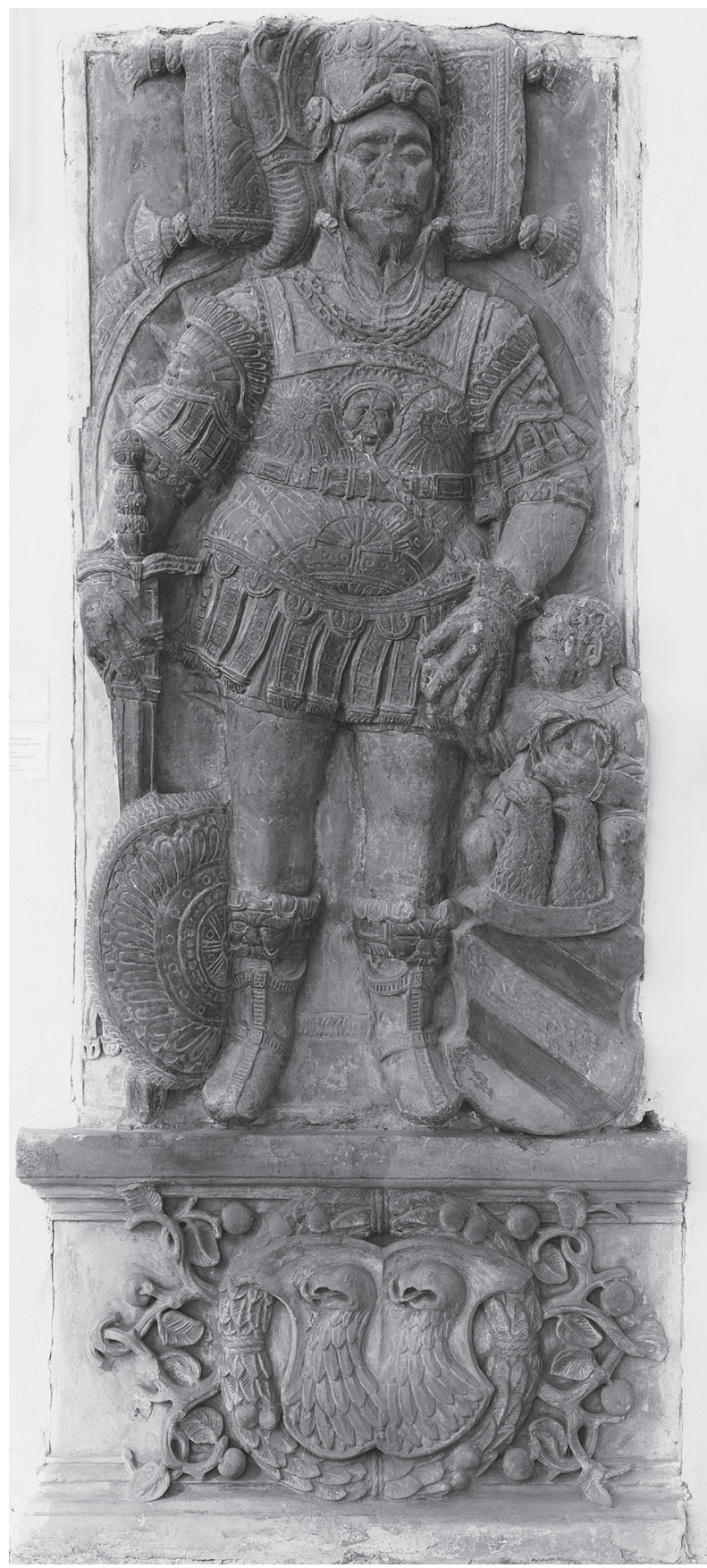

Fig. 39. Master PH: tombstone of knight Adam Štolbašský of Doloplazy (d. 1527, after 1529). Olomouc, the cloister of Dominican Monastery (photo: Petr Zatloukal)

the textile robe disappear rapidly so that they can be replaced by increasing concentration on the depicted person by way of approaching the individualised portrait and proportions of the character. There are also details of the real environment such as spatially graded and architecturally shaped niches, helmets, tapestries in the background, hints of terrain and natural motifs. The figure itself is becoming the centre of the sculp- 


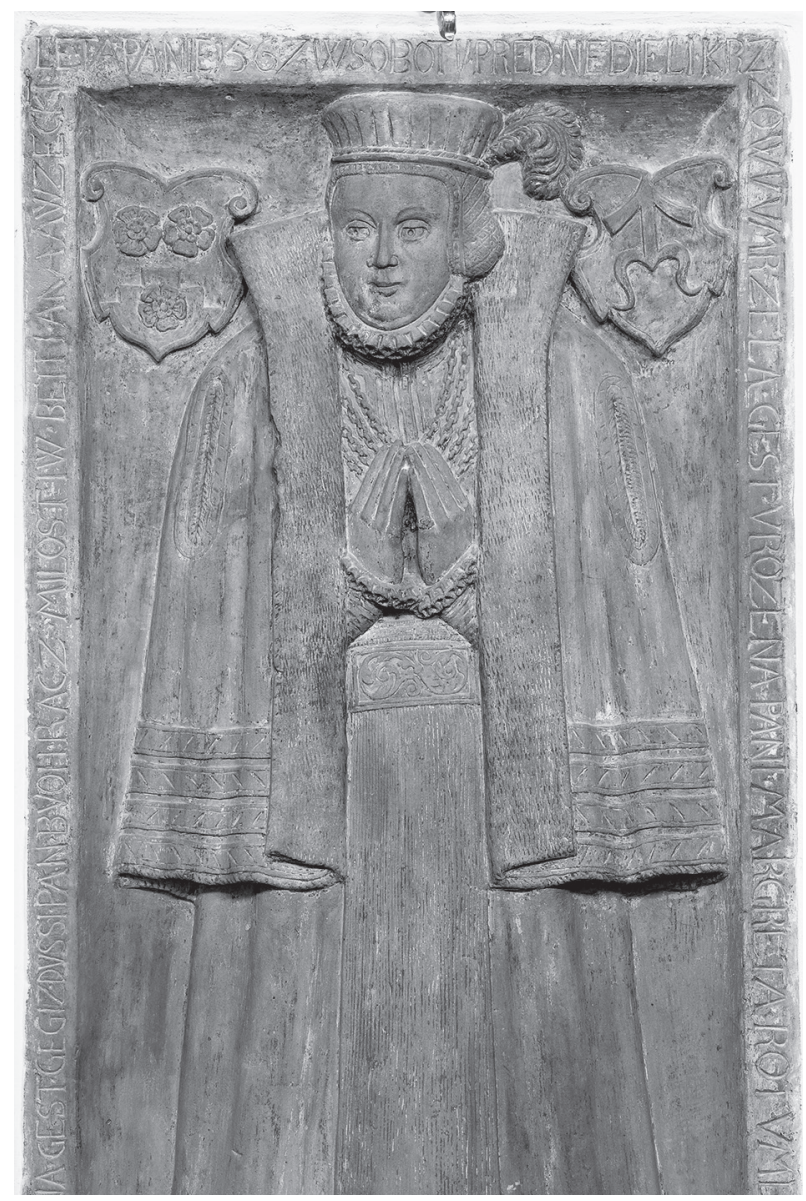

Fig. 40. Master of the tombstones of the family of Petr Vlk of Konecchlumí: tombstone of Markéta Rotmberková of Ketř (d. 1567). Slavkov, Church of St Anna (photo: Petr Zatloukal)

tor's or stonemason's interest depicted in its plastic statuesque and natural movement.

The development that began in the Middle Ages, first as a mere personal identification represented by a coat of arms and inscription in our period already attempts to represent the personality of the deceased. It can be illustrated in the Moravian material by many examples, which create a unique set of distinctively conceived depictions of representatives of contemporary Renaissance society. The stimulating conditions of this trend can be seen in the atmosphere of post-confessional Christianity and Christian humanism, which accelerated the adoption of Renaissance models. ${ }^{46}$ However, despite the various possibilities of depicting an individual, in the sepulchral sculpture of the period under review, rather than with a realistic portrait, we often encounter an attempt at individualisation within the inadvertent author's stylisation or the necessary idealisation. It was required by the nature of sepulchral work, to resist transience and had social as

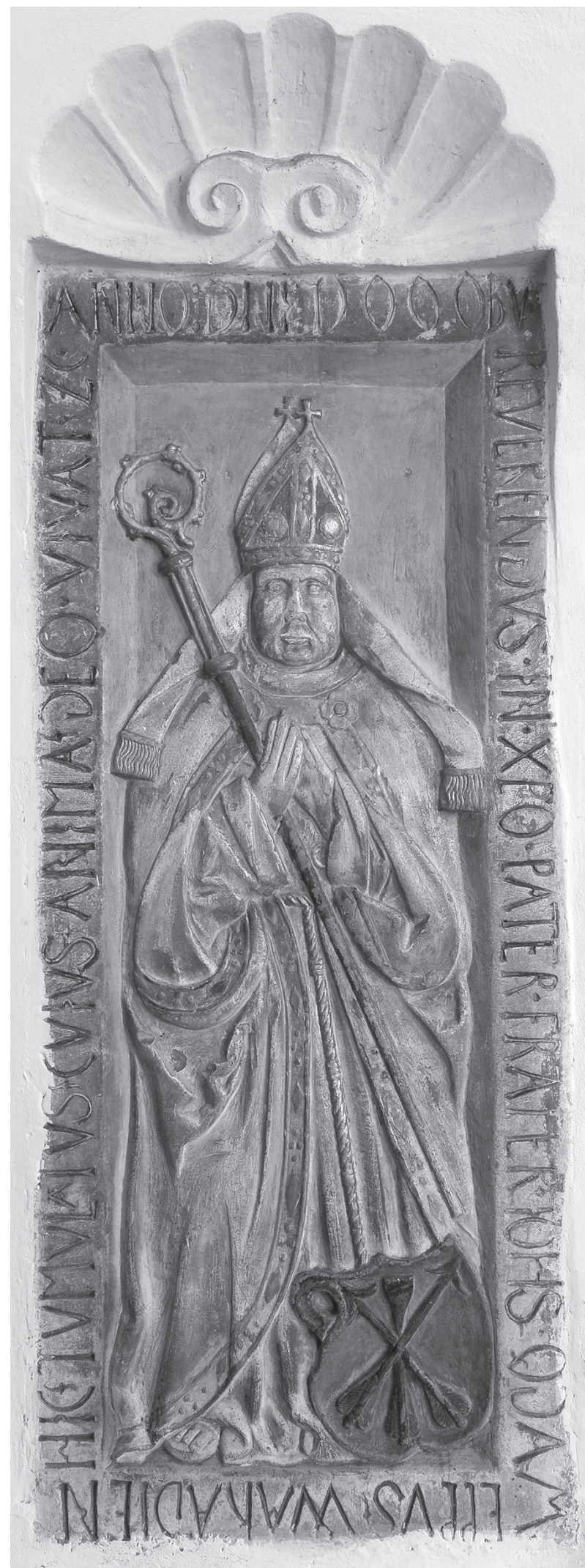

Fig. 41. Unknown master: tombstone of the bishop of Oradea and administrator of the Olomouc diocese Jan Filipec (d. 1509). Uherské Hradiště, Franciscan Church of Virgin Mary (photo: Petr Zatloukal) 
well as representative dimension. In the best works; in the fine tombstone of Jindrich of Lomnice and in Meziříčí (d. 1554) (Fig. 10) or the Dobromilice slab of Matyáš Žalkovský of Žalkovice (d. 1590) (Fig. 26) we find an effort to approach a sculptural realistic portrait, which in some sense replaces the lack of portrait works in Moravian Renaissance painting.

At the same time, however, we observe some contradictions in the concept of characters in the wholefigure sepulchral monuments, that is, surviving dualism. A realistic, portrait effort concentrates on a face that reflects human individuality, but other parts of the body tend to be treated more generally according to proven and established models, revealing a tendency to express stylism and idealisation. In addition to the above mentioned examples, it is noticeable on the tombstones of Anna Litvicová of Staré Roudno (d. 1551) in Jemnice (Fig. 10), or Anna Valkounová of Šarov (d. 1571) in Krumsín.

The monitored material proves that during the realisation of the sepulchres the authors mostly varied the acquired index of typological, figural and ornamental forms, contemporary models and patterns. The basic scheme of a figural tombstone with a standing figure was therefore tenaciously maintained in Moravia and Czech Silesia throughout the sixteenth and early seventeenth centuries. However, the character's position had been altered in a variety of ways against the traditional frontal concept. For the early phase of sepulchral production (roughly the first half of the sixteenth century) the striking preference of a three-quarter turn is not only in a humble prayer gesture, ${ }^{47}$ but also in an increasingly dynamic movement of a confident knight. Inspired by the commemorative memorial of Arnošt Kužel of Žeravice (d. 1508, dated 1524) (Fig. 9), a type of knight's tombstone which was conceived and spread in the work of the so-called Master $\mathrm{H}$, expressed ideas about the representation of Moravian nobility not only by way of male and female tombstones but also children's in the second third of the sixteenth century. ${ }^{48}$ In the particularity of its formation and decorative style, the Moravian sepulchral work achieved its specific domestic expression, whose influence also radiated to Silesia.

In the following period, the momentum of the characters calmed down somewhat, but the static frontal/hieratic position, as we can observe on the numerous Silesian, Polish or Slovak tombstones, rather widened the range of possibilities used. In the further development the male characters - especially in the works attributed to the Master of the tombstone

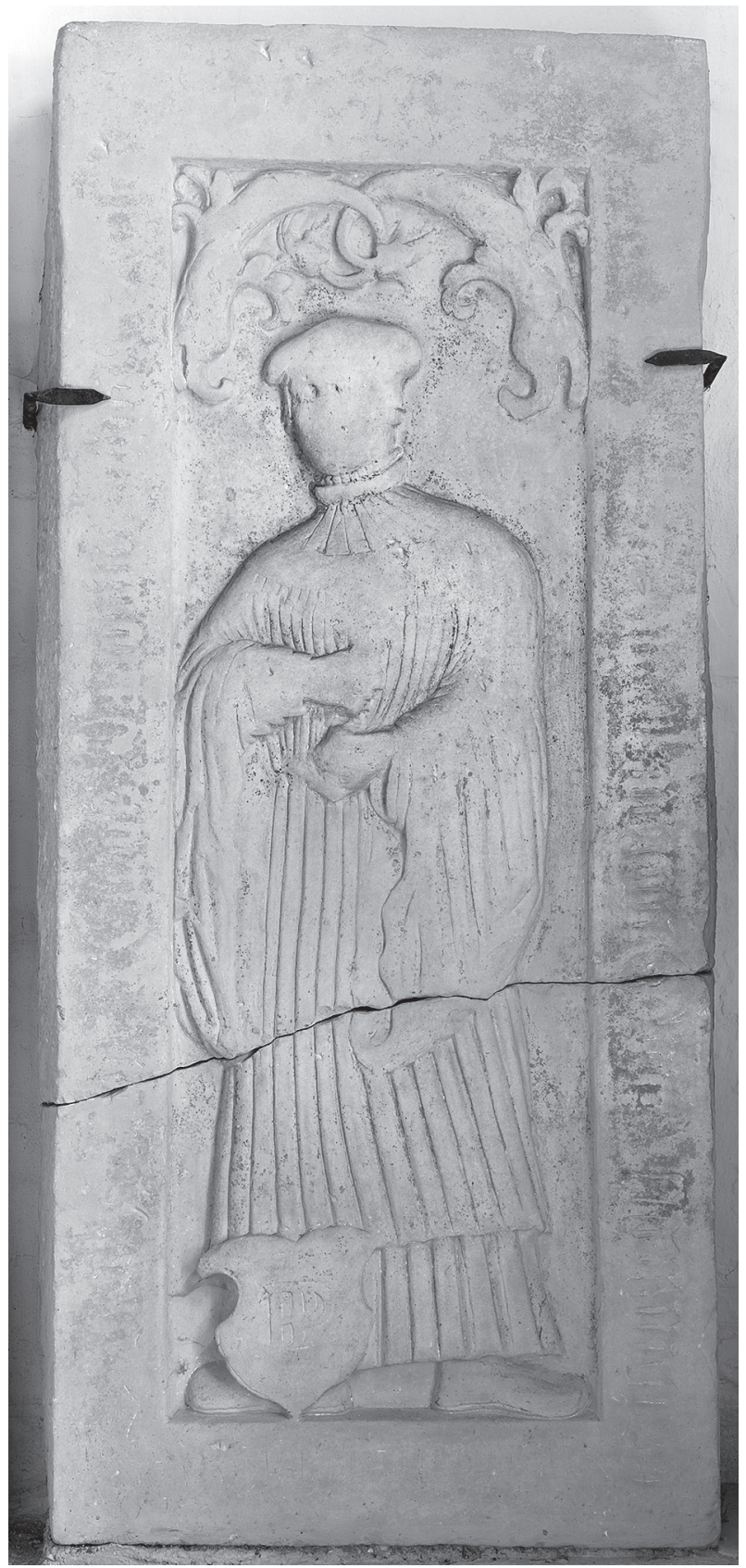

Fig. 42. Unknown master: Olomouc episcopal court circle, tombstone of an unknown priest (made around 1530). Vyšehorky, All Saints Church (photo: Petr Zatloukal)

of Václav Berka of Dubá and Lipý and his workshop - were mostly conceived in a moving contra-post resembling a dance posture, sometimes with a hint of making a step forward and with emphasised gestures indicating the interaction of the depicted characters. The dynamic attitude emphasised by the use of the gesture of the 'renaissance elbow' gave the characters an expression of self-confidence and determination. ${ }^{49}$ In the last phase of the sixteenth century, markedly influenced by Mannerism the figures, (especially the 


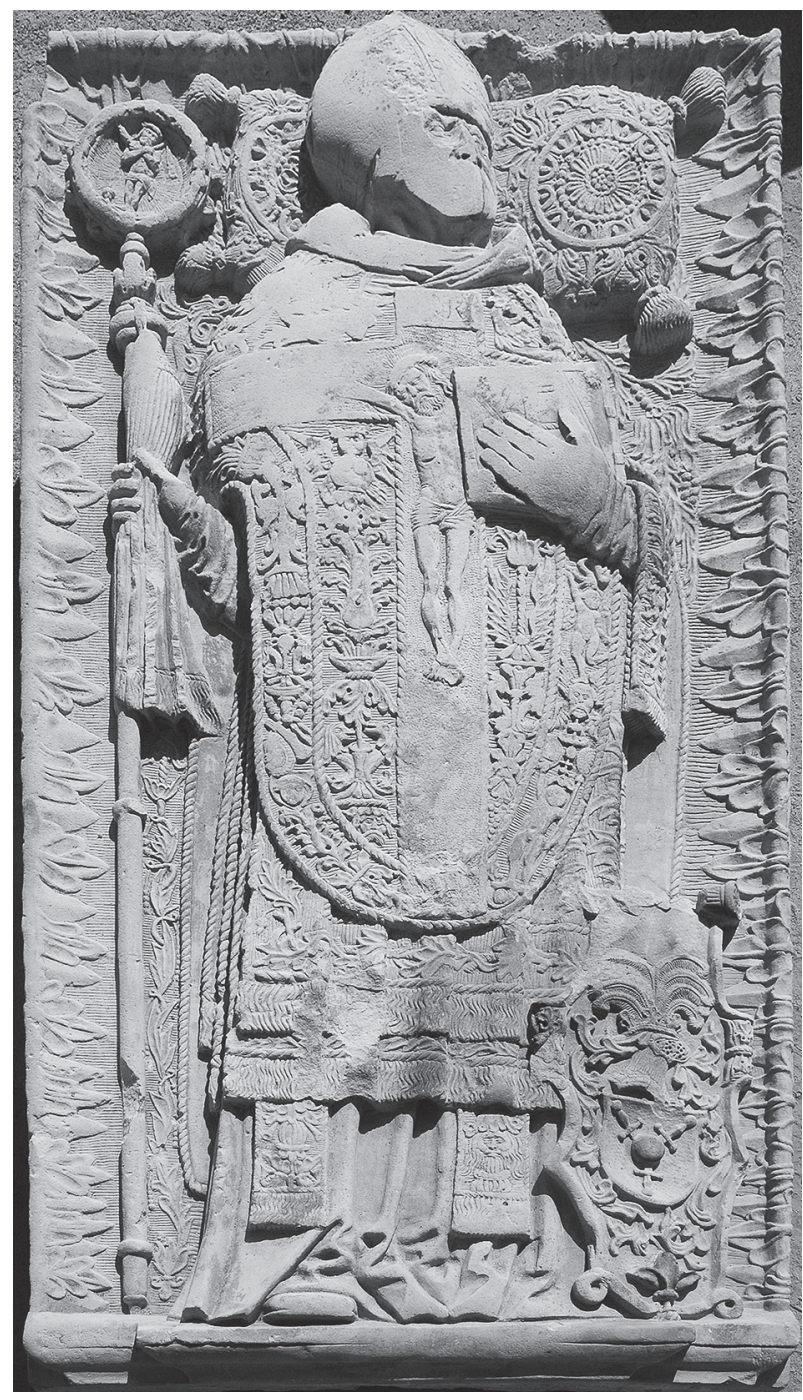

Fig. 43. Master PH (?): tombstone of Wrocław's auxiliary bishop Jindřich Sup of Fulštejn (d. 1538). Bohušov, Church of St Martin (photo: Jakub Gajda)

male ones) show noticeable and very sophisticated deformations or rotations of individual parts of the body, as on the tombstone of Jan Drahanovský of Stvolová (d. 1590) in Drahanovice (Fig. 38). On the other hand, the female characters, in addition to the relatively early examples of the three-quarter turn of the type of eternal prayer (as on the already mentioned Jemnice piece [Fig. 10]), were dominated by more conservative, static frontal attitudes with hands clasped to prayer, folded on the belly, or with the baby in their arms. However, even they did not avoid Manneristic stylisation and deformation, such as the depiction of female and child characters in the work of the Master of males' tombstones. We more often meet figural tombstones belonging to the nobility, related to the social status of this social class showing, that in addi- tion to heraldic identification, representative clothing also played an important role. Different tendencies and strategies can be observed on the representations. One is a certain conservativeness in adherence to traditional models, that is, depicting male characters as knights in full armour, and the other is the depiction of clothing taking into account period fashion and changing life views.

Descriptive interest in the appearance of clothing, appearing before the mid-sixteenth century - for example in the work of Master PH and Master $\mathrm{H}$ - had developed in accordance with contemporary aesthetic feelings in the likeness of miniature depiction of representative motifs, especially ceremonial armour. In this context, it is important to recall in our countries the completely unusual use of ceremonial costume tournament armour alla Romana on the Olomouc tombstone, probably a fragment of the tomb of Adam Štolbašský of Doloplazy (d. 1527, after 1529) (Fig.39). The antique inspiration was used to strengthen secular fame in the portraits of significant men, though updated forms of the all'antica style not only revived the thematic register of military and ruling glory, but were adapted by Christianity and applied in the liturgical and moral spheres. ${ }^{50}$

In connection with the transformation of European plate armour art, the character of armour was also changing. On the tombstones, it was gradually assuming the role of an external attribute proving the peerage, or being a reminder of a war episode in the life of the deceased, as evidenced by the armour, a helmet on the head and a war hammer on the Slavkov tombstone of Petr Vlk of Konecchlumí (d. 1572) (Fig. 28). In the second half of the sixteenth century, civilian clothing also appeared on the tombstones of nobles, signalling changes in the expression of traditional knightly virtues and the acceptance of a new lifestyle. It is usually treated with all the attributes of opulence and luxury. In addition to the Boskovice tombstone of Proček Morkovský of Zástřizl (d. 1579) (Fig. 18), the most remarkable example in this respect is the Cholina tombstone of Jan Zoubek of Zdětín with his son (d. 1585) (Fig. 23); a good example of female tombstone is the one in Slavkov belonging to Markéta Rotmberková of Ketra (d. 1567) (Fig. 40). In the second half of the sixteenth century, the effects of Spanish fashion, which penetrated mainly through the contacts of the Moravian nobility with the Habsburg imperial court, are also reflected in the clothing of both sexes. The detailed descriptiveness of the decorative elements of the garment was gradually replaced by a stricter, more concise style, a more gen- 


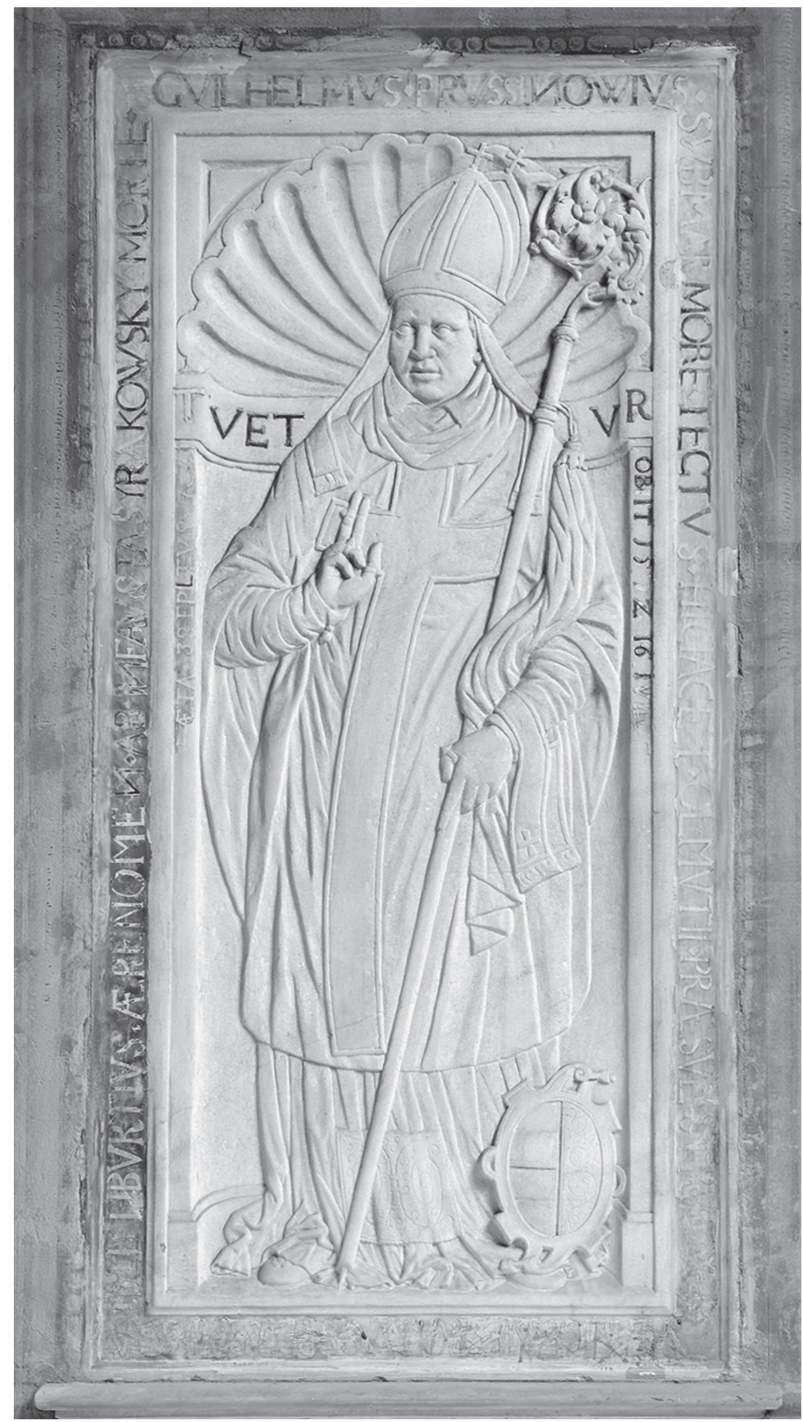

Fig. 44. Master of the tombstone of Václav Berka of Dubá and Lipý: tombstone of Olomouc bishop Vilém Prusinovský of Víckov (d. 1572), the founder of Jesuit College in Olomouc. Olomouc, Church of Our Lady of the Snows (photo: Petr Zatloukal)

erous and summarizing concept, in which plastic and optical qualities played a significant role, particularly in depicting volumes and properties of materials, as we can see on the clothes of lady Kunka of Korotín depicted together with her husband on the Boskovice tombstone (Fig. 27). In the character of women's clothing, confessionality could also manifest itself. Represented by the tombstones of noble women claiming the adherence to Protestant churches, whose clothing is sometimes surprisingly simple, avoids luxury, and despite the sepulchral representative mission it is not different from the townsmen's.

The unified basic concept was also characterised by figural tombstones of bishops and other ecclesias-

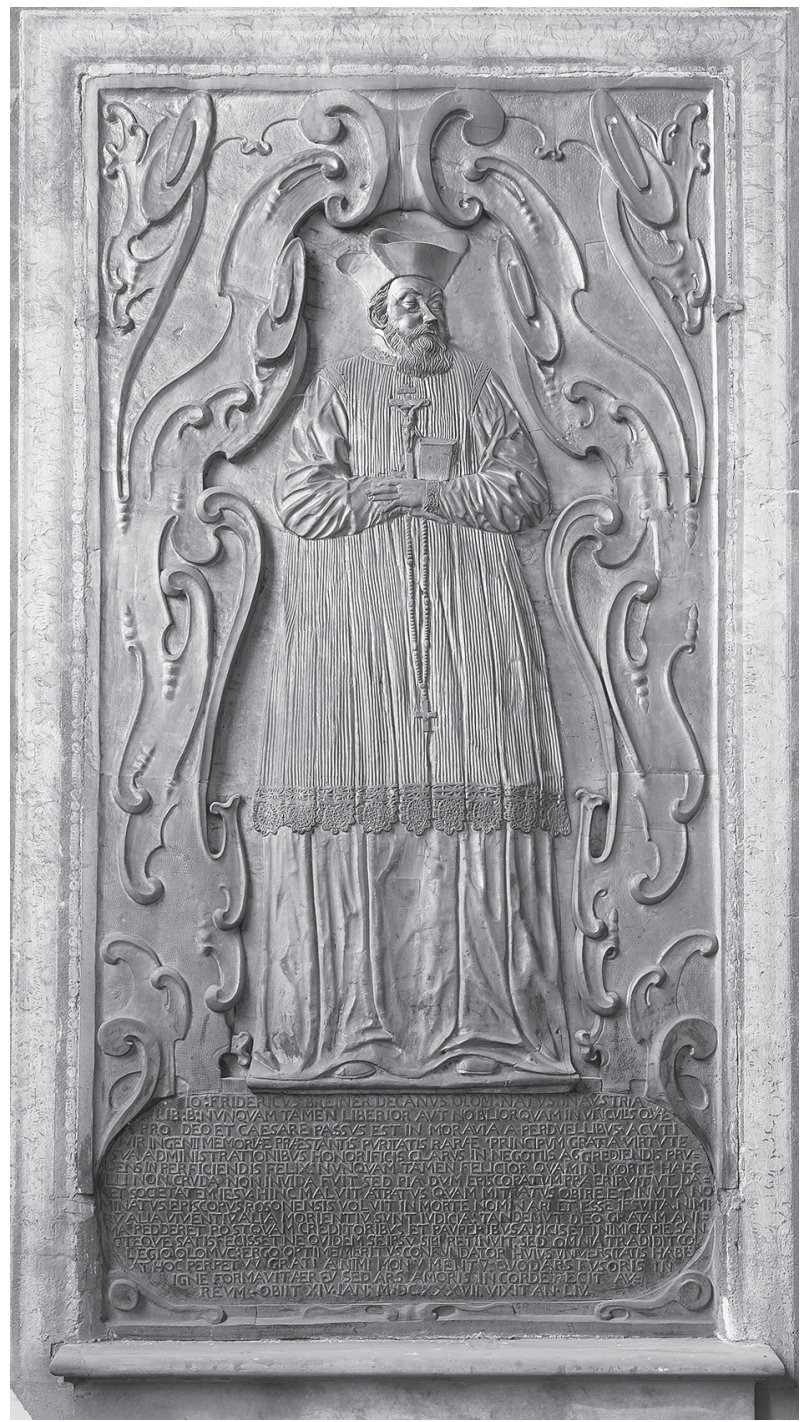

Fig. 45. Unknown sculptor and Jiří Zwerger: tomb monument of capitular dean Jan Bedřich Breiner (d. 1637, made between 1637-1642). Olomouc, Jesuit Church of Our Lady of the Snows (photo: Petr Zatloukal)

tical dignitaries. However, despite the importance of the diocese of Olomouc, the number of such pieces was negligible in Moravia and in the adjoining part of Silesia.

The traditional depiction of a bishop in robe with a mitre and a crosier is marked by significant differences due to different stylistic and authorship provenance, and finally by the technique of execution. Gothic features can be still seen on the tombstone of the bishop of Oradea (Nagyvárad in the former Kingdom of Hungary, today Romania) and administrator of the Olomouc diocese Jan Filipec (d. 1509) in Uherské Hradiště (Fig. 41), the motifs of which combine references to individual stages of Filipec's life. In addition to the insignias of his 


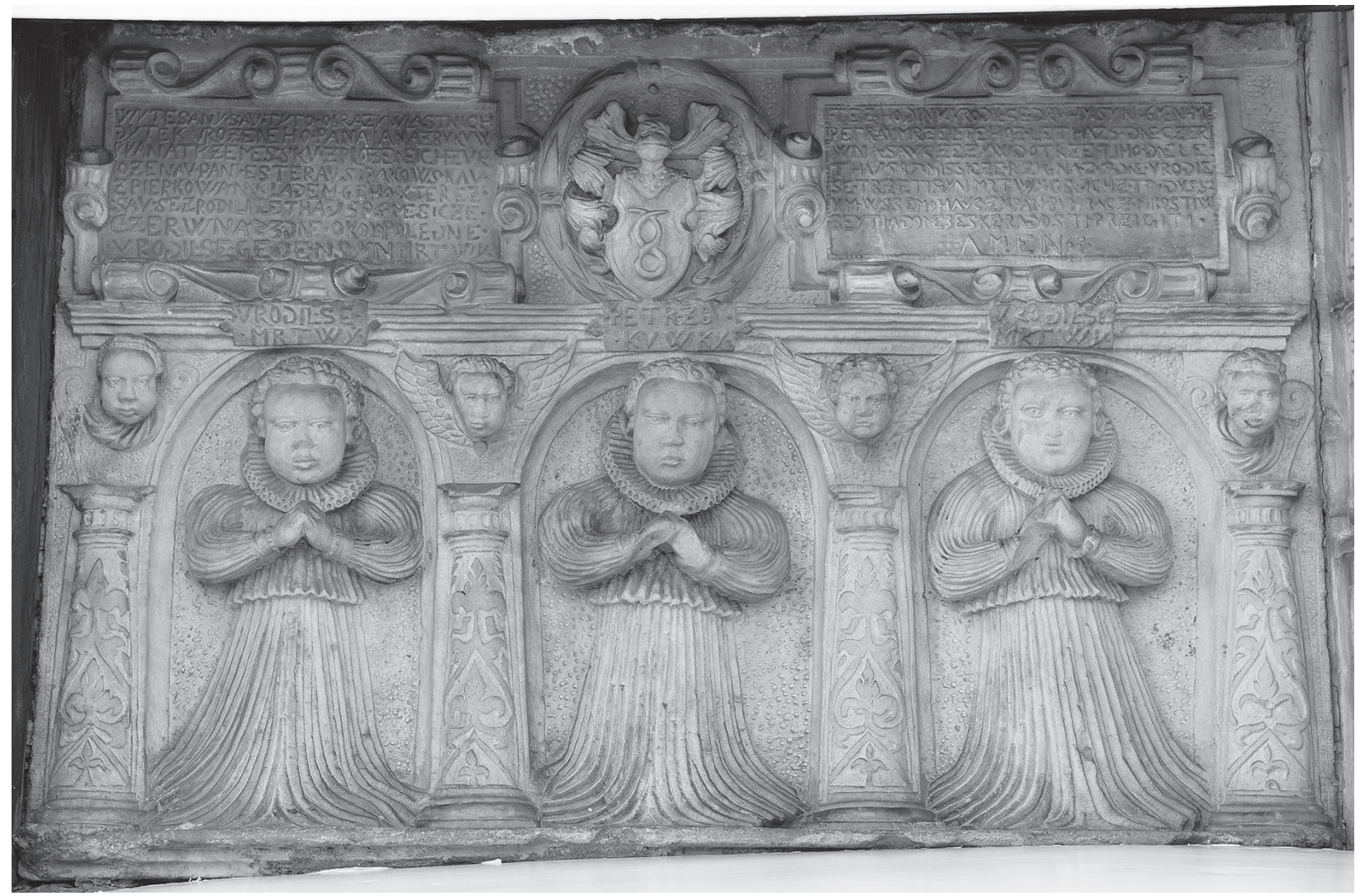

Fig. 46. Master of the males' tombstones (workshop): tombstone of Petr Bukůvka of Bukůvka and his stillborn brothers (d. 1586 and 1587). Dolní Studénky, Church of St Linhart (photo: Petr Zatloukal)

episcopal rank (in 1476 he became bishop of Oradea) and his coat of arms, a Franciscan robe belted with a three-knot rope cingulum and his bare foot in a sandal also points to his later monastic status. The appearance of the monument does not take into account Filipec's previous dignity. Apart from exceptional tombstones of clergymen in Mohelnice and Vyšehorky (Figs. 7, 42), the quality of workmanship and the distinctively decorative characteristic of all'antica is also remarkable on the early Renaissance tombstone of bishop Jindrich Sup of Fulštejn (d. 1538), found surprisingly during a 1999-2000 (Bohušov) Czech Silesian archaeological research (Fig. 43). ${ }^{51}$

The descriptive detail and focus on the decorative effect is characterised by a bronze tombstone of bishop Marek Kuen (d. 1566, eps. 1553-1565) in the Cathedral of St Wenceslas in Olomouc. The imported work of Nuremberg provenance - signed by coppersmith Hans Straubinger ${ }^{52}$ - is absolutely unique in Moravian production, having all the attributes of a precise, formally sophisticated Renaissance metalwork.

The tombstone, perhaps only the upper part of the original monument of bishop Vilém Prusinovský of Víckov (d. 1572), the founder of the Jesuit College in Olomouc, located in the Church of Our Lady of the Snows in Olomouc is less decorative, but all the more vivid. It shows an unusually low relief of white Parian (?) marble, complemented with a circular inscription consisting of inlaid bronze letters, in which the words ... sub marmore ... emphasise the use of precious material (Fig. 44). ${ }^{53}$ The tombstone was commissioned by the executors of the last will, namely the bishop's sister Alena and her husband Ctibor Syrakovský of Perrkov, from 1579 the highest scribe of the Margraviate of Moravia. The Manneristic bronze tomb monument of the Olomouc capitular dean Jan Bedriich Breiner (d. 1637) in the same Jesuit church of Olomouc (Fig. 45) ${ }^{54}$ was made between 1637/1638 and 1642 , striking with its conceptual polarity based on the traditional Renaissance typology of the figural part, is already heading towards the Baroque period. It was cast in the Olomouc workshop of the coppersmith Jiři Zwergr, who received his payment in 1642.

The formal morphology of figural tombstones, whether laid into the floor of church buildings or fitted vertically often differ in detail, but their overall concept is always based on some basic variations of the established patterns. On the surface of a stone 
slab, the figure is placed in a more or less plastically indicated space, mostly in an architectonically structured niche. The emphasis placed on the character and its self-confident statuarity - which was associated with Renaissance rationalism and humanistic individualism - tended towards a greater endeavour for a more realistic concept of this space. The aedicular framework, which is not only a specific formal value in Renaissance sepulchral sculpture, but also bears the symbolic meaning of the Christian triumph of life over death, is, for example, part of the tombstone of Wolf Dietrich of Hardek in Letovice (d. 1564, dated 1566) (Fig. 14). The tendency to place the figure within a monumental architectural framework that connotes portal architecture, combining the Renaissance legacy of ancient triumphalism of public monuments with Christian triumph had intensified from the second half of the sixteenth cent ury. Remarkable evidence of this semantic connotation is the aedicules framing the slab with the figures of the deceased, con- nected with epitaphs in the extensions in Bartošovice (Figs. 31-33).

In the sepulchral sculpture of the monitored area, the figures are most often carved on separate stones. The architecturally accentuated combination of these simple boards of spouses or relatives creates so-called associated tombstones such as the Boskovice memorial of Jaroš Morkovský of Zástřizl (d. 1583) and Johanka Drnovská of Drnovice (d. most likely before 1589) (Fig. 19). However, we also find tombstones depicting more people, especially married couples on one slab, such as the tombstone of Václav Sedlnický of Choltice (d. 1588) and Kateřina Bruntálská of Vrbno (d. 1586) in Bartošovice (Fig. 31), or the tombstone of Václav Morkovský of Zástřizl (d. 1600) and Kunka of Korotín (Fig. 27). Also relatives are being depicted in the same slab, often mother, but sometimes father and child, such as Jan Zoubek of Zdětín with his son (d. 1585) in Cholina (Fig. 23), or the deceased siblings Petr Bukůvka of Bukůvka and his two brothers

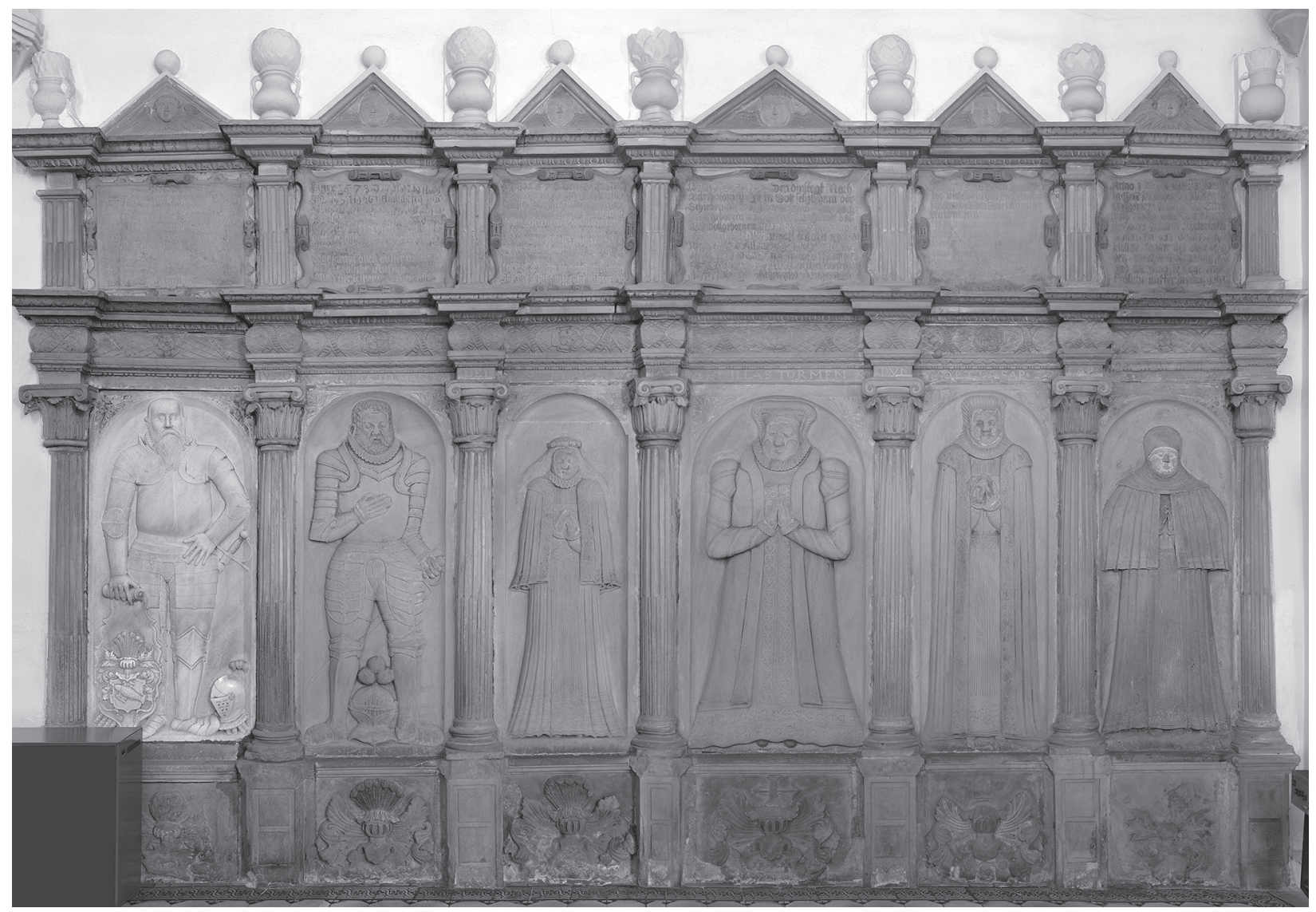

Fig. 47. A joint sepulchral monument of the family members of Ondřej Bzenec of Markvartovice and of Poruba, the owner of Klimkovice estate. Klimkovice, Church of St Catherine. From left to right: Kryštof Bzenec (d. 1600), Fabián Bzenec

(d. 1578), Anna Bzencová (d. 1576), Barbora of Vrbno (d. 1580), Kateřina Děhylovská of Děhylov (d. 1598),

Ester Tvorkovská of Kravaře (d. 1596). Four medium-size figural tombstones are the work of the Master of the tombstones in Sedlnice, the works on the sides were carved by unknown masters (photo: Petr Zatloukal) 
(d. 1586 and 1587) in Dolní Studénky (Fig. 46). In these cases, depicting more people in a single slab may be an expression of the psychological and social characteristics of the persons or to indicate a modern family approach. ${ }^{55}$

The manifestation of family relationships led to the fact that the family members, not only married couples, but grandparents, adult children and other relatives were often depicted in a group forming one unit. The tomb monuments in some cases reached rather large dimensions, such as in Klimkovice, Štáblovice, Stará Ves pod Ondřejnicí, Opava. At the end of the sixteenth century, the use of unified architectural framing for joining a number of tombstones of family members and their relatives made by various authors into one unit was no exception (Fig. 47). In the choirs of churches or burial chapels, monumental 'memorial galleries' were created for members of Moravian and Silesian families. At the same time, the above examples also indicate that many solitary tombstones today are often remnants of original units formed by aedicular architectural frameworks with inscription boards, coat of arms and possibly other accessories.

The figural tombstone production in Moravia and Czech Silesia in the last third of the sixteenth century shows in many examples a high quality of execution and is in some cases commensurate with the best preserved Prague works of the Mannerism of the period of Rudolf II, exceeding it by the number. ${ }^{56}$ Its distinctive nature is underlined by a certain traditionalism, but also by an emphasis on life-portrait and whole-figure depiction. It is made in a more intimate position, even if compared to the work of the surrounding countries. However, comparability is often only qualitative, not typological.

In the register of Moravian figural monuments, the frequency of occurrence seemed to be dominated by a gravestone or vertical wall tombstone, which was loosely tied to the funeral under the church floor or into the crypt. Tombs with the character of a 'gisant' can be found only rarely, for example the tombstone of Adam Štolbašský of Doloplazy in Olomouc, but also the slab of Znata of Lomnice (d. 1556) in Velká Bíteš. Both of the Hlučín figural sepulchres of Štěpán Bruntálský of Vrbno (d. 1567) and Marta of Žerotín (d. 1572) were conceived as cover slabs for tombs.

The Moravian and Silesian environment used rather rarely a type of 'priant' with a kneeling figure, such as in Bartošovice tombstone of Kateřina Supovna of Fulštejn (d. 1583) (Fig. 33), and it is missing entirely a tombstone with a semi-recumbent figure -

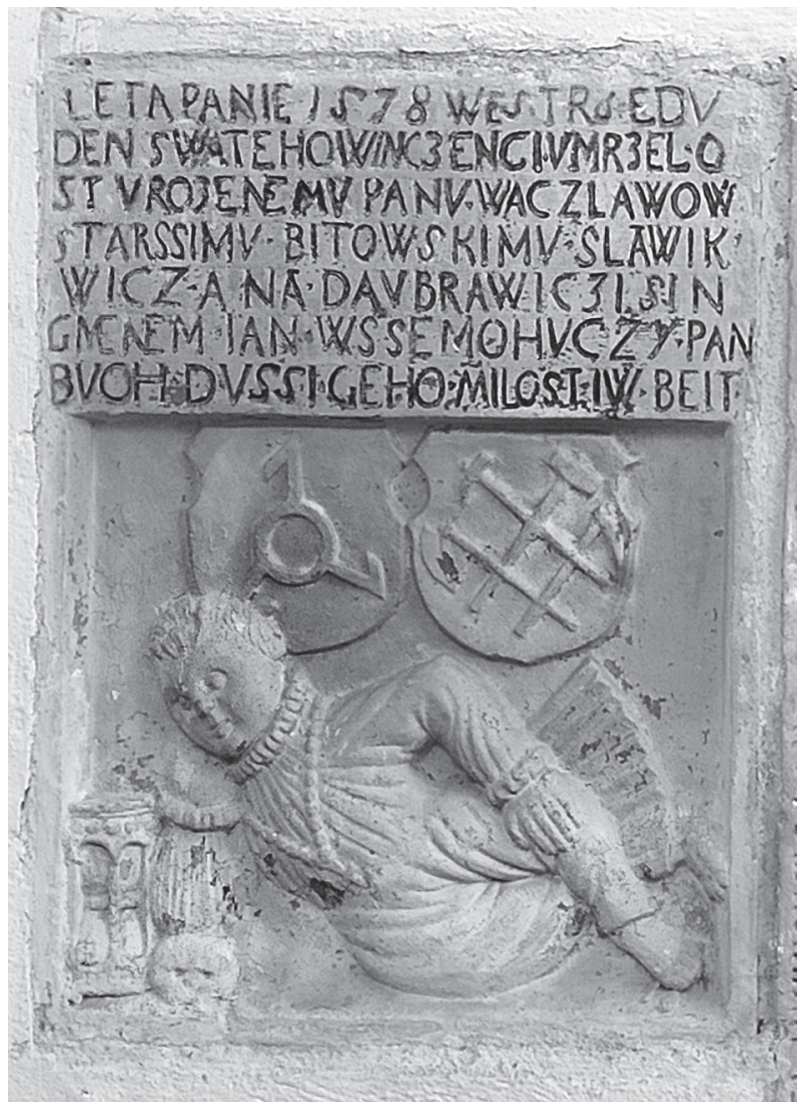

Fig. 48. Unknown master: tombstone of Jan Bítovský of Slavíkovice (d. 1578). Moravičany, Church of the Assumption of the Virgin Mary (photo: Petr Zatloukal)

the so-called 'statue accoudée' or 'sansovino' -, whose Renaissance type was revived at the beginning of the sixteenth century by sculptor Andrea Sansovino on tombstones in the choir of the church of Santa Maria del Popolo in Rome, ${ }^{57}$ and which became particularly popular in Poland. The children's memorial of Jan Bítovský of Slavíkovice (d. 1578) in Moravičany can be considered a diminished response to the 'Sansovino' tombstone (Fig. 48). A remarkable but unique monument that reveals the conceptual polarity arising from the discrepancy between depicting a recumbent figure from above and the vertical placement of the slab in the wall architectural framework is the sepulchre of Kateřina Drnovská of Drnovice (d. 1621), the wife of Hanuš Zdislav of Heissenstein in the parish church in Rájec nad Svitavou (Fig. 49).

The period shifts in the customs and mentality of the clients can also be observed in the character of the tombstones' inscriptions most commonly circulating in the areas of the tombstone edge mouldings (circular writing) or placed on more or less separate panels. Medieval Latin was gradually replaced by national languages, Czech and German. Initially, the 


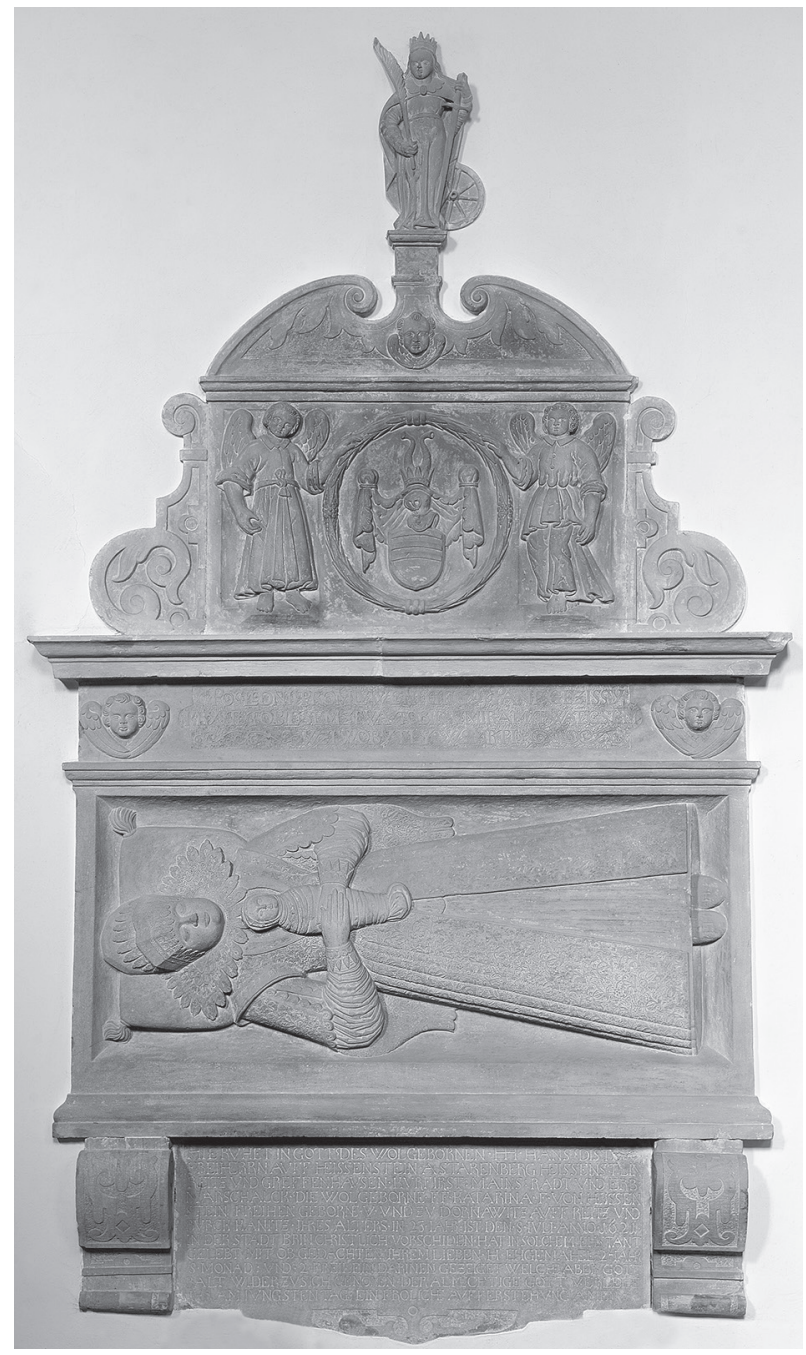

Fig. 49. Unknown master: tombstone of Kateřina Drnovská of Drnovice, the wife of Hanuš Zdislav of Heissenstein

(d. 1621). Rájec nad Svitavou, All Saints Church (photo: Petr Zatloukal)

inscriptions were concise and included in addition to the name of the deceased, also the name of the spouse (or the father), in particular the date of death; given more frequently by church holidays and the invocation. Gradually, the texts were expanded to include data indicating the hour of death, age of the deceased and more precise specification of the property by listing their dominion. Family relations and personal representation are also underlined by nominal references to the clients of the monument, such as on the tombstones of Václav senior Bítovský of Slavíkovice (d. 1582) in Moravičany or Estera Syrakovská of Pěrkov with her daughter Alina (d. 1589) in Dolní Studénky, where the message takes on a deeply emotional tone, expressing the sadness of the husband and father over the loss of his loved ones. Family and genealogical ties are recalled, for example by a list of surviving adult children on the coat of arms of lady Marta (d. 1564), the first wife of Matyáš Žalkovský of Žalkovice in Dobromilice. That allows us to determine the time of its implementation in the 1590s, together with the tombstone of her husband, that is, several decades after Marta's death.

Inscription texts also increasingly contain information regarding the social status of the deceased, including a list of offices and functions at the court or in the provincial administration. Such "verbose" biographical inscriptions can be found, for example, on the tombstones of Václav Berka of Dubá and Lipý (d. 1575) in Prague (Fig. 25) or Wolf Dietrich of Hardek (d. 1564) in Letovice (Fig. 14), the commission of which was made by the wives of the deceased, in the first case by Alena Meziříčská of Lomnice and Velké Meziřičí, and in the second by Regina Fuggerová, the daughter of the Augsburg banker and entrepreneur Anton Fugger.

From the 1560s onwards, the tombstones of the deceased Protestants became iconographically characterised by the use of biblical, especially Old Testament quotes, which were frequently repeated and had a didactic and religious function. It is noteworthy, however, that, the Old Testament quotation from the Wisdom Book of Job, Chapter XIX, is not only noticeably registered on the tombstones of the Protestant Žerotín family in Napajedla and Proček Morkovský of Zástřizl in Boskovice, but surprisingly also on the Mohelnice tombstone of the bishop's scribe Jakub Haladi (d. 1563, dated 1567) (Fig. 50).

Humanistic stylisation of inscription texts appeared in Moravia early in the late fifteenth century in a circle centred around bishop Stanislav Thurzo (eps. 1497-1540), for example on the memorial monument of Arnošt Kužel of Žeravice (dated 1524) (Fig. 9) or on the tombstone of Jan Lhotský of Ptení in Prostějov (d. 1533). ${ }^{58}$ Outside this environment, rather simple traditional formulations were used. In the second half of the sixteenth century, with the dissemination of humanist education Latin was returning on tombstones, and inscriptions were often verbose and sometimes versed. The high cultural demands of the Moravian aristocracy were manifested not only by the sightly architecture, but also by an exceptional celebration of the tombstone, as on the tombstone of Václav senior Morkovský of Zástřizl and Kunka of Korotín in Boskovice. A lengthy versed inscription - a poetic epitaph - was carved onto the postament, which was written on demand by the Calvinist theologian Theodor Beza in Geneva in 1601.59 
Within the so-called diffuse or multi-plicated monuments, ${ }^{60}$ the figural tombstones in the Renaissance were complemented by heraldic-inscription plates, in which the importance of identifying the deceased was reinforced by the coat of arms with an inscription. This type of tomb monument - used extensively and mainly individually since the Middle Ages - emphasised the renaissance glorification of the family or personality represented by the coat of arms most often in the spirit of humanistic connotations with the motif of laurel wreath or festoons and text placed on variously shaped tables or cartouches. A survey of Moravian and Silesian sepulchral monuments shows that the humanistic appreciation and self-confidence of the individual created, in an appropriate economic and spiritual climate, a space for the individual's remembrance, their position and the social ambitions of the family. Triumphal ideas were used in sepulchral art as a means of glorifying the earthly path of the deceased, and were also used to confirm the secular power and the dynastic upliftment of the nobility. ${ }^{61}$ Despite the selective character, the material processed up-to-date brings many new findings and partial conclusions that may contribute to deeper understanding of the overall picture of sepulchral tomb sculpture of the monitored area. The completed and on-going research has been conducted in an effort to help convincingly reconstruct the circumstances of the origin of sepulchral monuments and understand the dynamics of its transformation. At the same time, it hopes to contribute to the integration of Moravian and Silesian sepulchral works into contemporary cultural, social and creative contexts in the wider European level as well.

An indispensable goal of the research is also the need to revive the interest in these often severely damaged, degraded and neglected artefacts. These are important witnesses of history, irreplaceable traces of the private, social and cultural life of the place, and to contribute to their new art-historical appreciation and intensified monument protection. ${ }^{62}$

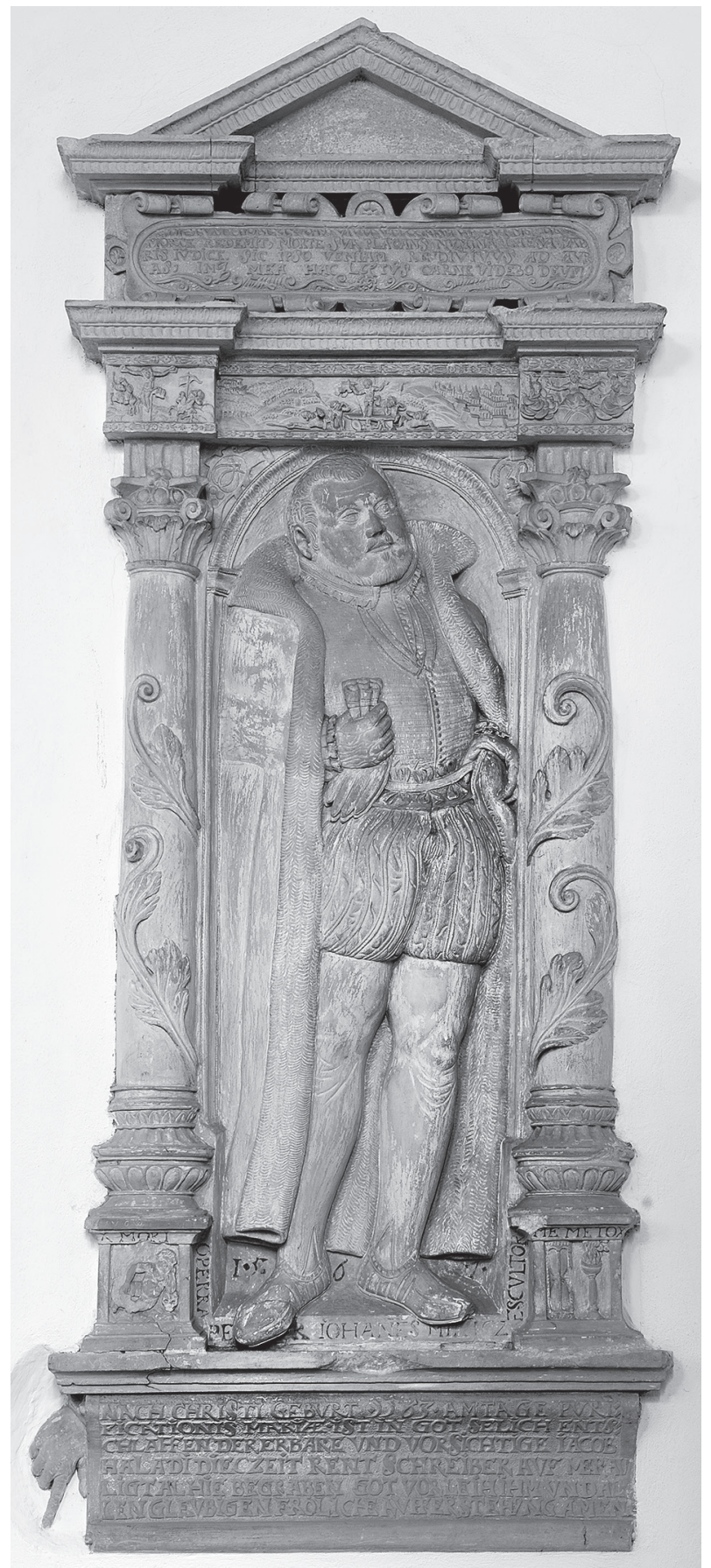

Fig. 50. Johannes Milicz: tombstone of Jakub Haladi, the scribe of the episcopal Mírov estate (d. 1563, dated 1567). Mohelnice, Church of St Thomas Becket of Canterbury (photo: Petr Zatloukal) 


\section{BIBLIOGRAPHY}

ARIÈs 1977 - ARIÈs, Philippe: L'homme devant la mort I. Le temps des gisants, Paris, 1977.

ArIÈs 2000 - ARIĖs, Philippe: Dějiny smrti I, Praha, 2000.

BreitenBACHER 1927 - BreitenBACHER, Antonín: Epitaf olomouckého biskupa Marka Kuena (1553-1565), Časopis Vlasteneckého spolku musejního v Olomouci XXXVIII. 1927. 98-101.

Burger 1904 - BuRGER, Fritz: Geschichte des florentinischen Grabmals von den ältesten Zeiten bis Michelangelo, Strassburg, 1904. 273.

Chadraba 1994 - Chadraba, Rudolf (rec.): Hlobil, Ivo - Petrư, Eduard: Humanismus a raná renesance na Moravě. Academia, Praha, 1992, Umění XLII. 1994. 179.

Chastel 1951 - CHAStel, André: La glorification humaniste dans les monuments funéraires de la Renaissance, in Chastelli, Enrico (ed.): Umanesimo e scienza politica, Atti del Congresso Internazionale di Studi Umanistici a Roma - Firenze 1949, Milano, 1951. 477-485.

Chlíbec 1980 - ChlíBec, Jan: Pozdně gotická a raně renesanční plastika na Olomoucku, in Historická Olomouc a její současné problémy III. Sborník referátů z celostátniho sympozia konaného v Olomouci ve dnech 16. - 19. 6. 1980, Olomouc, 1980. 83-91.

Denzler 1973 - Denzler, Max: Ewige Anbetung, in Reallexikon zur deutschen Kunstgeschichte VI, Stuttgart, 1973. 572-600.

ERICHSEN 1989 - ERICHSEN, Johannes: L’Extraordinario Libro di Architettura. Note su un manoscritto inedito, in Thoenes, Christof (ed.): Sebastiano Serlio. Sesto Seminario Internazionale di Storia dell Architettura. Vicenza 31 agosto - 4 settembre 1987, Vicenza, 1989. 190-195.

FEHR 1961 - FEHR, Götz: Benedikt Ried, Ein deutscher Baumeister zwischen Gotik und Renaissance in Böhmen, München, 1961.

Gurst-Hoyer-Ullmann 1989 - Gurst, Günter - Hoyer, Siegfried - UlLmann, Ernst et al. (eds.): Lexikon der Renaissance, Leipzig, 1989. 600.

Halama 2003 - Halama, Jindřich: Sociální učení českých bratř́ 1464-1618, Brno, 2003. 186.

Halm 1927 - Halm, Philipp Maria: Studien zur süddeutschen Plastik. Altbayern und Schwaben. Tirol und Salzburg II, Augsburg-Köln-Wien, 1927. 118 a n.

HLobil 1974 - HLoBiL, Ivo: Raně renesanční epitaf Johanna Eibenstocka v Olomouci, Vlastivědný věstník moravský XXVI. 1974. 307-311.

HLobil 1999 - Hlobil, Ivo: Sepulchrální skulptura, in HLobil, Ivo - PerưTKA, Marek (eds.): Od gotiky $k$ renesanci. Výtvarná kultura Moravy a Slezska 1400 - 1550 III. Olomoucko, Olomouc, 1999. 366-384.

Hlobil-Petrů 1992 - Hlobil, Ivo - Petrů, Eduard: Humanismus a raná renesance na Moravě, Praha, 1992.

Hlobil-Petrů 1999 - Hlobil, Ivo - Petrů, Eduard: Humanism and the Early Renaissance in Moravia, Olomouc, 1999.

HRejSA 1938 - HRejSA, Ferdinand: Luterství, kalvinismus a podobojí na Moravě před Bílou horou, Český časopis historický, 44. 1938. 296-326.

HRuBÝ 1922 - HRUBÝ, František: Moravská šlechta r. 1619, její jmění a náboženské vyznání, Časopis matice moravské 46. 1922. 133-134.
HRUBÝ 1934-1935 - HRuBÝ, František: Luterství a kalvinismus na Moravě před Bílou horou, Český časopis historický 40. 1934. 265-309; 41. 1935. 1-40, 237-268.

HRUBÝ 1970 - HRuBÝ, František: Etudiants tchèques aux écoles protestantes de l' Europe occidentale a la fin du $16^{e}$ et au début du $17^{e}$ siècle. Documents péparés pour l' édition par URBÁNKOVÁ-HRUBÁ, Libuše, préface par ŠindELÁř Bedřich, Brno, 1970.

INDRA 1966 - INDRA, Bohumír: K renesančnímu stavitelství na severovýchodní Moravě a ve Slezsku. Pramenné zprávy o vlašských a domácích stavitelích a kamenících do 30leté války, Časopis Slezského muzea v Opavě, Acta Musei Silesiae. Série B. Vědy historické XV. 1966. č. 2, 128-148.

INDRA 1983 - INDRA, Bohumír: Maliři, řezbáři a sochaři v Olomouci 1500-1650 (Biografický slovník), Umění XXXI. 1983. 73-80.

JAKUBEC 2003 - JAKUBEC, Ondřej: Kulturní prostředí a mecenát olomouckých biskupư potridentské doby, Olomouc, 2003.

JAKUBEC 2007 - JAKUBEC, Ondřej (ed.): Ku věčné památce, Malované renesanční epitafy v českých zemích, Muzeum umění Olomouc, Arcidiecézní muzeum, (exhibition catalogue), Olomouc, 2007.

JAKUBEC 2016 - JAKUBEC, Ondřej: Kde jest, ó smrti, osten tvioj? Renesanční epitafy v kultuře umírání a vzpomínání raného novověku, Brno, 2016.

JAKubec-Waisser 2015 - Jakubec, Ondřej - Waisser, Pavel: Mauzoleum Zachariáše z Hradce na zámku v Telči a jeho výzdoba v kontextu renesančních zámeckých kaplí, Opuscula Historiae Artium 64. 2015. 2-31.

JANSEN 1989 - JANSEN, Dirk Jacob: Jacopo Strada editore del Settimo Libro, in Thoenes, Christof (ed.): Sebastiano Serlio. Sesto Seminario Internazionale di Storia dell Architettura. Vicenza 31 agosto - 4 settembre 1987, Vicenza, 1989. 207-215.

KRAMÁŘ 1998 - KramáŘ, Vincenc: Zpustošení Chrámu svatého Vita v roce 1619, Fontes Historiae Atrium VI, k vydání připravil ŠronĚK, Michal, Praha, 1998. 55 a n.

KRČÁLOVÁ 1974 - KRČÁLOVÁ, Jarmila: Centrální stavby české renesance, Praha, 1974.

KROPÁČEK 1972 - KROPÁČEK, Jiří: Triumfální motivy $\mathrm{V}$ počátcích renesančního umění v Záalpí, Umění XX. 1972. 3, 268-276.

LiEDKE 1976 - LIEDKE, Volker: Die Baumeister- und Bildhauerfamillie Rottaler (1480-1533), Ars Bavarica, Archivalische Jahrbuch für Bauforschung und Kunstgeschichte in Bayern Band 5/6, München, 1976. 315-321.

LỐVEI 2006 - LÓVEI, Pál: Künstlerische Beziehungen in der Grabmalkunst der westlichen und nordwestlichen Gebiete des Königreichs Ungarn im Spätmittelalter, in Galéria - Ročenka SNG, 2004-2005, Bratislava, 2006. 123-138.

Maliva 1984 - Maliva, Josef: Mohelnický epitaf matky Valentina Nigra, in Severní Morava. Vlastivědný sbornik 48, Šumperk, 1984. 31-37.

Müller 2004 - MÜller, Karel: Snahy o evidenci sepulkrálních památek v českém Slezsku od konce 16. do konce 20. Století, in PRIX, Dalibor - ROHÁČEK, Jiří (ed.): Epigraphica E Sepulcralia I, Sborník přispěvkủ ze zasedání 
$k$ problematice sepulkrálních památek, pořádaných Ústavem dějin umění AV ČR v letech 2000-2004, Praha, 2005. 131-145.

MysliveČKová 1973 - MysliveČKovÁ, Hana: Ornament na raně renesančních kamenických památkách olomoucké oblasti (thesis, Faculty of Arts, Palacký University Olomouc), 1973.

MysliveČKOVÁ 1992 - MysLiveČKOVÁ, Hana: Humanistický náhrobek portrétní na Moravě a jeho misto $v$ kontextu domácí a evropské renesanční funerální plastiky (PhD dissertation, Faculty of Arts, Masaryk University), Brno, 1992.

MysliveČKovÁ 1997 - MysliveČKOVÁ, Hana: Renesanční polofigurové náhrobní a komemorativní památníky na Moravě. Vlivy italského humanismu a renesance v moravské náhrobní sochařské tvorbě. Vlastivědný věstník moravský 49. 1997. 2, 158-166.

MysliveČKOVÁ 1998 - MYsLiveČKOVÁ, Hana: Náhrobek „zakladatele olomoucké univerzity“ biskupa Viléma Prusinovského z Víckova, in Historická Olomouc a její současné problémy XI, Olomouc, 1998. 105-114.

MYsLiveČKOVÁ 2005 - MYsLiveČKOVÁ, Hana: Manýristický bronzový náhrobek Jana Bedřicha Breinera v kostele Panny Marie Sněžné v Olomouci, Průzkumy památek XII. 2005. 1, 110-117.

MysliveČKová 2006 - MysliveČKová, Hana: Sepulkrální tvorba olomoucké oblasti v období počátků renesance a proměny jejího kamenosochařského zpracování, Vlastivědný věstník moravský LVIII. 2006. 2, 137-153.

MysliveČKovÁ 2006 - MrsliveČKovÁ, Hana: Příklady pozdně renesanční komemorativní reprezentace $\mathrm{v}$ rytířské rodině Zástřizlů na Moravě, Umèní LIV. 2006. 177-186.

MYsLiveČKOVÁ 2007 - MYsLiveČKOVÁ, Hana: Epitafy v renesanční sepulkrální sochařské tvorbě Moravy a eského Slezska, in JAKUBEC, Ondřej (ed.): Ku věčné památce, Malované renesanční epitafy v českých zemích, Muzeum umění Olomouc, Arcidiecézní muzeum, (exhibiton catalogue), Olomouc, 2007. 73-81.

MysLIVEČKOVÁ 2011 a - MYsLiveČKOVÁ, Hana: Náhrobní deska Jindřicha Supa z Fulštejna ( $† 7$. ervna 1538) v kostele sv. Martina v Bohušově, in ROHÁČEK, Jiří (ed.): Epigraphica E Sepulcralia III, Sborník př́spěvků ze zasedání k problematice sepulkrálních památek, pořádaných Ústavem dẽjin umění AV ČR v letech 2008-2010, Praha, 2011. 303-322.

MysliveČKová 2011b - MysliveČKovÁ, Hana: Náhrobek Kašpara Pruskovského z Pruskova Hradec nad Moravicí, farní kostel sv. Petra a Pavla, in ŠopÁk, Pavel (ed.): Pamět' Slezska, Památky a pamět'ové instituce českého Slezska v 16.-19. století, Opava: Slezské zemské muzeum Opava, 2011. 56.

MysliveČKOVÁ 2013 - MysLiveČKovÁ, Hana: Mors ultima linea rerum, Pozdně gotické a renesanční náhrobní monumenty na Moravě a v českém Slezsku, Olomouc, 2013.

MysliveČKovÁ 2016 - MYsLIVEČKOVÁ, Hana: Těšínské sepulkrálie z dílny Mistra náhrobki̊ v Sedlnicích, in Mezihoráková, Klára (ed.): Památky Těšinského knižectví, Praha, 2016. 65-79.

MysliveČKovÁ-Müller 2011 - MysLiveČKovÁ, Hana - MüLLER, Karel: Sepulchrální památky v kostele sv. Martina, in KozÁk, Petr - Prix, Dalibor - Zezula, Michal a kolektiv: Kostel sv. Martina v Bohušově, Ostrava, 2011. 365-398.
MysliveČKOVÁ-Müller (in print) - MYsLiveČKOVÁ, Hana MÜlLER, Karel: The Tombstone of the Knight Kryštof Kropá of Nevědomí in the Hungarian National Museum in Budapest. A Contribution on the Style Syncretism of the first half of the $16^{\text {th }}$ Century in Moravia, in Epigraphica \& Sepulcralia (in print)

NovÁKová [1952?] - NováKová, Miroslava: Renesanční světský figurální náhrobek moravský (1520-1620). Př́spěvek $k$ dějinám renesanční plastiky na Moravě (unpublished thesis, Jan Evangelista Purkyně University), Brno, s. d. [1952?]

Patzelt 1993 - Patzelt, Edwin: Ein Epitaph des Eichstätter Bildhauers Loy Hering in Leutschau/Zips, Historischer Verein Eichstätt. Sammelblatt 86. 1993. 63-65.

POJSL 2005 - PojsL, Miloslav: K poátkům soupisu sepulkrálních památek na Moravě, in PRIX, Dalibor - ROHÁČEK, Jiří (eds.): Epigraphica \& Sepulcralia I, Sborník příspěvkư ze zasedání $k$ problematice sepulkrálních památek, pořádaných Ústavem dějin umění AV ČR v letech 20002004, Praha, 2005. 147-155.

PojsL 2006 - PojsL, Miloslav: Sepulkrální památky na Moravě a ve Slezsku do roku 1420, Olomouc: Univerzita Palackého, 2006. (Monumenta Moraviae et Silesiae Sepulcralia I)

RADOVÁ 1967 - RADOVÁ, Milada: Sjezd kameníků v Annaberku v roce 1518, Architektura ČSR XXVI. 1967. 4, 187-188.

Ritoók 2018 - Ritoók, Ágnes: Náhrobný kamen̆ Kryštofa Kropáča z Nevědomí a na Bzenci, Záhorie XXVII. 4, 2018. 2-6.

SCHÉle 1965 - SCHÉle, Sune: Cornelis Bos. A Study of the Origins of the Netherland Grotesque, Stockholm, 1965. (Acta Universitatis Stockholmiensis, Stockholm Studies in History of Art 10)

SChulters 2003 - SchUlters, Lothar: Plastik vom Ende des schönen Stils bis zum Beginn der Renaissance, in RosenAuer, Artur (ed.): Geschichte der bidenden Kunst in Österreich III. Spätmittelalter und Renaissance, MünchenBerlin-London-New York, 2003.

SPICER 1992 - SPICER, Joneath: The Renaissance Elbow, in Bremmer, Jan - Roodenburg, Herman (eds.): A Cultural History of Gesture. From Antiquity to the Present Day, New York, 1992. 84-128.

Urbanová-Remešová [1949?] - URBAnOVÁ-RemeŠOvÁ, Věra: Pražské pozdnè renesanční náhrobky (1570-1620), (thesis, Faculty of Arts, Charles University), Praha, s. d. [1949?]

VACKOVÁ 1976 - VACKOVÁ, Jarmila: O symbolice triumfu v naší a v zahraniní literatuře, Umění XXIV. 1976. 4, 377-382.

VÁlKA 1993 - VÁLKA, Josef: Moravská aristokracie na přelomu 16. a 17. století, in Opera historica 3, Sborník katedry historie Pedagogické fakulty Jihočeské univerzity, České Budějovice, 1993. 155-165.

VÁlKa 1996 - VÁlKA, Josef: Dějiny Moravy 2. Morava reformace, renesance a baroka, Brno, 1996 (Vlastivěda moravská. Země a lid. Nová řada, 6)

VAnCSA 2003a - VAncsa, Eckart: Wien I., Portal der Salvatorkirche (1515-1519), in RosenaUer, Artur (ed.): Geschichte der Bildenden Kunst in Österreich: Spätmittelalter und Renaissance, Wien, 2003. 270.

VANCSA 2003b - VANCSA, Eckart: Wiener Neustadt (NÖ), Portal des ehemaligen Zeughauses, 1524, in RosenAUER, Artur (ed.): Geschichte der Bildenden Kunst in Österreich: Spätmittelalter und Renaissance, Wien, 2003. 271. 
VLČEK 2004 - VLČEK, Pavel: Beránek (Pražák) Jindřich, in VLČEK, Pavel: Encyklopedie architektů, stavitelü, zedníkůa a kameníků v Čechách, Praha: Academia, 2004. 60.

Weisbach 1916 - Weisbach, Werner: Triomfi, Berlin, 1919. WinTER 1909 - Winter, Zikmund: Řemeslnictvo a živnosti 16. věku v Čechách (1526-1620), Praha, 1909.
ZAPLETAL 1967 - ZAPLeTAL, Florian: Bronzový renesanní epitaf v Olomouci z r. 1566, Vlastivědný věstník moravský 19. $1967.80-82$.

ZEMEK 1948 - ZemeK, Metoděj: Náhrobky v metropolitním kostele sv. Václava v Olomouci, Praha, 1948 (offprint from the journal Rodokmen III. 1948)

\section{NOTES}

${ }^{1}$ The article was written within the grant funded by Palacky University Olomouc with the reference no. of IGA PdF_2019_009 titled Renaissance Sepulchral Production in Moravia in the Central European Context. Research - its Presentation - Application in Educational Practice.

2 PojsL 2005, 147-155.

3 MÜlLER 2004, 131-145.

${ }^{4}$ The manuscript is deposited in Moravský zemský archiv $v$ Brně [the Moravian Regional Archive in Brno], the G 50 collection, and the Augustin Kratochvíl personal collection.

${ }^{5}$ POJSL 2006.

${ }^{6}$ NovÁKOVÁ [1952?].

${ }^{7}$ CHLíBec 1980, 83-91.

${ }^{8}$ Mainly HLobil-Petrư 1992, in an altered version also HLobil-Petrů 1999; HLobil 1999, 366-384.

${ }^{9}$ JAKUBEC 2007; JAKUBEC 2016

${ }^{10}$ MysliveČKOVÁ 2013. For the needs of European comparative studies, it seems useful to present the results of this research in the current context, also because the book has been supplemented for technical reasons only by a brief English summary. The publication provides a detailed bibliography on this issue that could not be included in this study.

${ }^{11}$ The author uses the term gravestone only to denote a plate that has survived in its original location and covers or demonstrably used to cover the grave in the floor. For sepulchres that were obviously conceived as vertical, or for those whose original location is unknown, the author uses the broader term tombstone. The term epitaph then refers to a devotional and commemorative artefact that does not relate directly to a grave but was created to commemorate the deceased. The most common components of such a monument were religious scenes, depictions of the deceased and family members, and inscription.

12 Concerning stone-sculpting techniques for relief tombstones, it can be simply said that the relief technology of a Gothic-trained artist is characterised by its immersion in a stone slab, whose mass is being removed into the dept below its upper level, referred to as relief en creu, relief dans le creux. As the reception of Renaissance influences advances, there is an attempt at a new spatial arrangement, grading of plans and masses, which in Renaissance Italy led to a completely new way of conception of relief, referred to as rilievo schiacciato. It was enriched by the gentle gradation of the upper surfaces by the artists of the early quattrocento Lorenzo Ghiberti and Donatello. On relief e.g. GURST-HoyerUlLMANn 1989, 600.

13 Patzelt 1993.

${ }^{14}$ This is pointed out by the portal of the town hall chapel of St Salvator in Vienna and the portal of the former imperial armoury in Wiener Neustadt, see VANCSA 2003a; VANCSA 2003b.
15 At this time, an influx of Italian craftsmen from the Italian-Swiss border can be seen in our countries, see INDRA 1966; INDRA 1983.

${ }^{16}$ RADOVÁ 1967, 187-188. In Görlitz, for example, Ried's pupil Wendel Roskopf, who also worked in Wroclaw, became the town's construction master.

17 See FEHR 1961.

${ }^{18}$ Manneristic thelamons with human feet, such as those found in the works of the Master of Žerotin's Tombstones in Napajedla and Černíkovice, can be found in both Cornelis Bos (cf. SCHÉle 1965, Figs. 71, 84, 96) and Sebastiano Serlio (cf. ERICHSEN 1989, 190-195, Fig. 4).

${ }^{19}$ The imperial court 'engineer' and antiquarian Jacopo Strada bought Serlio's manuscripts that had not been published till then and became the publisher of his work titled Settimo Libro (1575). cf. JANSEN 1989.

${ }^{20}$ For further details on their existence, see ZEMEK 1948 , $7-13$

${ }^{21}$ This much discussed opinion was introduced into literature by NovÁKOVÁ [1952?], 36 and the following. It was further elaborated on by Ivo Hlobil in the publication HLOBIL-PETRŮ 1992, 202.

${ }^{22}$ However, this designation is used in literature consensually. See MysLIVEČKOVÁ 2006.

23 POJSL 2006.

${ }^{24}$ Ivo Hlobil introduced to the specialised literature the designation of Eibenstock's tombstone as an epitaph, cf. HLOBIL 1974.

${ }^{25}$ Hlobil 1974, 309; Chlíbec 1980, 83-91; Maliva 1984, 31-37; Hlobil-Petrư 1992, 195 and the following; HlobilPetrư 1999, 215 and the following; HLOBil 1999, 372, 375 , 377.

${ }^{26}$ For further details on Stephan Rottaler and the circumstances of his work, see e.g. HALM 1927, 118 and following, and mainly LIEDKE 1976, 315-321.

27 MYSLIVEČKOVÁ 2013, 64-65.

${ }^{28}$ MYsLiveČKOVÁ 1973, 56, 59.

${ }^{29}$ Cf. Winter 1909, 95-96. Winter mentions him as an outstanding stonemason of the Rudolf II era and considers him, probably erroneously, to be the author of Krocin's fountain (1591). This master, famous for his work, was a guild-master of the stonemason's and bricklayer's guild between 1599-1606: VLČEK 2004, 60

${ }^{30}$ MysLiveČKová 2013, 245-260.

${ }^{31}$ VÁLKA 1996, 61; JAKUBEC 2003

32 Such an example was certainly an extraordinary, ambitious project of the funeral Chapel of All Saints, which was built on the premises of the chateau in Tel in the 1570s and 1580s commissioned by Zachariáš of Hradec after the death of his first wife. cf. JAKUBEC-WAISSER 2015. 
${ }^{33}$ Lóvei 2006, 135; Ritoók 2018; MysLiveČKOVÁ-MüLleR (in print).

${ }^{34}$ The tombstone, whose composition has long been a model for many sepulchres of the Renaissance era, is the late Gothic Prostějov tombstone of Johana of Kravaře (d. 1495), whose model could be the tombstone of Eleonora Portugal (d. 1467), the wife of Emperor Frederick III in Wiener Neustadt, Austria, a work attributed to the workshop of Nicholas Gerhaert, cf. SCHULTERs 2003, 321-322.

${ }^{35}$ Cf. e.g. WeISBACH 1916, 96 and the following; KROPÁČEK 1972; VACKOVÁ 1976.

36 VÁLKA 1993, 159.

37 VÁlKa 1996, 14; HrubÝ 1934-1935; HreJSA 1938.

38 HrubÝ 1922, 133-134; HrubÝ 1970.

${ }^{39}$ VÁLKA 1996, 16-17. On the Relation of Reformed Churches to Artefacts, see e.g. KRAmÁř 1998, 55 and the following.

${ }^{40}$ Chastel 1951, 479.

${ }^{41}$ MysliveČKová 2007, 73-81.

42 CHLíBEC 1980.

${ }^{43}$ KrČÁLOVÁ 1974, 32-33 ranks it among the most important buildings of the sixteenth century not only in this country, but also in the whole of Central Europe.

${ }^{44}$ MysliveČKovÁ 1992; MYsLiveČKovÁ 1997.

45 ARIĖs 1977, 250; ARIĖs 2000, 311; For more details on the tombstone, see MYSLIVEČKOVÁ $2011 \mathrm{~b}$.

${ }^{46}$ VÁlKa 1996, 15; Chadraba 1994, 179.
${ }^{47}$ DenZler 1973.

${ }^{48}$ A relatively large number of children's tombstones or depictions of children in adult sepulchres have been preserved. The scope of the presented research included only those tombstones related to the production of the observed workshop groups. A systematic survey of children's Renaissance and Manneristic tombstones has not been carried out yet.

49 SPICER 1992, 84-128.

50 KROPÁČEK 1972; WeISBACH 1916, 96 and the following; VACKOVÁ 1976.

${ }^{51}$ MysliveČKová 2011a; MysliveČKovÁ-Müller 2011.

52 BREITENBACHER 1927; ZAPLETAL 1967.

${ }^{53}$ MysliveČKovÁ 1998.

54 MysLiveČKOVÁ 2005.

55 Halama 2003, 186

${ }^{56}$ UrbanOVÁ-REMEŠOVÁ [1949?] dealt with the Prague's tombstone works of this period in an unsurpassed manner. 57 See BuRGER 1904, 273.

58 Inscriptions of preserved tombstones in the Cathedral of St Wenceslas in Olomouc are presented by ZEMEK 1948, passim.

${ }^{59}$ For further details, see MYsLIVEČKOVÁ 2006.

${ }^{60}$ ARIĖs 1977, 250; ARIĖs 2000, 311

${ }^{61}$ Chastel 1951, 479.

62 Translated by Jana Jiroutová. 